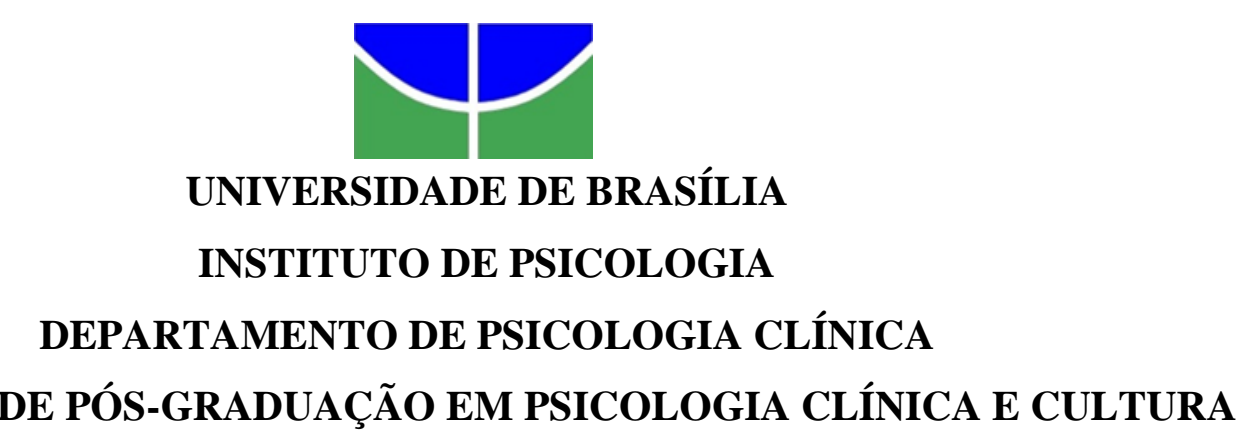

PROGRAMA DE PÓS-GRADUAÇÃO EM PSICOLOGIA CLÍNICA E CULTURA

SAÚDE MENTAL E GÊNERO EM UM CAPS II DE BRASÍLIA: CONDIÇÕES SOCIAIS, SINTOMAS, DIAGNÓSTICOS E SOFRIMENTO PSÍQUICO

IONEIDE DE OLIVEIRA CAMPOS

BRASÍLIA - DF 
UNIVERSIDADE DE BRASÍLIA

INSTITUTO DE PSICOLOGIA

DEPARTAMENTO DE PSICOLOGIA CLÍNICA

PROGRAMA DE PÓS-GRADUAÇÃO EM PSICOLOGIA CLÍNICA E CULTURA

\title{
SAÚDE MENTAL E GÊNERO EM UM CAPS II DE BRASÍLIA: CONDIÇÕES SOCIAIS, SINTOMAS, DIAGNÓSTICOS E SOFRIMENTO PSÍQUICO
}

\author{
Ioneide de Oliveira Campos
}

Tese apresentada ao Instituto de Psicologia da Universidade de Brasília - Programa de PósGraduação em Psicologia Clínica e Cultura como requisito parcial para obtenção do título de Doutora em Psicologia.

Orientadora: Prof. Dra. Valeska Maria Zanello de Loyola

$$
\text { BRASÍLIA - DF }
$$


Ficha catalográfica elaborada automaticamente, com os dados fornecidos pelo(a) autor(a)

Campos, Ioneide de Oliveira

Cs Saúde mental e gênero em um CAPS II de Brasília:

condições sociais, sintomas, diagnósticos e sofrimento psíquico / Ioneide de Oliveira Campos; orientador Valeska Maria Zanello de Loyola. -- Brasília, 2016.

$122 \mathrm{p}$.

Tese (Doutorado - Doutorado em Psicologia Clínica e Cultura) -- Universidade de Brasília, 2016.

1. saúde mental. 2. gênero. 3. condições sociais. 4. violências. I. Loyola, Valeska Maria Zanello de, orient. II. Título. 


\section{ESTE TRABALHO FOI REALIZADO NO INSTITUTO DE PSICOLOGIA - UNIVERSIDADE DE BRASÍlIA - PROGRAMA DE PÓS-GRADUAÇÃO EM PSICOLOGIA CLÍNICA E CULTURA SOB A ORIENTAÇÃO DA PROF. ${ }^{a}$ DR. ${ }^{a}$ VALESKA MARIA ZANELLO DE LOYOLA}

Banca examinadora

Profa. Dra. Valeska Maria Zanello de Loyola - Presidente

Universidade de Brasília - UnB

Profa. Dra. Isabela Machado - Membro Interno

Universidade de Brasília - UnB

Prof. Dr. Wanderson Flor do Nascimento - Membro Externo

Universidade de Brasília - UnB

Prof. Dra. Mariana Cunha Pereira - Membro Externo

Universidade Federal de Goiás - UFG

Prof. Dra. Madge Porto - Membro Externo

Universidade Federal do Acre - UFAC

Prof. Dra. Sílvia Lordello - Membro Suplente

Universidade de Brasília - UnB

BRASÍLIA, MARÇO DE 2016 
Às mulheres deste estudo, e às que fazem parte da minha história:

à minha mãe Zilma, às minhas irmãs Ilce, Irê e Nilda, às sobrinhas Aninha e Cecília e à minha filha Julia. 


\section{AGRADECIMENTOS}

Agradeço a todas as pessoas que diretamente ou indiretamente contribuíram com este estudo, em especial à Equipe de Profissionais e aos Usuários/as do Centro de Atenção Psicossocial de Brasília. A todos, deixo meu agradecimento por meio dos fragmentos de uma música do cantor e compositor Gonzaga Jr. intitulada Caminhos do coração.

E aprendi que se depende sempre

De tanta, muita, diferente gente

Toda pessoa sempre é as marcas

Das lições diárias

De outras tantas pessoas

E é tão bonito quando a gente entende

Que a gente é tanta gente

Onde quer que a gente vá

E é tão bonito quando a gente sente

Que nunca está sozinho

Por mais que pense estar 
Campos, I. O. (2016). Saúde mental e gênero em um CAPS II de Brasília: condições sociais, sintomas, diagnósticos e sofrimento psíquico. 122 p. Tese (Doutorado em Psicologia Clínica e Cultura) - Instituto de Psicologia, Universidade de Brasília, Brasília.

\section{RESUMO}

As transformações do modelo de assistência em saúde mental no Brasil, impulsionadas pelo processo de Reforma Psiquiátrica, implicaram a criação de serviços substitutivos de atenção à saúde mental, discussões sobre rede de suporte social e de saúde, assim como demandas e necessidades de políticas públicas advindas desse processo. Entretanto, são prementes as discussões e estratégias de inserção das relações de gênero no contexto da saúde mental, como subsídio de compreensão dos papéis de gênero gendrados embutidos no conceito de sofrimento psíquico de homens e mulheres, ou seja, papéis marcados por especificidades de gênero na sociedade patriarcal. Assim, o objetivo geral deste estudo foi realizar uma leitura do sofrimento psíquico sob o enfoque das relações de gênero, a partir de dados sociodemográficos, dos sintomas e diagnósticos e sobre a vivência com o sofrimento de usuárias em um Centro de Atenção Psicossocial II de Brasília. Dessa forma, a presente tese está constituída por quatro artigos. O primeiro teve como objetivo discutir algumas concepções sobre loucura no Ocidente, ao longo dos processos de constituição e reestruturação do modelo de assistência psiquiátrica. Como a população deste estudo compõese basicamente de mulheres, buscou também resgatar a especificidade da relação entre mulheres e loucura, em uma perspectiva histórica, social e cultural e, por fim, abordou as relações de gênero como questão importante na Saúde Mental brasileira na atualidade. O segundo artigo foi baseado em estudo quantitativo, transversal e visou caracterizar, comparar e analisar o perfil sociodemográfico entre mulheres e homens no período de 2012 e 2013. Nos resultados observamos significativa presença feminina em comparação aos homens e evidenciamos características comuns entre os sexos, que reforçam a vulnerabilidade e desigualdades sociais. Fazem-se importantes projetos alternativos de trabalho e geração de renda e investimentos em políticas públicas transversais. O terceiro é um estudo qualiquantitativo, no qual se objetivou realizar uma leitura sobre os diagnósticos e sintomas, a partir de uma perspectiva de gênero e saúde mental. Os resultados demonstram prevalência de 
diagnósticos relacionados aos transtornos do humor em mulheres e, nos homens, de esquizofrenia, transtornos esquizotípicos e delirantes. Tais dados associados ao levantamento do perfil sociodemográfico e a análise dos dados dos prontuários, apontam para a medicalização e psiquiatrização da vida, sobretudo no caso das mulheres, cuja presença em episódios de violência chegou a 32,54\%. Por fim, a partir das narrativas de cinco mulheres, o quarto artigo tem como enfoque a compreensão da vivência do sofrimento psíquico, no que concerne, aos núcleos narrativos significativos, entre eles, o trabalho como vulnerabilidade atravessado pelo gênero e as relações familiares (relações conjugais, maternagem, com os pais e ascendentes), atravessadas pelas violências sofridas, física, sexual e psicológica. Os resultados demostram situações dolorosas e estigmatizadoras vivenciadas por mulheres, marcadas pelas violências. Concluímos, a partir da síntese dos quatro artigos, que o modelo em saúde mental no Brasil apresenta ainda um enfoque em intervenções centradas em sintoma-solução e inexiste uma agenda específica de gênero no cenário dos serviços públicos de saúde mental. Ainda, pela diferença populacional entre o quantitativo de mulheres e homens, concluímos que este CAPS II é um espaço da expressão subjetiva feminina. Apreende-se que o modelo de atenção psicossocial brasileiro pode não possibilitar um acolhimento adequado às mulheres em geral, se não qualificar as especificidades de gênero e suas interseccionalidades. Logo, a implantação de projetos alternativos de trabalho e geração de renda e também investimentos em políticas públicas transversais, como forma de subsidiar a atual Política de Saúde Mental Brasileira, fazem-se necessários.

Palavras-chave: saúde mental; gênero; condições sociais; mulheres, violências.

\begin{abstract}
The transformations of the model of mental health care in Brazil, driven by the process of Psychiatric Reform, has led to the creation of substitutive services of mental health attention, discussions about social and health support network, as well as the demands and needs of public policies resulting from this process. In the meantime, the discussions and integration strategies of gender relations in the context of mental health, such as understanding allowance of gendered gender roles embedded in the concept of psychic suffering of men and women,
\end{abstract}


i.e. roles marked by gender specificities in patriarchal society, are pressing. Thus, the aim of this study was to carry out a reading of psychological distress from the standpoint of gender relations, from socio-demographic data, symptoms and diagnosis and about the experience with the suffering of users in a Center of Psycho-Social Attention - CAPS II of Brasília. In this way, this thesis is constituted by four items. The first aimed to discuss some conceptions of madness in the West over the establishment of processes and restructuring of psychiatric care model. As the population of this study basically consists up of women, we also sought to rescue the specificity of the relationship between women and madness, in a historical, social and cultural perspective and finally approached gender relations as an important issue in the Brazilian Mental Health nowadays. The second article was based on a quantitative study, cross-sectional and aimed to characterize, compare and analyze the sociodemographic profile of women and men in the period of 2012 and 2013. The results observed significant presence of women compared to men and evidenced common characteristics between the sexes, which reinforce the vulnerability and social inequality. It is important to create and develop alternative projects of work and income generation and investment in cross public policy. The third article is a quantitative and qualitative study, which aimed to carry out a reading about the diagnosis and symptoms, from a gender and mental health perspective. The results showed prevalence of diagnoses related to mood disorders in women; and in men, schizophrenia, schizotypal and delusional disorders. Such data associated with the sociodemographic profile and analysis of data records point to the medicalization and psychiatrization of life, especially for women, whose presence in violence episodes has reached $32.54 \%$. Finally, from the narratives of five women, the fourth article has focus on understanding the experience of psychological distress, with respect the significant narrative nuclei, among them, work as vulnerability crossed by gender and family relations (relations marriage, mothering, with parents and ascendants), crossed by the violence suffered, physical, sexual and psychological. The results demonstrate painful and stigmatizing situations experienced by women, marked by violence. We conclude, from the synthesis of the four articles, that the mental health model in Brazil still has a focus on interventions concentrated on symptom-solution and there is not a specific gender agenda in the scenario of public mental health services. Also, due to the difference between the amount of women and men, we conclude that this CAPS II is a space of female subjective expression. It is inferred that the model of Psychosocial Attention Brazilian can not provide a suitable welcome for women in general, if not qualify the specifics of gender and its intersectionalities. Still, by the difference in population between the quantitative of women and men, we concluded that this CAPS II is 
a space of expression female subjective. Therefore, the implementation of alternative projects of work and income generation, as well as investments in cross public policy, in order to support the current Mental Health Policy Brazilian, becomes necessary.

Keywords: mental health; genre; social conditions; women; violences.

\section{RESUMEN}

Las transformaciones del modelo de atención de salud mental en Brasil, impulsadas por el proceso de Reforma Psiquiátrica implicaran la creación de servicios alternativos de atención de salud mental, discusiones sobre el apoyo social y de la salud, así como las demandas y necesidades de políticas públicas derivadas de este proceso. Sin embargo, son urgentes las discusiones y las estrategias de integración de las relaciones de género en el contexto de la salud mental, como la comprensión de asignación de los roles de género engendrados implícitos en el concepto de sufrimiento psíquico de los hombres y las mujeres, es decir, los roles marcados por las especificidades de género en la sociedad patriarcal. Por lo tanto, el objetivo de este estudio fue realizar una lectura de los trastornos psicológicos desde el punto de vista de las relaciones de género, a partir de datos sociodemográficos, los síntomas y el diagnóstico y la experiencia con el sufrimiento de las usuarias en un Centro de Atención Psicosocial II - CAPS de Brasília. Así, esta tesis está constituida por cuatro artículos. El primer tuvo el objetivo de discutir algunas concepciones de locura en Occidente sobre el establecimiento de procesos y reestructuración del modelo de atención psiquiátrica. A medida que la población de este estudio consiste básicamente por mujeres, también se trató de rescatar la especificidad de la relación entre las mujeres y la locura, en una perspectiva histórica, social y cultural y, finalmente, se acercó a las relaciones de género como un tema importante en la salud mental de Brasil hoy en día. El segundo artículo se basó en un estudio cuantitativo, transversal y tenía como objetivo caracterizar, comparar y analizar el perfil sociodemográfico de las mujeres y los hombres en el período 2012 y 2013. Los resultados mostraron importante presencia de las mujeres en comparación con los hombres, y lo demuestran características comunes entre los sexos, los cuales refuerzan la vulnerabilidad y la desigualdad social. Son importantes proyectos alternativos de generación de trabajo y ingresos y la inversión en la política pública transversal. El tercero artículo es un estudio 
cuantitativo y cualitativo, que tiene por objeto realizar una lectura sobre el diagnóstico y los síntomas, desde una perspectiva de género y la salud mental. Los resultados indican que la prevalencia de los diagnósticos relacionados con los trastornos del estado de ánimo en mujeres; y en hombres, esquizofrenia, trastornos esquizotípicos y delirantes. Tales datos asociados con el perfil sociodemográfico y análisis de los registros de datos apuntan a la medicalización y psiquiatrización de la vida, especialmente para las mujeres, cuya presencia en episodios de violencia ha alcanzado 32,54\%. Por último, a partir de las narrativas de cinco mujeres, el cuarto artículo se centra en la comprensión de la experiencia de los trastornos psicológicos, con respeto a los núcleos narrativos importantes, entre ellos, el trabajo como la vulnerabilidad atravesada por relaciones de género y de la familia (relaciones conjugales, la maternaje, con los padres y ascendentes), atravesadas por la violencia que sufren, física, sexual y psicológica. Los resultados demuestran situaciones dolorosas y estigmatizantes, experimentadas por mujeres, marcadas por la violencia. Llegamos a la conclusión a partir de la síntesis de los cuatro artículos que el modelo de salud mental en Brasil aún tiene un enfoque en las intervenciones centradas en los síntomas-solución y no existe un programa específico de género en el escenario de los servicios públicos de salud mental. Aún, por la diferencia de población entre el cuantitativo de las mujeres y de los hombres, llegamos a la conclusión de que este CAPS II es un espacio de expresión subjetiva femenina. Se infiere que el modelo de Atención Psicosocial brasileño no puede ofrecer una bienvenida adecuada a las mujeres en general, si no califica las especificidades de género y sus interseccionalidades. interseccionalidades. Por lo tanto, la implementación de proyectos alternativos de trabajo y generación de ingresos, así como las inversiones en políticas públicas transversales, como una manera de subvencionar la actual política de salud mental de Brasil, son necesarias.

Palabras-clave: salud mental; género; condiciones sociales; mujeres; violencias. 


\section{LISTA DE TABELAS}

\section{Tabelas referentes ao artigo 2}

Tabela 1 - Distribuição dos totais e percentuais da faixa etária, situação conjugal, escolaridade, religião e quantitativo de filhos, segundo sexo.

Tabela 2 - Distribuição dos totais e percentuais da situação de trabalho, renda familiar, benefícios e ocupação, segundo sexo.

\section{Tabelas referentes ao artigo 3}

Tabela 1- Prevalência dos diagnósticos definidos entre homens e mulheres, de acordo com a $\mathrm{CID} / 10$

Tabela 2 - Funções psíquicas alteradas entre homens e mulheres 


\section{LISTA DE SIGLAS}

\begin{tabular}{ll} 
CAPS & Centros de Atenção Psicossocial \\
CEP & Comitê de Ética em Pesquisa \\
CID & Classificação Internacional de Doenças \\
DF & Distrito Federal \\
DSM & Diagnostic and Statistical Manual of Mental Disorders (Manual de Diagnóstico \\
& e Estatístico dos Transtornos Mentais) \\
FCE & Faculdade de Ceilândia \\
HSVP & Hospital São Vicente de Paulo \\
HBDF & Hospital de Base do Distrito Federal \\
IBGE & Instituto Brasileiro de Geografia e Estatística \\
ICH & Instituto de Ciências Humanas \\
ISM & Instituto de Saúde Mental \\
PNH & Política Nacional de Humanização \\
MS & Ministério da Saúde \\
OMS & Organização Mundial de Saúde \\
RAPS & Rede de Atenção Psicossocial \\
SUS & Sistema Único de Saúde \\
TCLE & Termo de Consentimento Livre e Esclarecido \\
TMC & Transtornos Mentais Comuns \\
\hline
\end{tabular}




\section{SUMÁRIO}

APRESENTAÇÃO

ARTIGO 1 - CONSIDERAÇÕES HISTÓRICAS SOBRE A LOUCURA: INTERFACE ENTRE

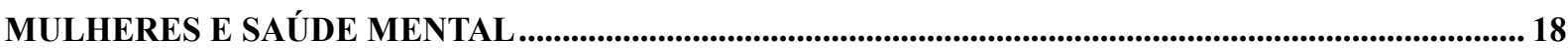

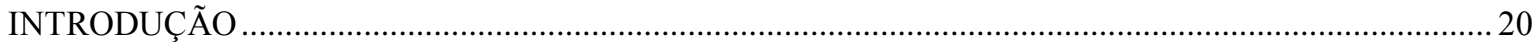

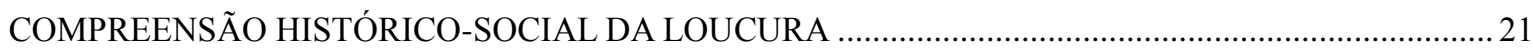

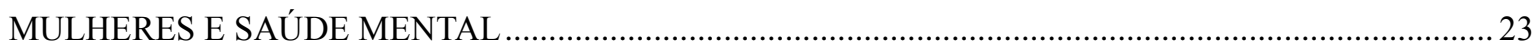

A CONDIÇÃO FEMININA E AS INSTITUIÇÕES PSIQUIÁTRICAS EM ALGUNS ESTUDOS

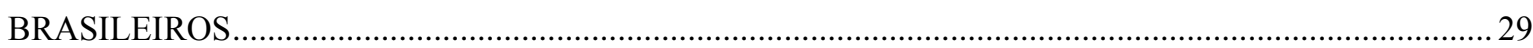

REFORMA PSIQUIÁTRICA BRASILEIRA, RELAÇÕES DE GÊNERO E MULHERES .............................. 34

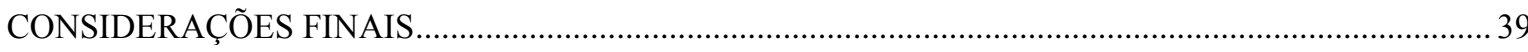

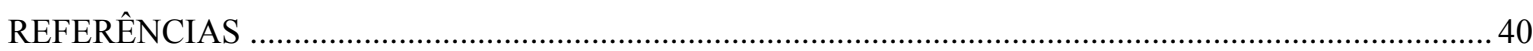

ARTIGO 2 - SAÚDE MENTAL E GÊNERO: O PERFIL SOCIODEMOGRÁFICO DE PACIENTES EM

UM CENTRO DE ATENÇÃO PSICOSSOCIAL ...................................................................................... 45

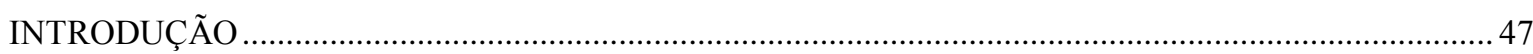

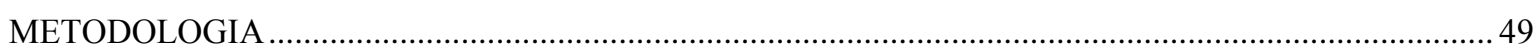

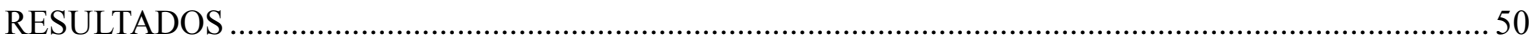

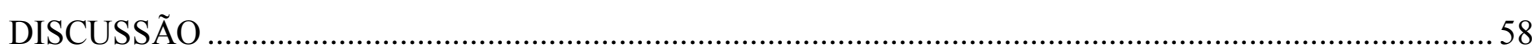

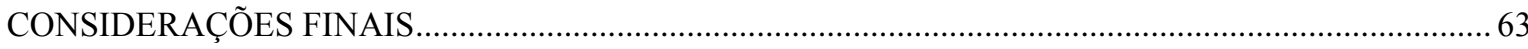

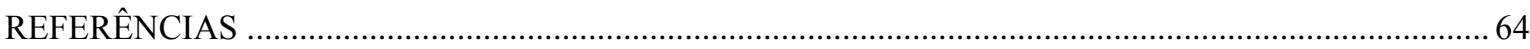

ARTIGO 3 - SAÚDE MENTAL E GÊNERO: O SOFRIMENTO PSÍQUICO E A VIOLÊNCIA CONTRA

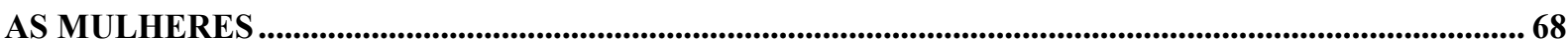

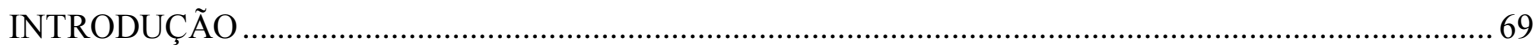

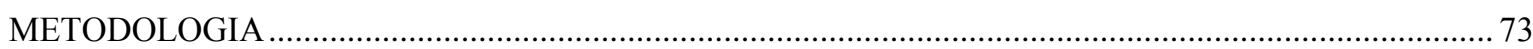

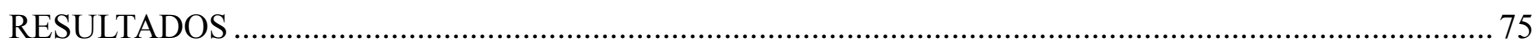

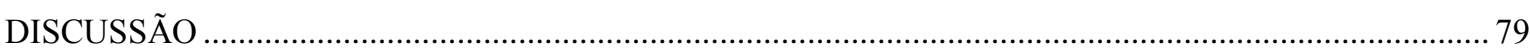

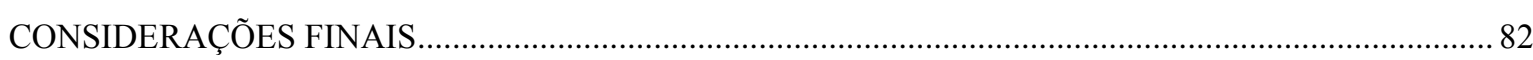

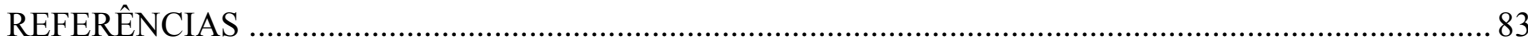


ARTIGO 4 - SOFRIMENTO PSÍQUICO E GÊNERO: NARRATIVAS DE MULHERES ATENDIDAS EM UM CENTRO DE ATENÇÃO PSICOSSOCIAL (CAPS II),................................................................ 87

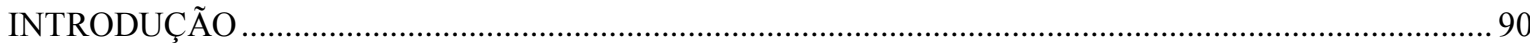

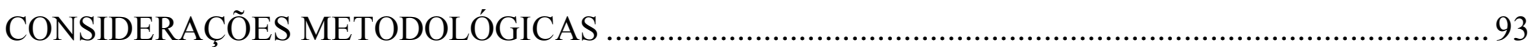

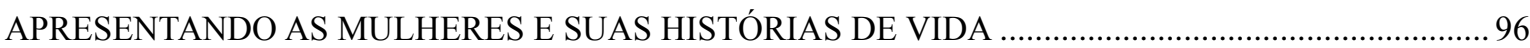

AS DIMENSÕES SUBJETIVAS DO SOFRIMENTO PSÍQUICO - HISTÓRIAS E EXPERIÊNCIAS DE

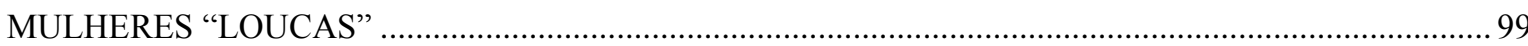

Trabalho como vulnerabilidade atravessada pelo gênero ........................................................................ 99

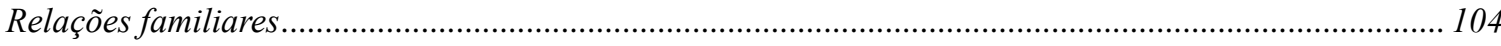

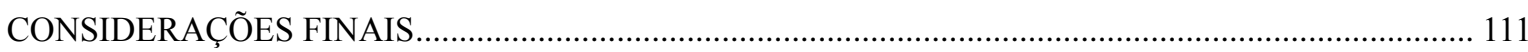

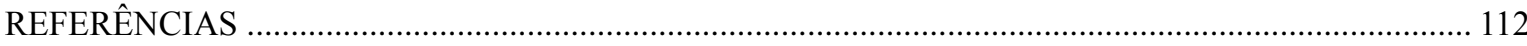

CONSIDERAÇÕES FINAIS..................................................................................................................................115

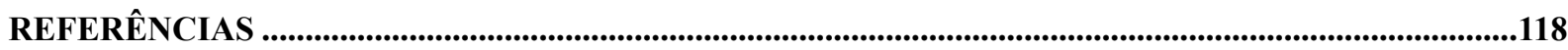

ANEXO A - PARECER DE APROVAÇÃO DO CEP IH/UNB .....................................................................119

ANEXO B - TERMO DE CONSENTIMENTO LIVRE E ESCLARECIDO (TCLE) ................................... 121

ANEXO C - ROTEIRO SEMIESTRUTURADO DE ENTREVISTA ....................................................... 122 


\section{APRESENTAÇÃO}

A saúde mental enquanto área de atuação despertou meu interesse desde a graduação em Terapia Ocupacional, no período de 1995 a 2000. Nessa época, disciplinas específicas e o estágio curricular em saúde mental contribuíram para o início de um processo pessoal e profissional que culminou em investimentos teóricos projetados em estudos sobre o lugar social da loucura. Autores como Franco Basaglia, Michel Foucault, Franco Rotelli, Erving Goffman foram a base da formação conceitual que tenho atualmente. Posso dizer que naquele momento, eu já sabia o que queria.

No entanto, do ponto de vista prático, não foi um processo romântico, em que tudo é maravilhoso. Inicialmente, o trabalho em um manicômio no interior paulista foi impactante, pois a instituição vivia entre o velho e o novo, em uma mistura entre o modelo tradicional e o processo de desinstitucionalização. Sobre as características dos internos podem-se elencar algumas, como baixo nível de autonomia e dependência para algumas atividades do cotidiano e um processo de envelhecimento (de homens e mulheres) envolvendo limitações culturais, físicas e psíquicas. Além disso, o período de internação de 20, 30, 40, 50 anos, com perdas dos vínculos familiares e sociais, era uma realidade institucional.

Mas as possibilidades advindas das lutas em prol da reforma psiquiátrica brasileira se constituíam no contexto dessa instituição, em forma de projetos desinstitucionalizadores, como a construção de lares abrigadores - pequenas casas localizadas nas terras do hospital, que funcionavam como repúblicas masculinas e femininas - e, também, como projeto mais ousado do Ministério da Saúde (MS), a implantação de Serviços Residenciais Terapêuticos (SRT), que consistem na passagem e/ou retirada dos pacientes internados em longa data, para viver no território, na sociedade. Esse cotidiano institucional funcionava em muitos momentos na contramão da história e, a passos lentos, caminhava em busca de avançar no contexto da Reforma Psiquiátrica.

O trabalho na Coordenação de Saúde Mental estadual da região sudeste do Estado de São Paulo estreitou e selou a minha atuação no cenário da gestão em saúde mental. A ênfase foi na consolidação da Política Nacional de Saúde Mental na perspectiva da organização da rede de saúde mental nos municípios de referência, com capacitação dos coordenadores municipais de saúde mental em temáticas diversas, disparadas pelos mesmos, como atenção a 
crise e internações, medicação, envolvimento profissional, formação de redes, território, responsabilização, acolhimento, diversidades de estratégias, processo de trabalho e avaliação das práticas de saúde mental. O envolvimento com esse trabalho fortaleceu o desejo de realização do mestrado na Universidade de São Paulo na Escola de Enfermagem de Ribeirão Preto e culminou no desenvolvimento da pesquisa de avaliação sobre uma política pública voltada especificamente para pessoas que passaram por um longo período de suas vidas internadas em hospitais psiquiátricos: o Programa "De Volta para Casa".

Tais experiências puderam ser enriquecidas, potencializadas, em especial nas reflexões presentes em minha dissertação de mestrado, e certamente serviram como fonte de motivação para o desenvolvimento do processo de doutoramento. Recentemente, o trabalho como docente na Universidade de Brasília/FCE, junto ao curso de Terapia Ocupacional, trouxe possibilidades de atuação como supervisora de estágio curricular em saúde mental no curso de terapia ocupacional, em um Centro de Atenção Psicossocial II (CAPS II), cenário desta pesquisa. Aliado ao trabalho como supervisora de estágio, concomitantemente, a entrada no Programa de Pós-Graduação em Psicologia Clínica e Cultura, na Universidade de Brasília, possibilitou olhar a saúde mental sob o viés de gênero, principalmente em disciplinas específicas do Programa: Gênero e Psicologia Clínica e Saúde Mental, Gênero e Psicopatologia.

Com o intuito de aprofundar a temática "gênero e saúde mental", este estudo teve como objetivo realizar uma leitura do sofrimento psíquico sob o enfoque das relações de gênero em um Centro de Atenção Psicossocial II de Brasília, a partir de dados sociodemográficos, dos sintomas e diagnósticos e a vivência das mulheres com o sofrimento psíquico. Para tanto, esta tese é composta de quatro artigos.

O primeiro artigo teve como objetivo discutir algumas concepções sobre loucura no Ocidente, ao longo dos processos de constituição e reestruturação do modelo de assistência psiquiátrica. Como a população deste estudo compõe-se basicamente de mulheres, buscou-se também resgatar a especificidade da relação entre mulheres e loucura, em uma perspectiva histórica, social e cultural. Por fim, abordaram-se as relações de gênero como questão importante na Saúde Mental brasileira na atualidade. Conclui-se que o modelo em saúde mental no Brasil apresenta um enfoque em intervenções centradas em sintoma-solução e inexiste uma agenda específica de gênero no cenário dos serviços públicos de saúde mental.

O segundo artigo foi baseado em uma análise documental, estudo quantitativo, transversal com produção de dados secundários em prontuários de 234 usuários/as, sendo 169 
mulheres e 65 homens de um CAPS II de Brasília, Distrito Federal. Objetivou caracterizar, comparar e analisar o perfil sociodemográfico entre mulheres e homens no período de 2012 e 2013, a partir da ficha de acolhimento e da evolução psiquiátrica. Os resultados evidenciaram características comuns entre os sexos, como baixos níveis de renda e escolarização, além de ocupações predominantemente baseadas nas diferenças de gênero, que reforçam a vulnerabilidade e desigualdades sociais, além de explicitar a precariedade da categoria trabalho na vida dos usuários/as. Pela diferença populacional entre o quantitativo de mulheres e homens, concluímos que esse CAPS II é um espaço da expressão subjetiva feminina. A implantação de projetos alternativos de trabalho e geração de renda e também investimentos em políticas públicas transversais, como forma de subsidiar a atual Política de Saúde Mental Brasileira, fazem-se necessários.

O terceiro artigo consiste de um estudo transversal também qualiquantitativo e com a mesma população: 234 usuários/as. Contudo, o objetivo foi realizar uma leitura sobre os diagnósticos e sintomas, a partir de uma perspectiva de gênero e saúde mental. Os resultados demonstram prevalência de diagnósticos relacionados aos transtornos do humor em mulheres e, nos homens, de esquizofrenia, transtornos esquizotípicos e delirantes. Esses dados, associados ao levantamento do perfil sociodemográfico e à análise dos dados dos prontuários, apontam para a medicalização e psiquiatrização da vida, sobretudo no caso das mulheres, cuja presença em episódios de violência chegou a 32,54\%.

Por fim, a partir de entrevista narrativa, o quarto artigo tem como enfoque a compreensão do sofrimento psíquico por cinco mulheres. Aborda o sofrimento psíquico de cinco usuárias de um Centro de Atenção Psicossocial (CAPS II), sob a perspectiva de gênero. Trata-se de pesquisa qualitativa, baseada em narrativas autobiográficas construídas por meio da técnica da entrevista narrativa. Após levantamento em 169 prontuários do serviço, as participantes foram selecionadas por configurarem casos clínicos considerados "exemplares" da temática em estudo. A análise e a interpretação do material produzido identificaram os núcleos narrativos significativos, reunidos em dois principais temas: 1. Trabalho como vulnerabilidade atravessada pelo gênero, que originou três subtemas: a) pobreza, infância e trabalho; b) uso e invisibilidade das performances de "mulher"; c) punição por não performar como uma "mulher"; e 2. Relações familiares interpeladas pelas violências sofridas (física, sexual e psicológica), em que aparecem três subtemas: a) relações conjugais; b) maternagem (exercício do cuidado tido como materno); c) ascendentes e ou relação com os pais. As narrativas analisadas mostram a vivência de situações dolorosas e estigmatizantes, histórias 
íntimas de expressão de muito sofrimento que versam sobre episódios de dor psíquica. Destacamos, na fala dessas mulheres, o modo como os eventos de suas vidas narrados como expressão de si são atravessados pelo gênero: na subjugação sexual, no tipo de papel exercido em conjugalidades predominantemente patriarcais, na (dificuldade do exercício da) maternidade, no trabalho doméstico sem reconhecimento.

Face a essas dores, um dos caminhos encontrados por essas mulheres foi a aproximação à religiosidade, aspecto muito importante em suas vidas, como alívio e busca de respostas para a dor psíquica. O cuidado recebido no CAPS II, embora o foco ainda fosse a doença, emerge como apoio importante a outras formas de ser e se relacionar no mundo. 


\section{ARTIGO 1 - CONSIDERAÇÕES HISTÓRICAS SOBRE A LOUCURA: INTERFACE ENTRE MULHERES E SAÚDE MENTAL}

RESUMO: As formas de compreensão da loucura não foram construídas de maneira linear ou unidimensionalmente no decorrer da história ocidental. Homens e mulheres considerados loucos ocuparam, em diversos momentos, distintos espaços sociais. Este artigo objetiva discutir algumas concepções sobre loucura, presentes em países europeus e no Brasil ao longo dos processos de constituição e reestruturação do modelo de assistência psiquiátrica. Busca também resgatar a especificidade da relação entre mulheres e loucura, em uma perspectiva histórica, social e cultural. Por fim, aborda a questão de gênero como categoria importante para compreensão de alguns processos presentes na Saúde Mental brasileira na atualidade. Conclui-se que a vulnerabilidade das mulheres se insere na questão sociocultural e histórica, que se expressa no cotidiano de forma hierárquica e diferencial. $\mathrm{O}$ atual modelo de cuidado em saúde mental ainda prioriza a busca por sintoma-solução, e inexiste uma agenda específica de gênero no cenário dos serviços públicos de saúde mental, o que ressalta a urgência da proposição de uma política de saúde mental que contemple essa lacuna.

Palavras-chave: saúde mental; loucura; gênero; condição feminina; desinstitucionalização.

\footnotetext{
ABSTRACT: The ways of understanding madness were not built in a linear or onedimensional way in the course of Western history. Men and women considered mad occupied, at different times, different social spaces. This work aims to discuss some conceptions of madness present in European countries and in Brazil through the creation of processes and restructuring of psychiatric care model. It also seeks to rescue the specificity of the relationship between women and madness, in a historical, social and cultural perspective. Finally, it addresses the issue of gender as an important category for understanding of some processes present in Brazilian Mental Health today. It concludes that women's vulnerability is part of the socio-cultural and historical question, which is expressed in daily life in a hierarchical and differential way. The current model of care in mental health still prioritizes the search for symptom-solution, and there isn't a specific gender agenda in the scenario of
} 
public mental health services, which highlights the urgency of the proposal of a mental health policy that fills that gap.

Keywords: mental health; madness; gender; women's status; deinstitutionalization.

RESUMEN: Las formas de entender la locura no fueron construidas de una manera lineal o unidimensional en el curso de la historia de Occidente. Los hombres y las mujeres consideradas locas ocuparon, en diferentes momentos, diferentes espacios sociales. Este artículo tiene como objetivo discutir algunas concepciones de locura presentes en países europeos y en Brasil a través de la creación de procesos y reestructuración del modelo de atención psiquiátrica. También trata de rescatar a la especificidad de la relación entre las mujeres y la locura, en una perspectiva histórica, social y cultural. Finalmente aborda la cuestión de género como una categoría importante para la comprensión de algunos procesos presentes en la Salud Mental de Brasil hoy. Llega a la conclusión de que la vulnerabilidad de las mujeres es parte de la cuestión socio-cultural e histórica, que se expresa en la vida cotidiana de forma jerárquica y diferenciada. El actual modelo de atención en salud mental todavía prioriza la búsqueda de síntomas-solución, y no hay una agenda específica de género en el escenario de los servicios públicos de salud mental, lo que pone de relieve la urgencia de la propuesta de una política de salud mental que llena ese vacío.

Palabras-clave: salud mental; locura; género; condición de la mujer; desinstitucionalización. 


\section{INTRODUÇÃO}

$\mathrm{Na}$ sociedade ocidental, historicamente, o conceito de loucura foi discutido sob diferentes concepções. Igualmente, ao longo dos anos, sua representação também não foi abordada de forma única, mas construída e interpretada de diversos modos e com base em diferentes pressupostos sociais e políticos. Por não ser contínua, a concepção de loucura sofreu interferências decorrentes de transformações históricas, nos diversos contextos sociais.

A discussão sobre a construção histórica do conceito de loucura foi objeto de estudo de Michel Foucault (1978). Neste estudo, pretende-se apreender, com base nessas questões, como a loucura foi concebida nesses momentos, quais mudanças ocorreram até se chegar à atual definição de loucura, alienação e doença mental. Busca-se entender, ainda, como se constituiu o saber/poder especializado da psiquiatria com base nas relações estabelecidas na sociedade ocidental, especialmente entre a loucura e as mulheres. Em síntese, procura-se compreender de que forma essas transformações possibilitaram e sustentaram a consolidação da prática de internamento e o discurso psiquiátrico a respeito das mulheres (FRICHE; FONSECA, 2003).

Para Foucault (1997), a figura do louco na sociedade ocidental foi a princípio construída nos seguintes períodos: Renascimento (final da Idade Média até o século XVI); Idade Clássica (século XVII e XVIII) e Modernidade (final do século XVIII e século XIX). Machado (2007) destaca a importância da obra História da Loucura na Idade Clássica, de Michel Foucault, não como uma história da psiquiatria, mas no sentido de que a intervenção da medicina em relação à loucura é datada historicamente e sobretudo de que "a psiquiatra é o resultado de um processo histórico mais amplo que pode ser balizado em períodos ou épocas que, de modo algum, diz respeito à descoberta de uma natureza específica, de uma essência da loucura, mas à sua progressiva dominação e integração à ordem da razão" (p. 52).

Não é proposta deste artigo percorrer todos os caminhos arqueológicos construídos por Michel Foucault sobre os saberes da loucura, mas explicitar alguns aspectos sobre suas condições no Ocidente que contribuem para a compreensão da situação, especificamente das mulheres loucas. 


\section{COMPREENSÃO HISTÓRICO-SOCIAL DA LOUCURA}

A loucura, na Idade Média, era concebida essencialmente como erro ou ilusão (FOUCAULT, 1997). Tratava-se da ruptura entre razão e desrazão (FRICHE; FONSECA, 2003) e início de um processo de dominação da loucura pela razão, isto é, "a destruição da loucura como saber que expressa a experiência trágica do homem no mundo em proveito de um saber racional e humanista centrado na questão da verdade e da moral" (MACHADO, 2007, p. 55). Deve-se ressaltar que, nessa época, seu tratamento priorizava o não asilamento; buscavam-se, na arte e no lazer, espaços de cura. Os hospitais gerais não tinham ainda finalidade exclusivamente médica e abrigavam pessoas consideradas indesejáveis sociais: pobres, malfeitores, indigentes, vagabundos e prostitutas (FOUCAULT, 1997).

Já na Idade Clássica, particularmente nos séculos XVII e XVIII, nota-se a intensificação da dominação da loucura pela razão (MACHADO, 2007). A criação acelerada de casas de internamento na Europa foi incentivada não como medida de diferenciação dos loucos, mas de saneamento, para "varredura" de todos aqueles considerados "desviantes sociais", ação essa justificada como indispensável para manter a ordem do espaço público (FOUCAULT, 1997). O tratamento da loucura, considerada um desvio social inaceitável e identificada com a desrazão, foi delegado à caridade leiga e religiosa em hospitais gerais, prática que persistiu até o final do século XVIII.

O período compreendido entre aproximadamente o final do século XVIII ao século XIX caracterizou-se pelas críticas à generalização do enclausuramento nos hospitais gerais e pela origem dos asilos e concepção da psiquiatria como especialidade médica. $\mathrm{O}$ médico Philippe Pinel "libertou" os loucos e loucas, com a consequente separação e diferenciação dos alienados. Segundo Foucault (1991), não se observava uma libertação dos loucos, e sim uma objetificação do conceito de liberdade. A teoria psiquiátrica, nesse momento, embasava-se na insanidade e no controle moral (GARCIA, 1995), ao passo que o tratamento baseado no emprego de meios higiênicos, físicos, dietéticos e farmacológicos deslocou-se para concepções morais de reeducação de hábitos dos alienados, o que, entretanto, não significou ausência da violência física nas terapêuticas utilizadas (PESSOTTI, 1999).

Dessa forma, com o início do Iluminismo, da chamada Era da Razão e do Pensamento Positivista, o saber psiquiátrico inscreveu-se no campo médico, e a loucura passou a ser objeto de observação crítica, concebida como doença mental, investigada cientificamente. A definição de um diagnóstico, para classificação de diferentes doenças, transformou o hospital 
em espaço de cura (FOUCAULT, 1979). A relação de objetividade era constitutiva do saber médico e critério da sua validade, sendo que o poder do médico era expresso por um sistema de diferenças e hierarquias (FOUCAULT, 2006).

Como local de abrigo para pobres, idosos e mulheres (CHESLER, 1989), o manicômio nasceu, de maneira contraditória, para defesa dos sãos contra a loucura. Um espaço para isolar, manter o louco "[...] trancado no espaço estreito da sua individualidade perdida e oprimido pelos limites impostos pela doença” (BASAGLIA, 2005, p. 25). Em Manicômios, prisões e conventos, Erving Goffman (2010) qualifica essas instituições pela capacidade institucional de transformar as vidas dos sujeitos, por meio da reclusão, em instituições totais. Nesses locais, o sujeito constrói uma "carreira moral” (GOFFMAN, 2010, p.109 ), isto é, o caráter total da instituição atua sobre o internado de forma que o seu eu passa por profundas transformações do ponto de vista pessoal e referentes ao seu papel social. As modificações ocorrem na imagem de si e dos outros, em um processo de mortificação, constituindo a primeira mutilação do eu, a barreira entre o mundo externo e a pessoa internada.

Assim, a imagem do sujeito institucionalizado corresponde ao ser humano petrificado nos asilos, sem perspectivas, objetivos ou projetos de vida, logo, um sujeito destruído pelo poder institucional e restrito em sua liberdade. Além das perdas pessoais e sociais impostas, a pessoa institucionalizada depara com um mundo repleto de regras e intervenções que agridem seu corpo e a transformam em um ser inofensivo e dócil (BASAGLIA, 2005).

Em suma, no decorrer da história da loucura no Ocidente, a expressão da violência sofrida por homens e mulheres foi influenciada, em dado momento histórico, por transformações sociais e políticas, sobretudo pela constituição do saber médico. As representações sociais sobre a loucura compreendiam desde um contexto sub-humano de animalidade a uma condição de liberdade e de terapêuticas impostas.

Ao analisar o contexto das loucas vitorianas na Inglaterra, Showalter (1985) menciona que, tradicionalmente, os historiadores da psiquiatria conferiram pouca atenção às questões de gênero; e a fonte principal da história psiquiátrica - livros psiquiátricos, jornais médicos, minutas parlamentares, documentos jurídicos e jornalísticos - manteve em segundo plano as vozes das mulheres. Inclusive os críticos mais radicais da psiquiatria priorizavam a análise das relações entre sociedade (classe social) e loucura em detrimento da questão de gênero como determinante da carreira psiquiátrica individual e das instituições psiquiátricas, a exemplo de Michel Foucault (1978), em História da Loucura na Idade Clássica. Foucault, célebre e conceituado filósofo, não considerou as diferenças sexuais, ou seja, não explorou a 
irracionalidade e as distinções sexuais que o asilo silenciou e a que confinou a feminilidade (NASCIMENTO; ZANELLO, 2014). É sobre o lugar das mulheres consideradas loucas na cultura ocidental e sua condição subalterna no interior das instituições psiquiátricas da Europa e Brasil que discorrerão os próximos parágrafos.

\section{MULHERES E SAÚDE MENTAL}

A temática sobre a história do corpo na sociedade ocidental, especialmente o corpo feminino, pautou-se tanto na filosofia cristã quanto no saber médico, segundo a concepção de um corpo ameaçador, de pecados e de prazeres malditos. De acordo com Del Priore (1999), os mistérios da fisiologia feminina, ligados aos ciclos da lua, geravam uma dicotomia entre a sedução e a repugnância à menstruação, aos odores, ao líquido amniótico e às expulsões do parto.

Nesse sentido, cabe mencionar que, na Antiguidade, o modelo de sexo único foi estruturado para valorizar o patriarcado, segundo o qual as mulheres eram consideradas homens não pela natureza de corpos distintos, mas de acordo com seu grau de perfeição e calor vital, ou seja, as mulheres eram homens invertidos (a vagina como pênis interno e o ventre como escroto feminino) e menos quentes. Logo, o corpo da mulher era menos potente. Assim como a ejaculação era capaz de restabelecer o equilíbrio gerado por sintomas apáticos nos homens, nas mulheres, o sangue menstrual era uma "forma de evacuação para manter a economia de livre mercado dos fluidos a um nível apropriado" (LAQUER, 2001, p. 50), isto é, as mulheres tinham excessos de fluidos corporais, o que podia levá-las à loucura.

A relação entre mulher e loucura pode ser evidenciada em Del Priore (1999), no resgate às obras de Galeno, o qual associava a melancolia aos vapores advindos do sangue menstrual, agente causador de assombrosas e espantosas alucinações. Outra relação entre mulher e loucura, também apontada pela autora, assinala a presença de um útero que se deslocava e produzia loucura nas mulheres. Esse deslocamento, com posterior fixação do útero sobre outros órgãos corporais, produzia ansiedade, tonturas, vômitos, dores de cabeça e pescoço, além de resfriamento nas pernas e perda da fala (NUNES, 2010).

Já na Idade Média, com a propagação do conceito de um corpo feminino associado à malignidade, à impureza, à aliança com o demônio, as mulheres foram rotuladas pela 
Inquisição como bruxas (PESSOTI, 1994; SZASZ, 1976; TOSI, 1998). A valoração de uma vida perfeita, sem pecados e livre da concepção demonista prevaleceu sobre o conhecimento e a vida afetiva (PESSOTI, 1999). Segundo Perrot (2013), "as mulheres, geralmente condizentes de seu papel, foram por vezes tentadas pela subversão de um poder religioso que as domina e as nega” (p. 88). A afinidade entre mulheres e bruxarias foi explícita dos séculos $\mathrm{XV}$ ao XVIII e coincide com momentos de transformações, como o Renascimento, o Humanismo e a Reforma Protestante, em que católicos e protestantes acusavam as mulheres de praticarem bruxarias. Eram tidas como feiticeiras, heréticas, delegadas do demônio e causarem agravos à ciência e à medicina moderna, pois propunham curar corpos com ervas e fórmulas esotéricas (PERROT, 2013).

Sobre o confinamento de mulheres nesse período, estudos estatísticos, realizados no século XVII, evidenciaram aumento de doenças mentais em mulheres e maior número de internações em relação aos homens (GARCIA, 1995). Os estudos de Chesler (1989) sobre mulheres americanas institucionalizadas alertam para o fato de que, já no século XVI, elas eram "silenciadas" nos hospícios (e castelos) por seus maridos. Além disso, muitas delas, pobres e prostitutas, podem ter sido vítimas de violência física e sexual; no entanto, seus adoecimentos não eram vistos como consequência da violência e perseguição.

Segundo Del Priore (2014), entre os séculos XII e XVIII, a igreja identificava o corpo feminino como um mal sobre a terra, e a ênfase na função normativa do corpo feminino e a valoração da maternidade constituíam formas de a mulher se redimir dos seus pecados. $\mathrm{O}$ útero como território para procriação indicava uma mulher normalizada, e a ausência de fecundação era associada à doença acometida de paixões ou de melancolia, seguida de medo e tristeza. Essa autora enfatiza que

o critério do útero regulador da saúde mental da mulher irradiava-se em toda a
Europa Moderna - e, portanto, na metrópole lusa - difundindo uma mentalidade na
qual a mulher era física e mentalmente inferior ao homem e escrava de sua
fisiologia. Essa natureza própria e ordenada pela genitália reverberava os problemas
da alma feminina, fazendo da mulher um monstro ou uma criança incontrolável.
Vítima da melancolia, seu corpo abria-se para males maiores como a histeria, o furor
da madre, a ninfomania [.... (DEL PRIORE, 1999).

Dessa forma, a regulação do corpo feminino pela medicina foi dominada pela misoginia em virtude da associação mulher-veneno, pois o corpo da mulher era capaz de gerar coisas monstruosas, "sublinhando na mentalidade do período uma imagem deformada da mulher ora como feiticeira, ora como possuidora de um útero mágico" (DEL PRIORE, 1999, p. 20), encerrando-a em uma rede de determinações físicas e morais. Para Del Priore, o fim 
das teorias aristotélicas, que só ocorreu no século XIX, proporcionou o repensar da feminilidade das mulheres a partir de seu próprio corpo.

O século XIX trouxe outras dimensões vinculadas ao corpo feminino. "A imagem da mulher como um ser ambíguo e contraditório, misterioso e imprevisível, entre a virtude e degradação, ganhou um sentido específico", de um ser moral e socialmente perigoso, divulgado entre poetas, romancistas, médicos, higienistas, psiquiatras e, posteriormente, psicanalistas (ENGEL, 2007, p. 332). Nesse século, o corpo de homens e mulheres foi concebido sob diferentes visões, não mais um sexo único, mas distinto e expresso pelas demandas sociais, econômicas, políticas, culturais e eróticas (LAQUER, 2001), isto é, os corpos femininos e masculinos eram distintos por natureza, sendo as mulheres naturalmente consideradas inferiores.

Redefiniu-se e associou-se a relação entre mulher e natureza em oposição à imagem do homem atrelada à cultura. Socialmente, esperava-se que as mulheres fossem apenas esposas e mães, e qualquer comportamento divergente era interpretado como desvio da condição feminina, o que poderia levar à loucura. Enquanto a mulher era diagnosticada como doente mental, por meio de comprovado desvio em sua natureza, sobretudo sexual, considerava-se que a doença mental do indivíduo do sexo masculino decorria de alterações nos papéis a ele atribuídos, como trabalhador, provedor, entre outros. Ser mulher era, portanto, sinônimo de anulação e dedicação ao outro, filhos, maridos, parentes; e aos homens era atribuído o papel de proteger suas esposas dos perigos do mundo e exageros de qualquer atividade intelectual. Essas regras do comportamento feminino eram ditadas pelos médicos, tanto nas instituições asilares quanto fora delas, reforçadas por normas culturais da sociedade, criando assim a imagem de que eram "anjos do lar" e "guardiãs da virtude" (GARCIA, 1995).

Sobre o confinamento das mulheres em asilos psiquiátricos em meados do século XIX na Inglaterra, Showalter (1985) explicitou que os dados estatísticos mostraram que, entre os 18.775 internos, 11.162 eram mulheres, sendo que até o começo do referido século, os homens eram os mais institucionalizados. Em 1890, a predominância de mulheres internadas confirmou-se em todas as classes sociais e existiam, em todos os tipos de instituições, mulheres nas condições de cuidadoras e pacientes. As razões para o aumento da insanidade nas mulheres explicavam-se, primeiramente, pela expectativa de vida, pois, naquela época, elas viviam mais que os homens, o que tornava menos provável que obtivessem alta hospitalar. Outra questão importante sobre esse aumento relacionava-se à pobreza, uma vez que pessoas pobres tinham maior probabilidade de serem internadas e, por último, nem todas 
as mulheres internadas eram insanas; elas apenas apresentavam outras doenças, como tuberculose, epilepsia, deficiências físicas e retardo mental.

A autora denuncia também as condições precárias em que viviam as mulheres pobres nessas instituições: mãos e pés presos por cordas e correntes, cadeiras de contenção, algemas, banhos de surpresa, quartos frios, vestuário escasso, poucas roupas de cama e negligência médica. Os instrumentos de contenção eram frequentemente usados com forma de silenciar mulheres barulhentas, melancólicas, violentas, entre outras. Esta situação se agravava com a má administração: não existia piedade para aflição, idade ou sexo. No entanto, após as reformas das teorias vitorianas sobre a loucura, surgiu o fenômeno da "domesticação do insano", cuja base residia em um sistema de tratamento que abolia a contenção e priorizava o controle moral (bons hábitos, rotina e autodisciplina) e ambientes terapêuticos sem o uso da força (SHOWALTER, 1995).

Dessa forma, para Showalter (1995), o surgimento da louca vitoriana talvez estivesse relacionado ao nascimento da psiquiatria e suas instituições que, embora reconhecessem a pobreza, a dependência e a doença como fatores determinantes da superlotação das mulheres no asilo, reproduziam o pensamento psiquiátrico de que as mulheres eram mais vulneráveis à loucura, devido ao sistema reprodutor.

Assim, além das condutas morais da mulher, suas especificidades fisiológicas eram também consideradas fatores que as predispunham a doenças mentais, ou seja, seu aparelho reprodutor era potencialmente causador de doenças mentais (ENGEL, 2007). Essas questões relacionadas à doença mental da mulher e a seu ciclo reprodutivo ganharam visibilidade no século XIX no Ocidente (RODHEN, 2001; SHOWALTER, 1995), à medida que uma nova sociabilidade das famílias redefinia a maneira de ser mulher, legitimada pelo parecer do médico, especialmente dos alienistas, os quais, de antemão, já expressavam medo diante do sangue menstrual, concebendo-o como sinal de possível diagnóstico de alienação mental (ENGEL, 2007). Os psiquiatras ingleses utilizavam como método de tratamento para controle do sangue menstrual, dietas, procedimento de flebotomia e indicavam laxantes para menstruações irregulares. Para as meninas, a primeira menstruação marcava o início das diferenças e de uma existência mais limitada. A vida era, portanto, normal até a chegada do período menstrual e, durante o fluxo, as restrições às viagens, às atividades físicas, aos estudos e à vida social eram inevitavelmente impostas. Enquanto para os médicos vitorianos, o conhecimento sobre a puberdade gerou maior poder sobre o corpo feminino, as meninas 
cresciam convictas de sua dependência social, limitação e inferioridade (SHOWALTER, 1995).

Outro aspecto importante na definição dos distúrbios mentais foi vinculado à maternidade, pois

se, de acordo com a perspectiva médica, a realização da maternidade seria capaz de prevenir e até mesmo de curar os distúrbios psíquicos relacionados direta ou indiretamente à sexualidade e à própria fisiologia femininas, contraditoriamente a gravidez, o parto e o pós-parto seriam vistos como momentos extremamente propícios ao aparecimento ou à manifestação de tais distúrbios (ENGEL, 2007, p. 336).

Sobre as contradições da maternidade, Showalter (1995) menciona que, na segunda metade do século XIX, as mulheres inglesas pobres e com insanidade puerperal representavam de 7 a 10\% dos internos em hospícios públicos. Consideradas como mulheres indiferentes às convicções usuais de educação e desviantes na forma de se vestir e falar, transgrediam a cultura vitoriana de amor maternal, e, geralmente, sintomas de negligência e aversão ao marido e a crianças ocorriam com violência. Ou seja, o desvio abrangia um amplo espectro, desde excentricidade a infanticídio, considerado o pior crime em uma sociedade que exaltava a maternidade.

Portanto, enquanto a maternidade era vista como sagrada, manias puerperais violentas expressavam a sexualidade das mulheres e chocavam os médicos, os quais tinham dificuldades em explicar o infanticídio de forma a preservar o mito da maternidade e o instinto materno. A justificativa era a de que, após o nascimento da criança, a mente da mulher tornava-se demasiadamente fraca, e o controle sobre o seu comportamento diminuía. Já os juízes tinham dificuldade para sentenciar essas mulheres, pois consideravam os problemas sociais daquelas que não eram casadas ou que se encontravam em situações desfavoráveis, bem como os traumas psicológicos decorrentes do papel maternal. Diferentemente, os médicos não atribuíam importância ao impacto social da violência puerperal e, portanto, não ouviam os sentimentos das mulheres e ignoravam suas demandas no decorrer do processo de cura (SHOWALTER, 1995).

Naturalmente que a cultura ocidental, ao longo da história, abonou a submissão e a opressão da mulher pelo homem com base em uma suposta fraqueza fisiológica (GARCIA, 1995), permitindo assim que a natureza feminina fosse a justificativa dos desajustes psíquicos da mulher. Sobre a relação mulher-natureza, Basaglia (1987) destaca que 
tudo o que se refere à mulher está dentro da natureza e de suas leis. A mulher tem a menstruação, fica grávida, pare, amamenta, tem a menopausa. Todas as fases de sua história passam por modificações e alterações de um corpo que se ancora solidamente na natureza. Esta é a causa para que a nossa cultura tenha deduzido que tudo aquilo que é a mulher o é por natureza: é frágil por natureza, obstinada e doce por natureza, maternal por natureza, estúpida por natureza, sedutora por natureza, e também pérfida e amoral por natureza. O que significa que as mulheres fortes, feias, privadas de atrativos, inteligentes, não maternais, agressivas, rigorosamente morais no sentido social são fenômenos "contra natura" (p. 35).

Aquelas que contrariavam sua pressuposta natureza, que não aceitavam as condições impostas, eram consideradas rebeldes e mentalmente perturbadas e, entre todas as doenças, a histeria era uma de suas principais manifestações (GARCIA, 1995). Assim, ao final do século XIX, a histeria, para a medicina, estava relacionada à essência feminina, o que reforçou e legitimou o controle das mulheres por meio do confinamento, sendo que "os modelos psiquiátricos masculinos tornaram-se modelos culturais, e tanto a teoria psiquiátrica quanto a vigilância da moral pública transformaram a diferença entre os gêneros e a loucura em uma enfermidade feminina" (GARCIA, 1995, p. 50).

Destaca-se que, desde a tradição grega, a histeria era uma questão inerente à mulher, vinculada à insatisfação sexual ou ao desejo de procriar, ideias estas também defendidas pelos médicos medievais (ENGEL, 2007; NUNES, 2010). O estudo das epidemias histéricas na medicina moderna reconheceu Jean-Martin Charcot (1825-1893) como célebre pesquisador da histeria no hospital parisiense La Salpêtrière. Segundo esse pesquisador, a moléstia assemelhava-se a uma doença física que causava defeito hereditário ou lesão traumática no sistema nervoso central, podendo ser deflagrada por trauma físico ou emocional em homens e mulheres vulneráveis, sendo a hipnose seu principal método de tratamento. Embora insistissem que a histeria não era uma disfunção sexual e nem inerente às mulheres, Charcot e sua equipe, contraditoriamente, relacionavam o problema à personalidade feminina (SHOWALTER, 1995).

Embora algumas correntes da medicina considerassem que a histeria se localizava no cérebro e não no útero, isto não abalou a concepção uterina da moléstia, pois se partia do pressuposto de que o cérebro era dominado pelo útero e por seus instintos. Desse modo, para os médicos alienistas, a histeria apresentava vínculo estreito com as anomalias da sexualidade, ou seja, a ausência de relações sexuais ou aquelas mantidas sem a finalidade procriadora, além dos lascivos excessos sexuais das mulheres, caracterizados como desvios sexuais, eram considerados etiológicos à doença histérica (ENGEL, 2007). 
Dessa forma, a sexualidade feminina constituía uma inquietação médica. A busca pela cura para a histeria explicitava os mecanismos de controle, especialmente nos asilos psiquiátricos. Ao longo do século XX, novas terminologias diagnósticas foram surgindo, como psicose maníaco-depressiva, frigidez, ansiedade, sem, no entanto, significar mudanças acentuadas no que se refere à humanização do tratamento. Ao contrário, a punição das mulheres, ora pelo "mau comportamento", ora pela recusa em obedecer às regras estabelecidas, era norma na sociedade, o que legitimou o poder familiar de internar, sendo os pais e maridos os principais responsáveis por essa decisão.

Enquanto o nome simbólico atribuído ao transtorno feminino mudou durante distintos períodos históricos, a assimetria de gênero da representação tradicional permaneceu (SHOWALTER, 1995). Embora as lutas e transformações pela assistência psiquiátrica na Europa, EUA e Brasil, a partir da metade do século XX, tenham possibilitado reformulações conceituais importantes, do ponto de vista social, político e cultural, foram (e ainda são) insuficientes, pois o confinamento, enquanto representação de invalidação (BASAGLIA, 1983) e reafirmação da cultura patriarcal, mantém a violência no interior dos asilos, onde, particularmente as mulheres na condição de sujeitos, com suas necessidades e desejos, inexistem e continuam silenciadas em seu sofrimento.

\section{A CONDIÇÃO FEMININA E AS INSTITUIÇÕES PSIQUIÁTRICAS EM ALGUNS ESTUDOS BRASILEIROS}

No Brasil, a loucura, como problema social, e sua presença em nosso cenário ocorreram na sociedade rural pré-capitalista, em um contexto de desordem e ameaça à paz social frente aos processos de urbanização e industrialização. No entanto, a doença mental permaneceu "silenciosa por muito tempo, suas manifestações diluídas na vastidão do território brasileiro" (RESENDE, 2007, p. 31). Os loucos (e loucas) eram abandonados, ora em prisões e casas de correção, ora em abrigos de mendigos ou nas Santas Casas de Misericórdia; contudo, não era comum encontrá-los em enfermarias e hospitais para tratamento médico (RESENDE, 2007; AMARANTE, 1994).

Somente ao final do século XIX começaram a se delinear no Brasil novas perspectivas sociais, políticas e econômicas sob o regime republicano, o que trouxe uma série de imposições, de acordo com os interesses dominantes. Segundo Cunha (1989), o ideal das 
classes dominantes era aliar modernidade e civilização no combate ao acelerado crescimento urbano e à indispensável incorporação de pessoas desprovidas de cidadania e acesso ao mercado de trabalho. Do mesmo modo, houve formulação e implementação de novas estratégias de disciplinarização e de repressão dos corpos e mentes. Portanto, no Brasil republicano, em um período de reestruturação das relações de trabalho e complexificação do espaço urbano, emergiram novos conceitos sobre ética no trabalho e padrões de moralidade para os comportamentos afetivos, sexuais e sociais (ENGEL, 2007).

Em resposta à urgência de reorganização do espaço público, a psiquiatria brasileira abriu espaços para instalação de instituições disciplinares em um processo de asilamento e medicalização do social (AMARANTE, 1994). Profundamente marcada por influências europeias, a psiquiatria reproduziu o modelo asilar de conceber os loucos, as loucas e a loucura, à medida que fundou, em 1852, a primeira instituição psiquiátrica, localizada no Rio de Janeiro - o Hospício Pedro II - legitimando, assim, o pensamento alienista no Brasil.

O discurso médico sobre a alienação mental, baseado no pensamento de Pinel e Esquirol, foi rapidamente incorporado, deslocando-se de uma perspectiva assistencialista para defesa da intervenção do Estado e da ciência. Acresce-se a pressão social para o enclausuramento, ou seja, para que os loucos fossem retirados das ruas, por meio de força policial, nas capitais e no interior das províncias, o que legitimou a exclusão social por meio da prática eugênica (ODA; DALGALARRONDO, 2005).

Nos séculos XIX e XX, diversas instituições psiquiátricas foram construídas em vários estados brasileiros (ODA; DALGALARRONDO, 2005; AMARANTE, 1994; ENGEL, 2007; MACHADO et al., 1978). Atualmente, dados do Ministério da Saúde (BRASIL, 2012) demonstram que o número de leitos em hospitais psiquiátricos por Estado é variável: sete possuem percentual acima da média nacional, com destaque para o Rio de Janeiro, Alagoas, São Paulo e Paraná. Pará, Acre e Amazonas possuem um único hospital em seus territórios, embora demandem incentivos à organização das redes psicossociais.

Em alguns Estados brasileiros, como Rio de Janeiro, São Paulo e Bahia, têm sido realizados estudos populacionais, como censos psicossociais, com o objetivo de caracterizar o perfil populacional, por sexo, de moradores das instituições psiquiátricas, com vistas à implementação de estratégias para desinstitucionalização (GOMES et al., 2002; BARROS; BICHAFF, 2008; BARROS et al., 2014; PITTA, 2004). Dados desses diferentes Estados evidenciam proporção populacional variável entre homens e mulheres e um número significativo de manicômios, concentrados especialmente em São Paulo e no Rio de Janeiro. 
No que se refere particularmente às mulheres, autores como Cunha (1989), Wadi (2006), e Facchinetti, Ribeiro e Muñoz (2008) discutem trajetórias e condições sociais, assim como espaços ocupados por mulheres consideradas loucas no início do século XX no Brasil. Esses estudos são citados na presente investigação por terem sido realizados em grandes instituições psiquiátricas brasileiras, construídas entre os séculos XIX e XX, e pela interface com questões atuais vivenciadas nos contextos das intervenções na Saúde Mental brasileira.

Como mencionado, a naturalização do papel social atribuído às mulheres levou a uma definição da condição feminina baseada em determinações biológicas de seu sexo, o que atraiu a atenção da medicina e do alienismo no final do século XIX e possibilitou uma concepção do corpo feminino relacionada à ideia de que seu espírito era agitado e turbulento (CUNHA, 1989). Compreendia-se que a saúde mental da mulher era definida pela relação entre corpo e sexualidade. Tratava-se de um dispositivo de controle social, de patologização e naturalização de um perfil de mulher problemática, sendo o médico a figura central que definia o diagnóstico. Assim, os discursos psicopatológicos mascaravam ideologias sociais gendradas, fazendo-se acreditar serem expressão de verdade científica.

Em estudo sobre mulheres internadas no Hospital Juquery, Cunha (1989) delineou, a partir dos prontuários psiquiátricos (1895 a 1930), a característica populacional da instituição: “[...] mulheres pobres de imigrantes que mal conseguiam ainda falar a língua do país e de negras recém-egressas da escravidão, geralmente classificadas nas rubricas mais fortes da nosografia: idiotas, imbecis, degeneradas inferiores" (p. 16) e destinadas ao silêncio dos dormitórios coletivos, o que explicitou estereótipos e preconceitos de gênero, classe e raça. Para a autora, "a crença em uma inferioridade 'natural' marca todas as histórias de mulheres em situação de internamento" (p. 14). O modelo a ser seguido pelos alienistas era o das mulheres "de família", consideradas exemplos a serem seguidos, cujas condutas eram impecáveis na esfera familiar. Os prontuários analisados por Cunha (1989) evidenciaram mulheres cujo processo de internação estava vinculado à independência financeira e profisssional e à recusa ou não ao matrimônio. A autora menciona que se "há um espaço social menor a ser ocupado, há também menores oportunidades de transgressão - o que permite identificar as transgressoras como casos eminentemente patológicos" (p. 129), sendo que, 
do ponto de vista dos padrões construídos pelo saber psiquiátrico, em suas tentativas de generalização e teorização sobre o "normal" e o "patológico", a quebra do modelo normatizado de comportamento feminino significará sempre alguma forma de recusa ou resistência ao papel "natural" de mãe-e-esposa. Estratégia de reforço da família, a psiquiatria conta com sua cumplicidade: "erigidas em instância jurídica, gozando das prerrogativas de um tribunal" a quem cabe julgar as condutas, efetuando a divisão entre razão e loucura e transformando-se num dos critérios essenciais da razão triunfante, são elas que pedem e obtêm, com uma facilidade que hoje pode parecer espantosa, o internamento de mulheres desviantes. Estas últimas, aliás, constituem, na escala do internamento, os maiores contingentes - dado que pode ser parcialmente explicado pela maior facilidade das famílias em livrar-se de seus fracassos afetivos do que em abrir mão do responsável pela manutenção financeira. Há pouca hesitação para a internação de mulheres, decidida por seus maridos, pais, irmãos à menor "suspeita" ou desconforto causado por seu comportamento; os homens ao contrário, em geral, precisavam tornar-se muito incômodos, "reincidir", adquirir uma visibilidade incontestável em sua loucura antes que as famílias decidissem enviá-los ao hospício (Cunha, 1989, p. 129)

O gênero era apenas uma forma orgânica e psicológica para diferenciar homens e mulheres e, assim, os alienistas homogeneizavam todas as mulheres enquanto categoria biológica (CUNHA, 1989). Dessa maneira, o discurso e a prática misógina da medicina reforçavam certos papéis e estereótipos sociais que garantiram a dominação, tanto de gênero como de classe, o que resultou na atribuição de distintos papéis a diferentes mulheres e simbólica morte silenciosa (CUNHA, 1989). As mulheres consideradas loucas foram encarceradas e submetidas a uma condição subalterna de domesticação de seus corpos, desqualificadas, anuladas, mortificadas e etiquetadas em seu lugar social. Qualquer tentativa de exercer o empoderamento era interpretada como não possibilidade de cura e passível de punição, considerando que o ideal de gênero envolve o assujeitamento e a docilidade.

Nesse sentido, estudo sobre as experiências de vida de mulheres internadas no Hospício São Pedro (HSP), entre os anos de 1884 a 1923, objetivou observar e discutir os motivos das saídas das mulheres do HSP, com base em prontuários e artigos médicos da época, em uma perspectiva de historicização de suas experiências em instituição manicomial. Wadi (2006) reuniu fragmentos das trajetórias dessas mulheres, histórias por vezes silenciadas, de características diversas - gênero, raça/etnia, classe e idade. A autora assinala que, apesar do ingresso de mulheres ter sido menor em relação ao de homens no HSP, elas constituíram o maior contingente de internos porque também saíram menos. No entanto, “quando se trata de mulheres 'pretas' e 'pardas', estes eram nitidamente superiores aos encontrados para homens e mulheres 'brancos' e homens 'pretos' ou 'pardos'. [...] Verificouse que $44 \%$ das mulheres de cor 'parda' e $46 \%$ das mulheres de cor 'preta' que saíram do HSP o fizeram em razão de falecimento" (p. 76). 
Segundo Wadi (2006, p. 72), há ainda uma interseccionalidade gênero-raça nessa exclusão social, em que os olhares da "psiquiatria nascente ou da filantropia preocupada em desafogar o hospital de caridade de seus indesejáveis foram suficientes" para internação no hospício. Os diagnósticos diversos rotulavam as mulheres pesquisadas como alienadas: "lipemania" ou "loucura triste" (melancolia). Segundo afirmou Calmeil, discípulo de Esquirol, em 1876, “esse tipo de loucura atingiria mais as mulheres; entretanto, nos homens, com maior frequência, a melancolia seria incurável”.

Entre as causas físicas do desenvolvimento da doença, as que atingiam com mais frequência as mulheres eram: "a chegada da primeira menstruação, as irregularidades menstruais, a gravidez, o período pós-parto, o momento da menopausa, o abuso dos prazeres venéreos e o onanismo" (WADI, p. 72); outros diagnósticos foram definidos na época, como "hypermaníaca", “debilidade mental" e "excitação maníaca", além das moléstias mentais características da velhice, a psicose de involução, a arteriosclerose cerebral e a demência senil. A autora pontua que se estabeleceu para as mulheres, com base nos pressupostos médicos, uma identidade visível em sua internação como loucas:

\begin{abstract}
abandono, velhice, desânimo, tristeza, pobreza, sendo que a conjugação de atributos de geração/classe/gênero construiu esta identidade, além de comportamentos associados à quebra dos papéis normativos socialmente atribuídos - delimitam as possibilidades e o destino das mulheres internas, as quais se perderam no labirinto institucional e só se encontraram ou foram encontradas por meio de gestos extremos (suicídio) ou na lenta agonia, ano após ano, que as levou do cemitério dos vivos ao dos mortos (WADI, 2006, p. 78),
\end{abstract}

ou seja, a morte como única possibilidade.

Outro estudo sobre mulheres institucionalizadas no Hospício Nacional de Alienados (HNA), no Rio de Janeiro, no período de 1900 a 1913, buscou estabelecer uma cartografia das práticas psiquiátricas. Os autores Facchinetti, Ribeiro e Muñoz (2008) problematizaram a concepção de loucura feminina no início do século XX e propuseram uma análise diagnóstica que revelou prevalência de histeria até a década de 1920 e de psicose maníaco-depressiva até 1930. Dessa forma, com base na comparação de dois casos femininos de histeria, em que houve alteração substantiva na compreensão etiológica da doença, os autores concluem que 
para a vida dessas mulheres, entretanto, suas condutas desviantes foram, em ambos os casos, tratadas igualmente como patológicas e justificaram sua internação em uma instituição asilar, para que pudessem ali ser tratadas e curadas. Assim, Paola e Maria foram internadas na seção Esquirol, tendo como terapêutica, além do medicamento "estrato de fluido de maracujá", o isolamento do asilo, previsto como capaz de acalmar seus ânimos exaltados e trazê-las de volta à consciência de seus papéis sociais. Maria e Paula são exemplos clínicos que se repetem às centenas nos Livros de Observações Clínicas. Nesses casos ressalta-se a importância, dada pelos médicos, ao não cumprimento das obrigações domésticas e maternais como sinais e sintomas da insanidade. Portanto, percebemos que a constatação do desvio patológico tornava-se visível no nível dos comportamentos, sendo enfatizado e legitimado pelo não cumprimento dos "deveres" de mãe e esposa, em um momento em que os excessos, os desvios e as transgressões eram tratados como sintomas psicopatológicos (FACCHINETTI; RIBEIRO; MUÑOZ; 2008, p. 710 grifo nosso).

Esses estudos explicitam e denunciam as condições vividas pelas mulheres nos asilos brasileiros, a saber: mulheres rotuladas com o papel de loucas, restritas no espaço social e inscritas no termo "natureza da mulher". A despeito de diversas transformações, muitos desses valores explicitados acima persistem, fazem parte da nossa vida cotidiana e continuam mediando nossa cultura.

Sabemos que, atualmente, o número de mulheres excluídas, abandonadas nas instituições psiquiátricas, é significativo, sem contar as que sofrem cotidianamente no contexto dos serviços comunitários de saúde mental. Embora atualmente a conjuntura seja outra, face às lutas antimanicomiais e transformações sociais, políticas e técnicas, algumas funções do dispositivo institucional, como exclusão, separação, coerção, relações de poder e estigma no cenário da Reforma Psiquiátrica Brasileira, ainda representam desafios.

\section{REFORMA PSIQUIÁTRICA BRASILEIRA, RELAÇÕES DE GÊNERO E MULHERES}

Somente a partir do século XX, o modelo asilar, de fato, passou a ser objeto de discussão e entrou em declínio, impulsionado pelos movimentos da antipsiquiatria, comunidade terapêutica, psicoterapia institucional e a política de setor, psiquiatria comunitária, antipsiquiatria e a psiquiatria democrática ${ }^{1}$. Assim, o papel hegemônico das instituições psiquiátricas foi questionado de diversas maneiras, em vários momentos. Abriase, então, a possibilidade de ativar diferentes dispositivos de tratamento e assistência (SARACENO, 1999). Todavia, não se tratava ainda de extinguir os manicômios enquanto

\footnotetext{
${ }^{1}$ Obras que aprofundam a temática: DESVIAT, Manuel. (1999). A reforma psiquiátrica. Rio de Janeiro: Fiocruz; AMARANTE, Paulo (1995). Loucos pela vida: a trajetória da reforma psiquiátrica no Brasil. Rio de Janeiro: Fiocruz.
} 
instituições de violências (BASAGLIA, 2005), mas de sugerir alternativas em substituição às formas vigentes de intervenção psiquiátrica e suas finalidades sociais.

O processo de redemocratização e as pressões dos movimentos sociais, associados à luta pelos direitos humanos, levaram à implantação e implementação de projetos de mudança na área da assistência à saúde mental em vários Estados brasileiros, configurando o movimento pela Reforma Psiquiátrica. Trata-se de um momento de crítica às instituições asilares, marcado pela premente necessidade de modificar essas estruturas institucionais. Nesse contexto, nas últimas décadas, vem sendo delineada no Brasil uma transformação da assistência em saúde mental, por meio da implantação dos novos dispositivos de atenção psicossocial. É um passo na tentativa de ruptura com o paradigma psiquiátrico hegemônico, que consiste no deslocamento de uma perspectiva biológica, de uma relação individual, para a compreensão da pessoa em seu contexto de existência, de relações familiares e sociais (PITTA, 2010; AMARANTE, 1995; AMARANTE, 1994).

No que se refere às Políticas de Saúde Mental, a Reforma Psiquiátrica Brasileira suscita importantes questionamentos e assim intervém no campo das relações da sociedade com a loucura, transformando-as. Isso vem ocorrendo por meio de formulações das políticas e estratégias de inclusão social dos sujeitos, processo ético de inclusão, solidariedade e cidadania. Essas ações integram um processo social complexo (ROTELLI et al., 1990) que englobou (e ainda engloba) a mudança do paradigma do cuidado em saúde mental.

Amarante (1995) define a Reforma Psiquiátrica Brasileira como um movimento social que teve início em meados da década de 1970; porém, Pitta (2010, p. 3) argumenta que "não é consenso o lugar, o tempo e os atores que desencadeiam a Reforma Psiquiátrica Brasileira". Segundo consta nos documentos ministeriais, somente a partir da década de 1990, a formulação de políticas públicas de saúde mental impulsionou a fundação de serviços públicos de saúde mental, por meio das Portarias 189/1991 e 224/92, o que, para Pitta (2010), significou a reforma como política pública consentida.

Caminhou-se, a partir do ano 2000, para a Reforma Legal, com a criação de um importante arcabouço normativo, de expansão da rede comunitária e do controle dos hospitais (PITTA, 2010), a exemplo dos vários Centros de Atenção Psicossociais distribuídos pelo Brasil. Dessa forma, projetos de redução dos leitos psiquiátricos e a organização de serviços na comunidade favoreceram novos passos rumo à garantia dos direitos humanos, valorização da vida e da dimensão subjetiva. Em 2012, o Ministério da Saúde divulgou a Rede de Atenção Psicossocial (RAPS), estabelecendo assim a atenção em saúde mental em vários 
pontos estratégicos, colaborando para a valorização de estratégias de reabilitação psicossocial, eixo transversal da política pública de saúde mental.

Apesar dos desafios inerentes ao cotidiano dos serviços de saúde mental, que não serão debatidos profundamente neste texto, não podemos deixar de reconhecer que a Reforma Psiquiátrica brasileira alterou, de forma inegável, as práticas cotidianas, expandiu os serviços e impactou a saúde mental da população. Há evidências de maior efetividade, seja em nível individual ou social, na assistência a pessoas com transtornos mentais que estão sendo tratadas na comunidade, quando comparadas àquelas mantidas em regime de privação de liberdade (PITTA, 2010). Sobretudo após a aprovação da Lei 10.216/01, que dispõe sobre a proteção e os direitos das pessoas portadoras de transtornos mentais e redireciona o modelo assistencial em saúde mental (BRASIL, 2001), as práticas no campo da atenção psicossocial trouxeram contribuições valiosas em termos de consolidação da rede substitutiva, não hospitalocêntrica e manicomial (DIMENSTEIN, 2011).

Esse processo, ainda em construção, abriu possibilidades de reflexão, no cenário nacional, sobre a compreensão da loucura no contexto nas relações sociais, sua dimensão política e a produção de serviços territoriais e comunitários. No entanto, as relações de gênero, tão presentes nos espaços psicossociais dos serviços de saúde mental, parecem inexistir nesta reflexão (MALUF, 2010; ANDRADE, 2010; ZANELLO, 2010). O Ministério da Saúde, embora avalie as relações de gênero como determinantes da saúde mental das mulheres, somadas às condições socioeconômicas e culturais, não instituiu uma estratégia nacional de abordagem do problema (BRASIL, 2007).

Apesar da grande produção brasileira no campo da antropologia sobre doença e perturbação, saúde mental, cultura psicanalítica e doença nervosa, as abordagens de gênero no campo da saúde mental ainda são insuficientes. No entanto, esses estudos assumem especial importância em virtude do possível deslocamento, nos últimos anos, entre populações urbanas, de associações entre doenças nervosas, psicologização e medicalização dos processos subjetivos (MALUF, 2010). O movimento da reforma psiquiátrica ainda depara com o enfoque predominante em questões que envolvem diagnóstico, categorização, ordenação e classificação das experiências da vida em detrimento das particularidades, especificidades, singularidades, pluralidades e diferenças de experiências entre os sujeitos (ANDRADE, 2010).

Particularmente nos serviços de saúde mental, a condição feminina tem mostrado que as mulheres constroem uma "carreira psiquiátrica" (CHESLER, 1989), pois não há 
intervenções direcionadas para as especificidades de gênero. E a forma como o sofrimento é abordado evidencia um contexto gendrado, visto que o deslocamento do "paradigma psi" para a patologização da experiência e medicalização do cotidiano disseminou não apenas a linguagem médica, mas os seus modelos de adoecimento e cura (MALUF, 2010).

Embora essa realidade se configure no campo da Saúde Mental, em outras áreas, tais como sociologia, antropologia, história, literatura, filosofia e psicologia, houve a generalização do conceito de gênero a partir dos anos 1980 e 1990. Essa generalização trouxe a propagação de um pensamento de desnaturalização biológica das categorias de homem e mulher e da construção da dimensão social e cultural das noções de feminino e masculino (CORRÊA, 2002).

Como assinala Butler (2014), o gênero não é uma identidade estável ou um local de ação, ou um conjunto de vários atos, mas uma identidade construída. Para ela,

\begin{abstract}
supor que gênero sempre e exclusivamente significa as matrizes "masculino" e "feminina" é perder de vista o ponto crítico de que essa produção coerente e binária é contingente, que ela teve um custo, e que as permutações de gênero que não se encaixam nesse binarismo são tanto parte do gênero quanto seu exemplo mais normativo. Assimilar a definição de gênero à sua expressão normativa é reconsolidar inadvertidamente o poder da norma em delimitar a definição de gênero. Gênero é o mecanismo pelo qual as noções de masculino e feminino são produzidas e naturalizadas, mas gênero pode muito bem ser o aparato através do qual esses termos podem ser desconstruídos e desnaturalizados (p. 253).
\end{abstract}

Portanto, sua importância enquanto categoria de análise social, além de considerar o caráter cultural das construções identitárias das pessoas, permite compreender nossos próprios estereótipos, posicionamentos e posturas no que tange a ser homem ou mulher (CASARES, 2008). Há vários conceitos associados a essa categoria: relações, estratificação e estereótipos de gênero, entre outros; isto é, não há uma definição unívoca de gênero, sendo seu significado sujeito a constantes mudanças. $\mathrm{O}$ gênero evidencia que as diferenças sociais entre homens e mulheres não são imutáveis, universais e objetivas.

Neste sentido, inserir fatores socioculturais na experiência do sofrimento abre um novo campo de reflexões, isto é, a cultura, em seu caráter constitutivo, a qual cria/proporciona caminhos de subjetivação, nos quais as relações de gênero são um fator importante (ZANELLO; BUKOWITZ, 2012). Corroborando essa discussão, alguns estudos brasileiros debatem a "invisibilidade" de gênero no contexto da reforma psiquiátrica e Saúde Mental. São investigações segundo dimensões analíticas no campo da psicologia social que versam sobre o processo da reforma psiquiátrica e as questões de gênero, no âmbito da assistência, militância e política pública (ANDRADE, 2010), medicalização, diagnósticos, sintomas e relações de 
gênero (ZANELLO et al., 2011; ZANELLO; BUKOWITZ, 2012; ZANELLO; SILVA, 2012).

A articulação entre saúde mental e gênero requer uma discussão que considere os fatores sociais que engendram os transtornos mentais, com vistas a abordar, de forma diferenciada, o sofrimento psíquico em mulheres e homens (SANTOS, 2009; ZANELLO; BUKOWITZ, 2012). Para que essa articulação seja possível, Maluf (2010) menciona alguns pontos essenciais a esta discussão:

1. Elaboração de uma avaliação sobre as práticas institucionais que reforçam a desigualdade de gênero;

2. Constatação da realidade hipermedicamentosa de mulheres; revisão sobre a política de medicamentos; necessidade de uma política que ofereça outros tratamentos e acompanhamento terapêutico sistemático;

3. Revisão do modelo de cuidado, saúde, doença, sofrimento e cura nas políticas de saúde mental e saúde da mulher.

Essas questões convergem para a relevância da criação de um espaço que propicie a participação social, proporcione o protagonismo de usuários, usuárias e profissionais e contribua para um processo formativo permanente de reflexão sobre as práticas no âmbito micropolítico. É premente também a execução de propostas governamentais que não estimulem a distinção sexual, mas questionem os saberes hegemônicos da racionalização médica, em especial, a psiquiatria. Inserir discussões a respeito das relações de gênero e saúde mental, da incorporação da cultura, da compreensão da influência do patriarcado nas relações sociais entre homens e mulheres pode trazer aberturas para o entendimento do sofrimento mental como categoria gendrada, relacional (ZANELLO; BUKOWITZ, 2012).

Ao assumirmos que "gênero" é um termo relacional, estamos valorizando a vida, com vistas à construção de políticas públicas de igualdade e fortalecimento do diálogo, para assim rompermos com a hegemonia de preconceitos e estereótipos construídos no cotidiano sobre o adoecimento psíquico. 


\section{CONSIDERAÇÕES FINAIS}

É importante salientar a existência da vulnerabilidade das mulheres, questão sociocultural e histórica, que se expressa no cotidiano de forma hierárquica e diferencial, gerando perdas simbólicas e materiais, além de desdobramentos das expressões do poder. $\mathrm{O}$ atual modelo de cuidado ainda prioriza a busca por sintoma-solução, ou seja, o espaço para subjetivação é quase nulo ou tende a zero, o que se reflete diretamente nas políticas públicas.

Além disso, a ênfase dos documentos ministeriais na "saúde da mulher, direitos sexuais e reprodutivos" reforça o pensamento relacional entre saúde, mulher e natureza. Isso ressalta a urgência da proposição de uma política voltada para as especificidades de gênero no cenário dos serviços públicos de saúde mental considerando-se as evidências de uma política de diferença de gênero. Essa diferenciação tem contribuído para disseminação do uso de psicotrópicos por mulheres usuárias do serviço público e prevalência de um modelo físicalista e de racionalização médica que reafirma essa diferença (MALUF, 2010).

É inegável que as reformas psiquiátricas abriram muitas possibilidades para repensar o modelo tradicional de assistência, porém é necessário investir na rede de atenção psicossocial, com financiamento e investimento na formação, em uma perspectiva da educação permanente, não pontual, mas em um continuum. Dessa forma, é possível, juntamente com a construção de políticas públicas que contemplem a questão das relações de gênero, deslocar o discurso médico hegemônico de compreensão da loucura com base na medicação para o entendimento de que a reforma é um processo que vai além da organização dos serviços.

Repensar a reforma psiquiátrica sob esta ótica implica trazer, dos bastidores para a cena, a saúde mental e as relações de gênero, o que requer transformações nas esferas da cultura, das leis, das práticas políticas. Somente assim será possível conceber o sofrimento psíquico não mais como doença mental ou de alta periculosidade, mas como decorrente de diversidades na sociedade, das diferenças sexuais, dos preconceitos e estereótipos presentes nas práticas sociais cotidianas. 


\section{REFERÊNCIAS}

AMARANTE, Paulo. (1995). Loucos pela vida: a trajetória da reforma psiquiátrica no Brasil. Rio de Janeiro: Fiocruz.

AMARANTE, Paulo. (1994). Asilos, alienados, alienistas: uma pequena história da psiquiatria no Brasil. In: Psiquiatria social e reforma psiquiátrica. Rio de Janeiro: Fiocruz.

ANDRADE, Ana Paula Müller de. (2010). O gênero no movimento da reforma psiquiátrica. In: MALUF, Sônia Weidner; Tornquist, Carmem Susana (Orgs.). Gênero, saúde e aflição: abordagens antropológicas. Santa Catarina: Letras Contemporâneas. p. 273-293.

BARROS, Sônia et al. (2014). Censo Psicossocial dos Moradores em Hospitais Psiquiátricos do Estado de São Paulo: um olhar sob a perspectiva racial. Saúde e Sociedade, São Paulo, v. 23, n. 4. Disponível em: <http://dx.doi.org/10.1590/S0104-12902014000400010〉. Acesso em: 22 abr. 2015.

BARROS, Sônia; BICHAFF, Regina. (2008). Desafios para a desinstitucionalização: Censo Psicossocial dos Moradores em Hospitais Psiquiátricos do Estado de São Paulo. São Paulo: FUNDAP. Disponível em: <http://www.saude.sp.gov.br/resources/ses/perfil/profissional-dasaude/grupo-tecnico-de-acoes-estrategicas-gtae/saude-mental/censopsicossocial/censo_psicossocial.pdf>. Acesso em: 11 mar. 2015.

BASAGLIA, Franco. (2005). Escritos selecionados em saúde mental e reforma psiquiátrica. Rio de Janeiro: Garamond.

BASAGLIA, Franco. (1987). Mujer, Locura y Sociedad. México: Universidad Autónoma de Puebla.

BRASIL. (2012). Saúde Mental em Dados - 11, ano VII, n. 11. Brasília: Ministério da Saúde/ SAS/DAPES/ Coordenação Geral de Saúde Mental, Álcool e Outras Drogas. Disponível em: <http://www.saude.gov.br/bvs/saudemental>. Acesso em: 22 abr. 2015.

BRASIL. (2007). Saúde Mental no SUS: acesso ao tratamento e mudança do modelo de atenção. Relatório de Gestão 2003-2006. Brasília: Ministério da Saúde/Secretaria de Atenção à Saúde/DAPE. Disponível em:

<http://bvsms.saude.gov.br/bvs/publicacoes/relatorio_gestao_saude_mental_2003-2006.pdf>. Acesso em: 22 abr. 2015.

BRASIL. (2001). Lei n. 10.216, de 6 de abril de 2001. Dispõe sobre a proteção e os direitos das pessoas portadoras de transtornos mentais e redireciona o modelo assistencial em saúde mental. Diário Oficial da União. Brasília: Ministério da Saúde. Disponível em: <http://www.planalto.gov.br/ccivil_03/leis/LEIS_2001/L10216.htm>. Acesso em: 23 abr. 2016.

BUTLER, Judith. (2014). Regulações de gênero. Cadernos Pagu, n. 42, p. 249-274.

Disponível em: <http://www.scielo.br/pdf/cpa/n42/0104-8333-cpa-42-00249.pdf>. Acesso em: 11 mar. 2015. 
CASARES, Aurelia Martín (2008). Antropología del género: culturas, mitos y esteriotipos sexuales. Madrid: Cátedra.

CHESLER, Phyllis. (1989). Women and madness. New York: Harvest Books.

CORRÊA, Sônia. (2002). Gênero e saúde: campo em transição. In: BRUSCHINI, Cristina; UNBEHAUM, Sandra (Orgs.). Gênero, democracia e sociedade brasileira. São Paulo: Editora 34. p. 357-388.

CUNHA, Maria Clementina Pereira da. (1989). Loucura, gênero feminino: as mulheres do Juquery na São Paulo do início do século XX. Revista Brasileira de História, v. 9, n. 18, p. 121-144. Disponível em: <file:///C:/Users/User/Downloads/mariaclementina.pdf>. Acesso em: 11 mar. 2015.

DEL PRIORE, Mary. (2014). Histórias e conversas de mulher. São Paulo: Planeta.

DEL PRIORE, Mary. (1999). Viagem pelo imaginário do interior feminino. Revista Brasileira de História, v. 19, n. 37. Disponível em: <http://dx.doi.org/10.1590/S010201881999000100009>. Acesso em: 22 abr. 2015.

DESVIAT, Manuel. (1999). A reforma psiquiátrica. Rio de Janeiro: Fiocruz.

DIMENSTEIN, Magda. (2011). Reforma psiquiátrica: integrando experiências brasileiras e espanholas no cuidado integral e territorializado em saúde mental. Estudos de Psicologia, v. 16, n. 3, p. 285-288. Disponível em: <http://www.scielo.br/pdf/epsic/v16n3/11.pdf>. Acesso em: 11 mar. 2015.

ENGEL, Magali. (2007). Psiquiatria e feminilidade. In: DEL PRIORE, Mary (Org.). História das mulheres no Brasil. São Paulo: Contexto. p. 323-360.

FACCHINETTI, Cristiana; RIBEIRO, Andréa; MUNOZ, Pedro F. de (2008). As insanas do Hospício Nacional de Alienados (1900-1939). História, Ciências, Saúde - Manguinhos, v. 15, supl., p. 231-242. Disponível em: <http://dx.doi.org/10.1590/S0104-59702008000500012〉. Acesso em: 22 abr. 2015.

FOUCAULT, Michel. (2006). O poder psiquiátrico: curso dado ao Collège de France (19731974). São Paulo: Martins Fontes.

FOUCAULT, Michel. (1997). Resumos dos cursos do Collège de France (1970-1982). Rio de Janeiro: Jorge Zahar Ed.

FOUCAULT, Michel. (1991). História da Loucura. São Paulo: Perspectiva.

FOUCAULT, Michel. (1979). Microfísica do poder. Rio de Janeiro: Edições Graal.

FOUCAULT, Michel. (1978). História da Loucura na Idade Clássica. São Paulo: Perspectiva.

FRICHE, Izabel Christina Passos; FONSECA, Mônica Beato Soares da. (2003). Concepções e práticas sociais em torno da loucura: alcance e atualidade da História da Loucura de Foucault para investigações etnográficas. Psychê, Universidade São Marcos, São Paulo, v. VII, n. 12, p. 137-158. 
GARCIA, Carla Cristina. (1995). Ovelhas na névoa: um estudo sobre as mulheres e a loucura. Rio de Janeiro: Record; Rosa dos Tempos.

GOFFMAN, Erving. (2010). Manicômios, prisões e conventos. São Paulo: Perspectiva.

GOMES, Maria Paula Cerqueira et al. (2002). Censo dos pacientes internados em uma instituição asilar no Estado do Rio de Janeiro: dados preliminares. Cadernos de Saúde Pública, v. 18, n. 6, p. 1803-1807.

LAQUER, Thomas Walter. (2001). Sexo: corpo e gênero dos gregos a Freud. Rio de Janeiro: Relume-Dumará.

MACHADO, Lia Zanotta. (1998). Gênero, um novo paradigma? Cadernos Pagu, n. 11, p. 107-125. Disponível em:

<file:///C:/Users/User/Downloads/cadpagu_1998_11_10_MACHADO.pdf>. Acesso em: 11 mar. 2015.

MACHADO, Roberto. (2007). Foucault, a ciência e o saber. Rio de Janeiro: Zahar.

MACHADO, Roberto; LOUREIRO, Ângela; LUZ, Rogério; MURICY, Kátia. (1978).

Danação da norma: medicina social e constituição da psiquiatria no Brasil. Rio de Janeiro: Graal.

MALUF, Sônia. (2010). Gênero, saúde e aflição: políticas públicas, ativismo e experiências sociais. In: MALUF, Sônia; TORNQUIST, Carmen (Orgs). Gênero, saúde e aflição abordagens antropológicas. Santa Catarina: Letras Contemporâneas. p. 21-67.

NASCIMENTO, Wanderson Flor do; ZANELLO, Valeska. (2014). Uma história do silêncio sobre gênero e loucura (Parte I) - Sobre o que não se fala em uma arqueologia do silêncio: as mulheres em História da Loucura. In: ZANELLO, Valeska; ANDRADE, Ana Paula Müller de (Orgs). Saúde mental e gênero: diálogos, práticas e interdisciplinaridade. Curitiba: Appris. p. 17-28.

NUNES, Sílvia Alexim. (2010). História e psiquiatria no Brasil da Primeira República. História, Ciências, Saúde - Manguinhos, v. 17, n. 2, p. 373-389. Disponível em: <http://dx.doi.org/10.1590/S0104-59702010000600006>. Acesso em: 11 mar. 2015.

ODA, Ana Maria Galdini Raimundo; DALGALARRONDO, Paulo. (2005). História das primeiras instituições para alienados no Brasil. História, Ciências, Saúde - Manguinhos, v. 12, n. 3, p. 983-1010. Disponível em: <http://www.scielo.br/pdf/hcsm/v12n3/19.pdf>. Acesso em: 22 abr. 2015.

PERROT, Michelle. (2013). Minha história das mulheres. São Paulo: Contexto.

PESSOTI, Isaías. (1999). Os nomes da loucura. São Paulo: Editora 34.

PESSOTI, Isaías. (1996). O século dos manicômios. São Paulo: Editora 34.

PESSOTI, Isaías. (1994). A loucura e as épocas. Rio de Janeiro: Editora 34. 
PITTA, Ana Maria Fernandes (2010). Um balanço da reforma psiquiátrica brasileira: instituições, atores e políticas. Ciência e Saúde Coletiva, v. 16, n. 12, p. 4579-4589. Disponível em: <http://www.scielo.br/pdf/csc/v16n12/02.pdf>. Acesso em: 22 abr. 2015.

PITTA, Ana Maria Fernandes et al. (2004). Censo clínico e psicossocial da população internada em hospitais psiquiátricos do Estado da Bahia: relatório final. Salvador: [s.n.].

RESENDE, Heitor. (2007). Políticas de saúde mental no Brasil: uma visão histórica. In: COSTA, Nilson do Rosário; TUNDIS, Silvério (Orgs.). Cidadania e loucura: políticas de Saúde Mental no Brasil. Rio de Janeiro: Abrasco; Vozes. p. 15-73.

ROHDEN, Fabíola (2001). Uma ciência da diferença: sexo e gênero na medicina da mulher. Rio de Janeiro: Fiocruz.

ROTELLI, Franco; LEONARDIS, Ota; MAURI, Diana; RISIO, C. (1990). Desinstitucionalização, uma outra via. In: NICÁCIO, Fernanda (Org.).

Desinstitucionalização. São Paulo: Hucitec. p. 17-59.

SANTOS, Anna Maria Corbi Caldas dos. (2009). Articular saúde mental e relações de gênero: dar voz aos sujeitos silenciados. Ciência e Saúde Coletiva, v. 14, n. 4, p. 1177-1182.

Disponível em: <http://dx.doi.org/10.1590/S1413-81232009000400023>. Acesso em: 22 abr. 2015.

SARACENO, Benedetto. (1999). Libertando identidades: da reabilitação psicossocial à cidadania possível. Rio de Janeiro: Instituto Franco Basaglia; Te Corá.

SHOWALTER, Elaine. (1995). Histórias histéricas: a histeria e a mídia moderna. Rio de Janeiro: Rocco.

SHOWALTER, Elaine. (1985). The female malady: women, madness, an English culture, 1830-1980. London: Penguin Books.

SZASZ, Thomas Stephen. (1976). A fabricação da loucura. Rio de Janeiro: Zahar.

TOSI, Lucía. (1998). Mulher e ciência: a revolução científica, a caça às bruxas e a ciência moderna. Cadernos Pagu, n. 10, p. 369-397. Disponível em:

<file:///C:/Users/User/Downloads/cadpagu_1998_10_14_TOSI.pdf>. Acesso em: 11 mar. 2015.

WADI, Yonissa Marmitt (2006). Experiências de vida, experiências de loucura: algumas histórias sobre mulheres internas no Hospício São Pedro (Porto Alegre, RS, 1884-1923). História Unisinos, v. 10, n.1, p. 65-79. Disponível em: <file:///C:/Users/User/Downloads/6171-18852-1-SM\%20(1).pdf>. Acesso em: 22 abr. 2015.

ZANELLO, Valeska. (2010). Mulheres e loucura: questões de gênero para a psicologia clínica. In: STEVENS, Cristina; BRASIL, Kátia Cristina Tarouquella; ALMEIDA, Tânia Mara Campos de; ZANELLO, Valeska (Org.). Gênero e feminismos: convergências (in)disciplinares. Brasília: Ex Libris, 2010. p. 307-320.

ZANELLO, Valeska; BUKOWITZ, Bruna. (2012). Loucura e cultura: uma escuta das relações de gênero nas falas de pacientes psiquiatrizados. Revista Labrys Estudos Feministas. 
Disponível em: <http://www.tanianavarroswain.com.br/labrys/labrys20/bresil/valeska.htm>. Acesso em: 22 abr. 2015.

ZANELLO, Valeska; SILVA, René Marc Costa e. (2012). Saúde mental, gênero e violência estrutural. Revista Bioética, Brasília, v. 20, n. 2, p. 267-279. Disponível em:

<http://revistabioetica.cfm.org.br/index.php/revista_bioetica/article/view/745/776>. Acesso em: 22 abr. 2015.

ZANELLO, Valeska; FONSECA, Gabriela Macedo Pinheiro da; ROMERO, Ana Carolina. (2011). Entrevistas de evolução psiquiátricas: entre a "doença mental" e a medicalização. Mental e Psicologia, v, 8, n. 16, p. 621-640. Disponível em:

<http://issuu.com/zeppelini/docs/rmpv9n17>. Acesso em: 8 abr. 2015. 


\section{ARTIGO 2 - SAÚDE MENTAL E GÊNERO: O PERFIL SOCIODEMOGRÁFICO DE PACIENTES EM UM CENTRO DE ATENÇÃO PSICOSSOCIAL}

RESUMO: Os Centros de Atenção Psicossocial (CAPS) são considerados serviços de saúde mental inovadores no contexto das políticas públicas brasileiras. Objetivamos neste estudo caracterizar, comparar e analisar o perfil sociodemográfico de mulheres e homens de um CAPS II, localizado em Brasília, admitidos entre os anos de 2012 e 2013, com base na perspectiva de gênero como construção social e cultural. Estudo transversal, de abordagem quantitativa, com produção de dados por análise de prontuários de mulheres e homens, a partir da ficha de acolhimento e evolução psiquiátrica. Os resultados demonstraram significativa presença feminina nesse serviço e evidenciaram características comuns entre os sexos, como baixos níveis de renda e escolarização, além de ocupações predominantemente baseadas nas diferenças de gênero. Reforçam, ainda, as desigualdades sociais e a precariedade da categoria "trabalho" na vida dos usuários/as, bem como a necessidade de projetos que valorizem a economia solidária como alternativa de trabalho e geração de renda. Investimentos em políticas públicas transversais, especialmente na educação permanente de profissionais da equipe de saúde mental, em uma perspectiva de gênero, também se mostraram necessários.

Palavras-chave: saúde mental; mulheres; gênero; condições sociais.

ABSTRACT: The Centers of Psycho-Social Attention (CAPS) are considered innovative mental health services in the context of Brazilian public policies. This study aimed to describe, contrast, and analyze the socio-demographic profile of women and men receiving services from a CAPS II in a Brazilian capital, assessed by the intake protocol. This crosssectional study, in a quantitative approach, and considered the gender perspective as a social and cultural construction. Results showed significant presence of female receiving this service and exposed common characteristics among male and female users, such as low levels of income and education, and occupations mainly based on gender differences. These findings reinforce social inequalities and precariousness of work in the lives of users and display the need for projects that foster the solidarity economy as a source of employment and income. 
Investments in transversal public policy, especially in training of mental health professionals, in a perspective of gender, also showed to be necessary.

Keywords: mental health; women; gender; social conditions.

RESUMEN: Los Centros de Atención Psicosocial (CAPS) son considerados servicios de salud mental innovadores en el contexto de las políticas públicas brasileñas. Este estudio tuvo como objetivo caracterizar, comparar y analizar el perfil sociodemográfico de las mujeres y de los hombres de un CAPS II, ubicado en el Distrito Federal, con base en la perspectiva de género como construcción social y cultural. Estudio transversal de enfoque cuantitativo, con producción de los datos por análisis de los prontuarios de las mujeres y los hombres, desde el protocolo de acogida. Los resultados mostraron presencia femenina significativa en este servicio y mostraron características comunes entre los sexos, como los bajos niveles de renta y de educación, además de las ocupaciones predominantemente basadas en las diferencias de género. Refuerzan aún las desigualdades sociales y la precariedad de la categoría trabajo en la vida de los usuarios/as, así como la necesidad de proyectos que valoricen la economía solidaria como una fuente de empleo y generación de renta. Los investimentos en las políticas públicas transversales, sobre todo en la formación continuada de los profesionales del equipo de salud mental, en una perspectiva de género, también resultaron necesario.

Palabras-clave: salud mental; mujeres; género; condiciones sociales. 


\section{INTRODUÇÃO}

As transformações das práticas e do paradigma psiquiátrico no contexto da saúde mental abriram um novo campo de possibilidades e de formulação de políticas de saúde mental (AMARANTE, 1995; ALVERGA; DIMENSTEIN, 2006; DEVERA; COSTA-ROSA, 2007; TENÓRIO, 1994). Essas mudanças implicaram a construção de um modelo cuja característica central é o cuidado em saúde mental territorial, realizado pelos Centros de Atenção Psicossocial (CAPS). Esses serviços inseridos na gestão pública são considerados a principal estratégia política e têm como desafio a desinstitucionalização (ROTELLI et al., 1990).

A Política Nacional de Saúde Mental preconiza várias tipificações de CAPS: CAPS I, II e III; CAPS infantil; CAPS álcool e outras drogas (ad) e CAPSad III. Esses centros ofertam diversos tipos de atividades terapêuticas intermediadas por uma equipe multiprofissional responsável por psicoterapia individual ou em grupo, acolhimento, oficinas terapêuticas, atividades comunitárias, atividades artísticas, orientação e acompanhamento do uso de medicação, atendimento domiciliar e aos familiares. Essas ações estão articuladas por projeto terapêutico singular e na perspectiva da reabilitação psicossocial (BRASIL, 2004).

Dentre as atividades terapêuticas, destaca-se o acolhimento aos usuários/as como um dos eixos importantes de cuidado nos CAPS. É diretriz da Política Nacional de Humanização $(\mathrm{PNH})$ e pode ser realizado em dias não pré-determinados e por profissional não específico e especializado para executá-lo. Trata-se do primeiro contato do usuário com o serviço, momento em que lhe é explicado aquilo que é oferecido, e de que forma. Além disso, caracteriza-se como uma oportunidade para triar a demanda, ou seja, definir, após avaliação do profissional, se o caso é pertinente ao CAPS e, se não for, quais as possibilidades de atendimento na rede de serviços para essa pessoa.

Segundo Franco, Bueno e Merhy (1999), o acolhimento propõe inverter a lógica de organização e funcionamento do serviço de saúde, com base nos seguintes princípios: 1) atender a todas as pessoas que procuram os serviços de saúde, garantindo a acessibilidade universal; 2) reorganizar o processo de trabalho, deslocando o seu eixo do médico para uma equipe multiprofissional; 3) qualificar a relação trabalhador-usuário, com vistas a conferir parâmetros humanitários de solidariedade e cidadania. 
Dessa forma, o acolhimento deve ser visto como aspecto vital no processo de trabalho e garantia do acesso universal e resolutivo à população, princípios básicos do SUS. Portanto, segundo Schmidt e Figueiredo (2009), o acolhimento utilizado como técnica pela equipe interdisciplinar pode produzir capacidades de resposta ao usuário, à medida em que a equipe multiprofissional considera a importância de superar a fragmentação dos saberes e buscar novas respostas às demandas emergentes das pessoas que procuram os serviços de saúde.

Atender as demandas emergentes dos usuários/as implica o reconhecimento pela equipe técnica do acolhimento como um ato de cuidado no campo da Saúde Mental, descrito como a essência do trabalho no cotidiano (YASUI, 2007). Sugere, portanto, uma atitude de preocupação e envolvimento com o outro, o que configura uma ruptura do paradigma clínico tradicional baseado na relação mecânica causa-efeito na análise do adoecimento psíquico (ROTELLI et al., 1990), para a busca incessante do novo paradigma, que contempla a adoção de um olhar para o contexto e os recursos dos usuários/as (VASCONCELOS, 2014).

Na perspectiva do acolhimento, a realização de análises sociodemográficas, tendo os CAPS como cenário de pesquisas, pode melhor dimensionar a necessidade e o caráter das ações em saúde com base no conhecimento da demanda, não somente clínica, mas também das condições sociais daqueles que procuram por serviços de saúde mental. Essas análises envolvem variáveis complexas, principalmente quando associadas a políticas econômicas e sociais, renda, posses, situação de vida, ocupação e educação. No entanto, por não serem equivalentes, essas medidas podem ter distintos significados e representar conceitos diferentes de status social em culturas variadas (ARAYA et al., 2003). Além disso, quando estudadas em associação aos transtornos mentais comuns (TMC) cujos sintomas são insônia, fadiga, irritabilidade, esquecimento, dificuldades de concentração e queixas somáticas (GOLDBERG; HUXLEY, 1992), demonstram os desdobramentos da desvantagem social, falta de bens materiais, baixa renda e dificuldades financeiras em países ocidentais.

Embora a ênfase deste artigo não seja nos sintomas dos TMC (Transtornos Mentais Comuns), observamos e destacamos que são os mais frequentemente relatados durante o momento de acolhimento, especialmente por mulheres usuárias do CAPS II do Distrito Federal, cenário desta pesquisa. Destacamos que, diante da escassez de estudos sociodemográficos em CAPS II, para desenvolvimento deste estudo, optamos por realizar e apresentar uma análise, na perspectiva de gênero e saúde mental, de dados sociodemográficos de homens e mulheres, com base nas informações de prontuários, especialmente do protocolo de entrevista inicial: a ficha de acolhimento de homens e mulheres. 
Nesse sentido, importa mencionar a perspectiva de gênero e saúde mental com a qual trabalhamos nesse estudo. Em nossa cultura binária (homem/mulher), certas diferenças físicas (sexuais) são eleitas para justificar a ocupação de certos espaços (simbólicos e concretos, de maior ou menos poder) sociais (LAQUEUR, 2001). O gênero, como categoria relacional (SCOTT, 1996), atravessa as instituições e suas estruturas, assim como as práticas cotidianas. Essas relações estão imbricadas em relações de poder (GROSSI et al., 1998). Através de diversos dispositivos, a cultura privilegia caminhos de subjetivação diferentes para homens e mulheres (ZANELLO, prelo) e, também, de adoecimento psíquico (ZANELLO e BUKOWITZ, 2011).

Fazer uma releitura da saúde mental sob a perspectiva de gênero pressupõe, portanto, a compreensão da participação dos fatores socioculturais e sociodemográficos na experiência do sofrimento psíquico.

\section{MÉTODO}

Trata-se de um estudo transversal, quantitativo (CRESWELL, 2013), baseado em prontuários de homens e mulheres atendidos no Centro de Atenção Psicossocial (CAPS II), em Brasília. Os dados foram coletados a partir das fichas de acolhimento e anamnese psiquiátrica de todos os usuários/as admitidos entre os anos de 2012 e 2013, totalizando 234 prontuários, sendo 169 mulheres e 65 homens.

Como exclusão foram adotados os seguintes critérios: usuários/as que não deram continuidade ao tratamento e cujas fichas de acolhimento e evolução psiquiátrica se encontravam no arquivo permanente do serviço; prontuários que apresentaram apenas a ficha de acolhimento e uma consulta do clínico geral do CAPS (geralmente de usuários/os que ainda irão passar pela avaliação psiquiátrica); usuários/as que, equivocadamente, encontravam-se no arquivo de ativos, porém não apresentavam anamnese psiquiátrica e evolução psiquiátrica, somente o registro do médico clínico geral desse serviço; e as fichas sem o correto preenchimento sociodemográfico.

Todas as fichas elegíveis de acolhimento e evoluções psiquiátricas da população foram digitalizadas, utilizando um scanner portátil com base de mesa digitalizadora. As variáveis analisadas, presentes na ficha de acolhimento foram: faixa etária: em intervalos de 9 anos, a 
partir de 18 anos; estado civil: consideramos união estável como casado; religião: católica, protestante, espírita, outra, nenhuma e não consta; escolaridade: analfabeto, ensino fundamental, ensino médio, ensino superior, ensino especial e não consta; número de filhos: de 1 a 6, incluindo os itens "não tem" e "não consta"; renda familiar per capita mensal, definida como renda familiar total em salários mínimos, com as atualizações monetárias dos anos de 2012 e 2013; trabalho: afastado, desempregado, doméstico não remunerado, remunerado (formal), informal, não trabalha, outro e não consta; ocupação: dona de casa, estudante, profissões de nível médio, nível superior, outros e não consta; benefícios: aposentadoria, pensionista, auxílio-doença, Benefício de Prestação Continuada, outros, não recebe e não consta; encaminhamentos para o CAPS e área de abrangência (local do domicílio) do usuário/a. Optamos por considerar a informação sociodemográfica da anamnese psiquiátrica após conferência de todas as fichas, por se tratar da última atualização.

Os dados referentes a todas as fichas foram digitados em um banco de dados Microsoft Access para posterior análise. Utilizou-se análise descritiva por meio de frequências absolutas e percentuais e teste $\chi^{2}$ para a comparação entre as categorias. O nível de significância foi de 95\%. Elaboramos, ainda, um levantamento de temas recorrentes nos prontuáriosdos pacientes.

A pesquisa foi aprovada pelo Comitê de Ética em Pesquisa (CEP) do Instituto de Ciências Humanas ( $\mathrm{ICH})$ da Universidade de Brasília, por meio do Protocolo $\mathrm{n}^{\circ}$ $692.165 / 2014$.

\section{RESULTADOS}

Foram coletadas fichas de um total de 234 usuários, sendo 169 mulheres $(72,22 \%)$ e 65 homens (27,77\%), admitidos entre os anos de 2012 e 2013. A Tabela 1 descreve os totais e percentuais da faixa etária, situação conjugal, escolaridade, religião e quantitativo de filhos, segundo sexo. As categorias apresentadas nesta tabela foram significativamente diferentes.

A faixa etária entre 35 a 44 anos foi a que apresentou maior proporção, tanto para mulheres $(34,3 \%)$ quanto para homens $(29,2 \%)$, embora a segunda classe com maior proporção tenha sido a imediatamente superior para as mulheres (45 a 54 anos) e a inferior para os homens (24 a 34 anos), levando à observação de tendência de maior idade para as mulheres quando comparada aos homens. 
No que se refere à situação conjugal, ainda que observada maior proporção de mulheres casadas (37,3\%), quando comparada as demais categorias (solteira, separada e viúva), as diferenças entre elas não eram tão grandes quando comparadas com os homens na categoria solteiros $(58,5 \%)$, que representava mais da metade das observações.

Em relação à escolaridade, encontramos que 48,7\% das pessoas eram analfabetas ou possuíam o ensino fundamental, sendo que, das mulheres, a proporção era de $46,1 \%$ e dos homens, $55,4 \%$. Apenas $8,5 \%$ das pessoas tinham ensino superior, sendo que das mulheres, esta proporção era de $8,9 \%$ e dos homens, $7,7 \%$.

Dos que declararam seguir uma religião, a Protestante foi a que teve maior declaração, seguida pela Católica. Porém, a grande parte das pessoas não declararam a sua religião, ou não tinham nenhuma religião ou mesmo professavam outras que não estavam relacionadas.

A maior parte das mulheres eram mães, com poucos filhos, de 1 ou 2 filhos (47,9\%), e apenas $18,3 \%$ delas declararam não ter filhos. Para os homens, a grande maioria declarou não ter filhos $(52,3 \%)$.

Na Tabela 1, todas as variáveis tiveram resultados significativos para o teste do quiquadrado, tanto para as mulheres quanto para os homens, portanto as distribuições entre classes não foram aleatórias. 
Tabela 1 - Distribuição dos totais e percentuais da faixa etária, situação conjugal, escolaridade, religião e quantitativo de filhos, segundo sexo.

\begin{tabular}{|c|c|c|c|c|c|c|c|c|c|}
\hline \multirow{2}{*}{ Categorias } & \multicolumn{3}{|c|}{ Feminino } & \multicolumn{3}{|c|}{ Masculino } & \multicolumn{3}{|c|}{ Total } \\
\hline & $\mathrm{N}$ & $(\%)$ & $\mathrm{p}$ & $\mathrm{N}$ & $(\%)$ & $\mathrm{p}$ & $\mathrm{N}$ & $(\%)$ & $\mathrm{p}$ \\
\hline Faixa etária (anos) & & & $<0,001$ & & & $<0,001$ & & & $<0,001$ \\
\hline $18-24$ & 4 & $2,4[0,1-4,7]$ & & 9 & $13,8[5,4-22,2]$ & & 20 & $8,6[5-12,2]$ & \\
\hline $25-34$ & 24 & $14,2[8,9-19,5]$ & & 18 & $27,7[16,8-38,6]$ & & 39 & $16,7[11,9-21,5]$ & \\
\hline $35-44$ & 58 & $34,3[27,2-41,5]$ & & 19 & $29,2[18,2-40,3]$ & & 73 & $31,3[25,4-37,3]$ & \\
\hline $45-54$ & 49 & $29[22,2-35,8]$ & & 13 & $20[10,3-29,7]$ & & 58 & $24,9[19,3-30,4]$ & \\
\hline $55-64$ & 29 & $17,2[11,5-22,8]$ & & 5 & $7,7[1,2-14,2]$ & & 36 & $15,5[10,8-20,1]$ & \\
\hline 65 e mais & 5 & $3[0,4-5,5]$ & & 1 & $1,5[0-4,5]$ & & 7 & $3[0,8-5,2]$ & \\
\hline Situação conjugal & & & $<0,001$ & & & $<0,001$ & & & $<0,001$ \\
\hline Solteiro (a) & 45 & $26,6[20-33,3]$ & & 38 & $58,5[46,5-70,4]$ & & 83 & $35,5[29,3-41,6]$ & \\
\hline Casado (a) & 63 & $37,3[30-44,6]$ & & 18 & $27,7[16,8-38,6]$ & & 81 & $34,6[28,5-40,7]$ & \\
\hline Separado (a) & 50 & $29,6[22,7-36,5]$ & & 8 & $12,3[4,3-20,3]$ & & 58 & $24,8[19,3-30,3]$ & \\
\hline Viúvo (a) & 11 & $6,5[2,8-10,2]$ & & 1 & $1,5[0-4,5]$ & & 12 & $5,1[2,3-8]$ & \\
\hline Escolaridade & & & $<0,001$ & & & $<0,001$ & & & $<0,001$ \\
\hline Analfabeto (a) & 8 & $4,7[1,5-7,9]$ & & 6 & $9,2[2,2-16,3]$ & & 14 & $6,0[2,9-9,0]$ & \\
\hline $\begin{array}{l}\text { Ensino } \\
\text { Fundamental }\end{array}$ & 70 & $41,4[34-48,8]$ & & 30 & $46,2[34-58,3]$ & & 100 & $42,7[36,4-49,1]$ & \\
\hline Ensino médio & 70 & $41,4[34-48,8]$ & & 20 & $30,8[19,5-42]$ & & 90 & $38,5[32,2-44,7]$ & \\
\hline Ensino superior & 15 & $8,9[4,6-13,2]$ & & 5 & $7,7[1,2-14,2]$ & & 20 & $8,5[5,0-12,1]$ & \\
\hline $\begin{array}{l}\text { Sem } \\
\text { informação/outros }\end{array}$ & 6 & $3,6[0,8-6,3]$ & & 4 & $6,2[0,3-12]$ & & 10 & $4,3[1,7-6,9]$ & \\
\hline
\end{tabular}




\begin{tabular}{|c|c|c|c|c|c|c|c|c|c|}
\hline \multirow{2}{*}{ Categorias } & \multicolumn{3}{|c|}{ Feminino } & \multicolumn{3}{|c|}{ Masculino } & \multicolumn{3}{|c|}{ Total } \\
\hline & $\mathrm{N}$ & $(\%)$ & $\mathrm{p}$ & $\mathrm{N}$ & $(\%)$ & $\mathrm{p}$ & $\mathrm{N}$ & $(\%)$ & $\mathrm{p}$ \\
\hline Religião & & & $<0,001$ & & & $<0,001$ & & & $<0,001$ \\
\hline Católica & 27 & $16,0[10,5-21,5]$ & & 10 & $15,4[6,6-24,2]$ & & 37 & $15,8[11,1-20,5]$ & \\
\hline Protestante & 44 & $26,0[19,4-32,7]$ & & 14 & $21,5[11,5-31,5]$ & & 58 & $24,8[19,3-30,3]$ & \\
\hline Espírita & 4 & $2,4[0,1-4,7]$ & & 2 & $3,1[0,0-7,3]$ & & 6 & $2,6[0,5-4,6]$ & \\
\hline $\begin{array}{l}\text { Sem } \\
\text { inf/outras/nenhuma }\end{array}$ & 94 & $55,6[48,1-63,1]$ & & 39 & $60,0[48,1-71,9]$ & & 133 & $56,8[50,5-63,2]$ & \\
\hline Quantitativo de filhos & & & $<0,001$ & & & $<0,001$ & & & $<0,001$ \\
\hline Sem filhos & 31 & $18,3[12,5-24,2]$ & & 34 & $52,3[40,2-64,5]$ & & 65 & $27,8[22-33,5]$ & \\
\hline 1 filho & 34 & $20,1[14,1-26,2]$ & & 8 & $12,3[4,3-20,3]$ & & 42 & $17,9[13-22,9]$ & \\
\hline 2 filhos & 47 & $27,8[21,1-34,6]$ & & 9 & $13,8[5,4-22,2]$ & & 56 & $23,9[18,5-29,4]$ & \\
\hline 3 filhos & 33 & $19,5[13,6-25,5]$ & & 5 & $7,7[1,2-14,2]$ & & 38 & $16,2[11,5-21]$ & \\
\hline 4 e mais filhos & 18 & $10,7[6-15,3]$ & & 5 & $7,7[1,2-14,2]$ & & 23 & $9,8[6-13,6]$ & \\
\hline Sem informação & 6 & $3,6[0,8-6,3]$ & & 4 & $6,2[0,3-12]$ & & 10 & $4,3[1,7-6,9]$ & \\
\hline
\end{tabular}


Sobre as variáveis "trabalho", "renda", "benefícios sociais e de saúde" e "ocupação", os dados indicam várias relações com a saúde mental (Tabela 2). A proporção de 58,6\% das mulheres declararam trabalhar em ambiente doméstico, de forma remunerada ou não, enquanto que $56,9 \%$ dos homens estavam desempregados ou não trabalhavam.

Descrição sobre a Renda Familiar foi marcada pela categoria "Sem informação", tanto para as mulheres $(56,8 \%)$ quanto para os homens $(50,8 \%)$. A maior parte, tanto dos homens quanto das mulheres, cujos prontuários continham esta informação, declarou estar situados em uma faixa de 1 a 3 salários mínimos.

Informações sobre Benefícios também foi semelhante à Renda, quanto a classe "Sem informação", mulheres, 58,6\% e homens 49,2\%. Entre as mulheres, predominou o "Auxíliodoença", com 17,2\%, enquanto que para os homens, "Não recebe", com 16,9\%.

No que se refere à ocupação, apontam que 31,4\% de mulheres eram donas de casa, enquanto nenhum homem exercia essa função. Dentre os homens predominou a classe “Outros", com 55,4\%.

$\mathrm{Na}$ Tabela 2, todas as variáveis tiveram resultados significativos para o teste do quiquadrado, com exceção da variável "Benefício" para os homens. 
Tabela 2 - Distribuição dos totais e percentuais da situação de trabalho, renda familiar, benefícios e ocupação, segundo sexo.

\begin{tabular}{|c|c|c|c|c|c|c|c|c|c|c|}
\hline \multirow[t]{2}{*}{ Categorias } & & \multicolumn{3}{|c|}{ Feminino } & \multicolumn{3}{|c|}{ Masculino } & \multicolumn{3}{|c|}{ Total } \\
\hline & & $\mathrm{N}$ & $(\%)$ & $\mathrm{p}$ & $\mathrm{N}$ & $(\%)$ & $\mathrm{p}$ & $\mathrm{N}$ & $(\%)$ & $\mathrm{p}$ \\
\hline \multirow[t]{8}{*}{ Trabalho } & & & & $<0,001$ & & & $<0,001$ & & & $<0,001$ \\
\hline & Afastado(a)-INSS & 0 & $0[0-0]$ & & 3 & $4,6[0-9,7]$ & & 3 & $1,3[0-2,7]$ & \\
\hline & Desempregado(a) & 17 & $10,1[5,5-14,6]$ & & 14 & $21,5[11,5-31,5]$ & & 31 & $13,2[8,9-17,6]$ & \\
\hline & $\begin{array}{l}\text { Doméstico não } \\
\text { remunerado(a) }\end{array}$ & 50 & $29,6[22,7-36,5]$ & & 0 & $0[0-0]$ & & 50 & $21,4[16,1-26,6]$ & \\
\hline & Remunerado(a) & 49 & $29[22,2-35,8]$ & & 7 & $10,8[3,2-18,3]$ & & 56 & $23,9[18,5-29,4]$ & \\
\hline & Informal & 12 & $7,1[3,2-11]$ & & 13 & $20[10,3-29,7]$ & & 25 & $10,7[6,7-14,6]$ & \\
\hline & Não trabalha & 37 & $21,9[15,7-28,1]$ & & 23 & $35,4[23,8-47]$ & & 60 & $25,6[20-31,2]$ & \\
\hline & $\begin{array}{l}\text { Sem } \\
\text { informação/outros }\end{array}$ & 4 & $2,4[0,1-4,7]$ & & 5 & $7,7[1,2-14,2]$ & & 9 & $3,8[1,4-6,3]$ & \\
\hline \multicolumn{3}{|c|}{ Renda familiar (salário mínimo) } & & $<0,001$ & & & $<0,001$ & & & $<0,001$ \\
\hline & Nenhuma & 1 & $0,6[0-1,7]$ & & 5 & $7,7[1,2-14,2]$ & & 6 & $2,6[0,5-4,6]$ & \\
\hline & $<1$ & 7 & $4,1[1,1-7,2]$ & & 1 & $1,5[0-4,5]$ & & 8 & $3,4[1,1-5,7]$ & \\
\hline & 1 a 3 & 60 & $35,5[28,2-42,8]$ & & 18 & $27,7[16,8-38,6]$ & & 78 & $33,3[27,3$ - 39,4] & \\
\hline & 4 a 7 & 4 & $2,4[0-4,7]$ & & 7 & $10,8[3,2-18,3]$ & & 11 & $4,7[2-7,4]$ & \\
\hline & $>7$ & 1 & $0,6[0-1,8]$ & & 1 & $1,5[0-4,5]$ & & 2 & $0,9[0-2]$ & \\
\hline & Sem informação & 96 & $56,8[49,2-64,4]$ & & 33 & $50,8[38,6-62,9]$ & & 129 & $55,1[48,8-61,5]$ & \\
\hline \multirow[t]{8}{*}{ Benefício } & & & & $<0,001$ & & & 0,08 & & & $<0,001$ \\
\hline & Aposentadoria & 11 & $6,5[2,8-10,2]$ & & 6 & $9,2[2,2-16,3]$ & & 17 & $7,3[3,9-10,6]$ & \\
\hline & Pensionista & 4 & $2,4[0,1-4,7]$ & & 1 & $1,5[0-4,5]$ & & 5 & $2,1[0,3-4]$ & \\
\hline & Auxílio-doença & 29 & $17,2[11,5-22,8]$ & & 5 & $7,7[1,2-14,2]$ & & 34 & 14,5 [10 - 19] & \\
\hline & $\begin{array}{l}\text { Prestação } \\
\text { continuada }\end{array}$ & 3 & $1,8[0-3,8]$ & & 6 & $9,2[2,2-16,3]$ & & 9 & $3,8[1,4-6,3]$ & \\
\hline & Não recebe & 14 & $8,3[4,1-12,4]$ & & 11 & $16,9[7,8-26]$ & & 25 & $10,7[6,7-14,6]$ & \\
\hline & Outros & 9 & $5,3[1,9-8,7]$ & & 4 & $6,2[0,3-12]$ & & 13 & $5,6[2,6-8,5]$ & \\
\hline & Sem informação & 99 & $58,6[51,2-66]$ & & 32 & $49,2[37,1-61,4]$ & & 131 & $56[49,6-62,3]$ & \\
\hline
\end{tabular}




\begin{tabular}{|c|c|c|c|c|c|c|c|c|c|c|}
\hline \multirow[t]{2}{*}{ Categorias } & & \multicolumn{3}{|c|}{ Feminino } & \multicolumn{3}{|c|}{ Masculino } & \multicolumn{3}{|c|}{ Total } \\
\hline & & $\mathrm{N}$ & $(\%)$ & $\mathrm{p}$ & $\mathrm{N}$ & $(\%)$ & $\mathrm{p}$ & $\mathrm{N}$ & $(\%)$ & $\mathrm{p}$ \\
\hline Ocupação & & & & $<0,001$ & & & $<0,001$ & & & $<0,001$ \\
\hline & Dona de casa & 53 & $31,4[24,4-38,4]$ & & 0 & $0[0-0]$ & & 53 & $22,6[17,3-28]$ & \\
\hline & Estudante & 4 & $2,4[0,1-4,7]$ & & 4 & $6,2[0,3-12]$ & & 8 & $3,4[1,1-5,7]$ & \\
\hline & Nível médio & 25 & $14,8[9,4-20,1]$ & & 11 & $16,9[7,8-26]$ & & 36 & $15,4[10,8-20]$ & \\
\hline & Nível superior & 16 & $9,5[5,1-13,9]$ & & 5 & $7,7[1,2-14,2]$ & & 21 & $9[5,3-12,6]$ & \\
\hline & Outros & 54 & $32[24,9-39]$ & & 36 & $55,4[43,3-67,5]$ & & 90 & $38,5[32,2-44,7]$ & \\
\hline & Sem informação & 17 & $10,1[5,5-14,6]$ & & 9 & $13,8[5,4-22,2]$ & & 26 & $11,1[7,1-15,1]$ & \\
\hline
\end{tabular}


Sobre os principais temas recorrentes nos prontuários, emergiram as seguintes questões relacionadas à trajetória de vida, especialmente das mulheres: relações maternais aparecem como ruptura - depois de ter um filho ou depois de perder um filho, como também depois de briga com o filho ou envolvimento do filho com as drogas. Expressões como “dificuldades no cuidado com os filhos", "desejo de matar os filhos", “depressão pós-parto após o nascimento do primeiro filho", "pensamento de agressividade com a filha", "queixa de que os filhos não lhe dão atenção suficiente e não aceita que eles sejam independentes", "início dos sintomas após o falecimento da filha", dentre outras, foram recorrentes nos prontuários das mulheres. A relação com a mãe aparece em quase todos os prontuários das mulheres, ora como dor da perda (morte), ora como relação conflituosa.

Outra questão que parece contribuir para o sofrimento psíquico intenso das mulheres refere-se à conjugalidade, expressa como: "medo do ex-companheiro matá-la", "marido a encarcerava", "vontade de matar o marido", "queixa-se de solidão em relação ao marido", "sente-se abandonada e humilhada pelo marido", "afirma ficar com ele por causa dos filhos". Tais expressões materializam a relação entre conjugalidade e sofrimento. Por outro lado, nos prontuários dos homens aparecem muito pouco esses aspectos, e as descrições das crises psíquicas parecem estreitamente relacionadas aos sintomas descritos pela CID 10, como esquizofrenia. Poucos relatos sobre conflitos familiares, relação conjugal, relação com os filhos e com mãe. As mulheres aparecem nos prontuários dos homens como cuidadoras dos maridos que adoecem e/ou mães cuidadoras de seus filhos que enlouquecem.

Ainda, observamos que a variável "vida laboral prejudicada", aparece tanto em homens, como em mulheres. Notamos que o termo "sobrecargas" apareceu associado ao trabalho das mulheres no âmbito privado, como doméstica e ou cuidadora de pessoas doentes na família.

Também encontramos diferenças perceptíveis na variável "ocupação”, na classificação “outros". Para as mulheres: auxiliar de limpeza”, "auxiliar de serviços gerais”, "auxiliar de supermercado", "babá", "diarista", “costureira", "cozinheira", "lavadeira”, "passadeira" e "doceira". Por outro lado, também exerciam atividades consideradas masculinas: "frentista", "despachante", "porteira" e "manutenção de aeronaves em aeroportos". Para os homens, prevaleceram ocupações tipicamente masculinas: "auxiliar em construção civill, "bicheiro", “auxiliar de depósito", “auxiliar em oficina mecânica", "porteiro”, "lavrador”, “marceneiro", “marinheiro", "pintura em carros", “vigilante”, entre outros. 
Nas ocupações classificadas como de nível superior, percentual maior foi encontrado para as mulheres, em relação aos homens, com predomínio de "professoras". Em alguns prontuários, era citado o termo "cuidadora" relacionado ao trabalho doméstico de quem cuida de pessoas doentes na família, o que gera sobrecarga, cansaço e exaustão.

\section{DISCUSSÃO}

Estudos brasileiros constatam que as mulheres são mais frequentadoras dos serviços públicos de saúde do que os homens (TRAVASSOS et al., 2002; TELLES FILHO et al., 2011). Para Gomes, Nascimento e Araújo (2007), essa diferença associa a pouca procura por serviços de saúde por parte de homens a um modelo hegemônico de masculinidade, relacionado a hábitos de prevenção que usualmente são mais associados às mulheres, ao cuidado de si como expressão da esfera feminina, à relação do ser homem à invulnerabilidade, força e virilidade; à vergonha de ficar exposto ao profissional de saúde; ao medo de descobrir que sua saúde está vulnerável; além da falta de unidades de saúde específicas para acolhimento das demandas dos homens.

Especificamente, sugere-se que a baixa demanda dos homens, no cenário desta pesquisa, pode estar relacionada ao modelo de masculinidade citado acima, nos quesitos "cuidado de si" e "medo de descobertas ruins sobre a sua saúde mental" (GOMES et al., 2007), os quais mascaram o sofrimento psíquico e dificultam o acesso a esse CAPS. Alguns protocolos de acolhimento e evoluções psiquiátricas confirmam a existência da negação da doença pelo usuário e uso irregular da medicação, o que expressa a dificuldade de cuidar de si. Nesse sentido, um deles chamou atenção, por trazer a informação do início dos sintomas ter sido há mais de 20 anos, mas o paciente ter procurado o CAPS apenas em 2001.

Já o alto percentual de mulheres adoecidas e frequentadoras desse CAPS pode apontar a psiquiatrização das mulheres e indicar uma relação direta com as condições por elas enfrentadas em seu cotidiano, com as relações hierarquizadas de gênero, como relações de poder e papéis sociais, de conflito e violência, seja na família, no trabalho ou nos serviços de saúde (CARVALHO; DIMENSTEIN, 2003; ZANELLO; SILVA, 2012; GARCIA, 1994). Pode-se, portanto, afirmar que esse CAPS é um espaço de expressão das subjetividades femininas e suas invisibilidades. Muitas das condições citadas foram expressas nos prontuários, em sua maioria conflitos com a mãe (desentendimentos, perdas e maus tratos) e 
parcela menor com o envolvimento do pai, além de conflitos relacionados à maternidade (crises após nascimento ou morte de um filho), relações conjugais (divórcio, separação, brigas, tentativas de suicídio, entre outros), diversos tipos de violências sofridas, vida laboral prejudicada e o papel de cuidadoras de outros e da casa.

Tais condições permeadas pela cultura misógina persistem e afetam a dimensão subjetiva das mulheres. Presas a essa condição, elas se julgam incapazes de visualizar qualquer alternativa para amenizar o sofrimento psíquico, de forma que a "implosão" emocional torna-se inevitável. Segundo Garcia (1995, p. 115), "ser mulher em uma sociedade profundamente patriarcal leva a um número desproporcional delas a entrar em colapso". A autora acrescenta que

o distúrbio psíquico configura-se como a exasperação das condições de vida da mulher, pois, na loucura, ela deixa de procurar a razão de seu mal-estar nas suas condições de existência e mostra, através do sofrimento que é a situação de surto, a opressão interior e a perda de qualquer poder sobre si mesma (GARCIA, 1995, p. 119).

No CAPS, esse sofrimento emerge logo no ingresso do usuário/a, ou seja, no momento de acolhimento. É quando as questões da vida privada e pública são explicitadas em temáticas sobre a violência de gênero, opressões, discriminações, papéis sociais, inserção no mercado de trabalho, desigualdades nas relações amorosas, conflitos familiares, dentre outras.

Importante ressaltar, nesta pesquisa, a proporção expressiva de mulheres casadas e separadas em comparação aos homens, isto é, mulheres casadas, em idade madura e adoecidas. Ao que parece, neste estudo, no âmbito da esfera privada, as mulheres vivenciam piores condições relacionadas à conjugalidade. Os problemas enfrentados no casamento, tais como opressão e restrição de espaço, são expressos sob a forma de distúrbios mentais em mulheres, levando-as, muitas vezes, a uma profunda depressão (BASAGLIA, 1987) e a ocupar cada vez mais os espaços psicossociais de saúde.

A interface conjugalidade e sofrimento foi explicitada nos prontuários, por meio das seguintes situações: tentativas de suicídio quando residia com marido ou após o término do casamento; internação, inapetência e choro por acreditar ser traída pelo marido; início das alucinações auditivas após a separação; medo do ex-cônjuge matá-la; desejo de matá-lo; queixa de solidão, abandono e humilhação em relação ao marido; tentativa de matar o cônjuge após descoberta de existência de filha anterior ao casamento; sensação de atrapalhar a vida do companheiro; traição do marido; violência física e psicológica; descoberta sobre a homoafetividade do parceiro; incômodo nas relações sexuais; ideação suicida com o 
casamento e desejo de abandonar os filhos; e envolvimento do marido com a mãe da usuária, com consequente nascimento de uma criança que é irmã da usuária.

Portanto, com base na leitura dos prontuários das mulheres, evidenciamos uma relação entre o casamento e o sofrimento/adoecimento das mulheres, pela queixa frequente relatada pela maioria das participantes - "convivendo e sobrevivendo" em realidades sociais e clínicas bastante semelhantes. Isto permite construir um perfil de mulheres usuárias desse CAPS e suas condições sociodemográficas.

Sobre "religião", encontramos dados sobre essa variável apenas nos registros de um dos psiquiatras, o que sugere certa referência religiosa valorativa do profissional.

Ainda permanecem índices prevalentes de mulheres sem acesso à educação, restritas ao espaço doméstico e, assim, incapazes de promover seu próprio crescimento profissional, condicionadas ao nível educacional baixo, não obstante alguns recentes investimentos governamentais em prol da universalização da educação básica, da erradicação do analfabetismo e do acesso às universidades públicas. Assim, "o acesso à escola reflete circunstâncias sociais e materiais do início da vida, que são reproduzidas de uma geração para outra" (LUDEMIR, 2008, p. 454), ou seja, quanto maiores as perspectivas educacionais, mais mobilidade na vida e inclusão social os indivíduos podem ter.

Um dado significativo diz respeito às donas de casa e ao trabalho doméstico não remunerado, o qual é eminentemente realizado por mulheres no contexto familiar. Segundo Perrot (2013, p. 114), o trabalho doméstico é de responsabilidade feminina e este "caráter doméstico marca todo o trabalho feminino: a mulher é sempre uma dona de casa”. Para essa autora, o trabalho doméstico resiste às evoluções igualitárias e a divisão das tarefas entre homens e mulheres inexiste. Trata-se de um trabalho que, além das características de invisibilidade, fluidez e elasticidade, dependente do corpo, é pouco qualificado e pouco mecanizado, apesar das transformações contemporâneas. Ainda, dados sobre a ocupação, na classificação "outros" abrange ocupações que agregam pouco valor social para ambos os sexos. No que concerne às mulheres, os empregos de menor qualidade a ela reservados foram aqueles que ainda mantêm um caráter doméstico.

Quanto à situação de trabalho, a proporção de homens desempregados superou a de mulheres, dado que pode estar associado à gravidade clínica e incapacitante desses usuários, isto é, os homens com esquizofrenia, transtornos esquizotípicos e delirantes. Dessa forma, 
nesse CAPS, encontramos também maior número de mulheres no mercado de trabalho, em comparação aos homens.

Os dados ainda mostram um percentual alto de mulheres e de homens que não trabalham. Esses dados nos permite inferir que, no geral, estas pessoas encontram-se nas seguintes situações: a espera da aprovação de benefícios sociais/saúde e ou dependência financeira do marido, esposa ou família. Além disso, evidenciamos também maior percentual de homens que exercem atividades informais. O trabalho informal apresenta risco para a saúde mental de jovens (SANTANA et al., 1987). Esse risco relaciona-se a instabilidade, condições ruins de trabalho, baixos salários, jornada excessiva de trabalho, ausência de benefícios sociais e de proteção da legislação trabalhista (LUDEMIR, 2000; 2005).

Em estudo sobre a associação entre desemprego, trabalho informal e transtornos mentais comuns, Ludemir (2000) menciona que o trabalho informal é vivenciado de maneira distinta por homens e mulheres e, especificamente, a associação entre o trabalho informal e os transtornos mentais comuns parece ser presente nas mulheres e ausente nos homens, pois enquanto o trabalho informal significa autonomia e a realização de não ter patrão para os homens, para as mulheres representa uma carga adicional de trabalho, monotonia, oportunidade limitada e não reconhecimento de suas potencialidades. Ou seja, para Ludemir (2000, p. 656), as frágeis relações de trabalho "podem estar negativamente associadas ao bem-estar psicológico feminino". Isso não significa, no entanto, que os homens participantes desta investigação não sofram com a situação de informalidade do trabalho ou desemprego. Embora estudos indiquem as consequências do desemprego para a saúde mental, Ludemir (2008) afirma que ainda não está totalmente compreendido o nexo entre desemprego e transtornos mentais. Entretanto, Shearm et al. (2008) consideram essa condição fator de risco para a saúde mental e afirmam existir alta correlação com transtornos mentais, especialmente quando envolve condição econômica precária da família.

No que concerne à renda familiar, embora os salários mais altos tenham sido observados entre homens, não podemos inferir que haja desigualdade de gênero nesse quesito, pois tal informação não estava presente em grande parte dos prontuários analisados. Sobre os benefícios sociais e de saúde, encontramos que as mulheres recebem mais benefícios que os homens, embora as diferenças não tenham sido significativas pela ausência de dados nos prontuários.

Os resultados sobre ocupação, situação de trabalho, renda familiar e benefícios explicitam a desvalorização social e a precariedade do trabalho na atenção psicossocial 
(SARACENO, 2001), inseridos em um modelo de desenvolvimento social e econômico desigual. Para Martins (2003, p. 13), esse modelo, em suas consequências sociais adversas, "leva simultaneamente a extremos de progresso tecnológico e de bem-estar para setores limitados da sociedade e a extremos de privação, pobreza e marginalização social para outros setores da população". Para atenuar tantos efeitos prejudiciais, Martins (2003) aponta que a alternativa tem sido as políticas sociais compensatórias, necessárias nessa circunstância, apesar de confirmarem e legitimarem a exclusão social, aqui entendida não somente como pobreza, mas problema social procedente da vivência real de experiências dolorosas cotidianas de privações, de limitações e anulações.

As limitações em traçar um perfil por meio de fichas de prontuários existentes não são restritas a um CAPS II do Distrito Federal. Em estudo realizado em serviços de saúde mental no Distrito Federal, Zanello e Silva (2012) evidenciaram a dificuldade de se traçar um perfil sociodemográfico, em virtude da ausência de alguns dados na ficha de admissão e/ou de acolhimento do paciente, tais como renda, trabalho e grupo étnico. Outra pesquisa, com objetivo de identificar características clínicas e sociodemográficas dos usuários do Centro de Atenção Psicossocial (CAPS) do município de Ilhéus, na Bahia, também revelou variáveis não informadas, decorrentes de lacunas e/ou falhas no preenchimento dos prontuários (FREITAS; SOUZA, 2010).

Neste estudo, também emergiram dificuldades para levantamento sociodemográfico, sobretudo decorrentes de letras ilegíveis, dados incompletos e vários campos sem preenchimento (renda familiar, ocupação, benefícios sociais e/ou de saúde recebidos e exame psíquico), o que limitou os achados e o aprofundamento das análises estatísticas. Como mencionado, foi possível detectar, em muitos prontuários, informações divergentes entre ficha de acolhimento e anamnese psiquiátrica, por exemplo, nas variáveis "escolaridade", “ocupação" e "religião". Nesses casos, recorremos à primeira anamnese psiquiátrica, a fim de atualizar a informação sobre o usuário/a. Inexistiram, todavia, informações sobre etnia e raça nos prontuários consultados e, especificamente, em algumas anamneses psiquiátricas foi possível observar a inexistência de dados, como idade, escolaridade, número de filhos, ocupação e religião.

Sobre essa questão, Garcia (1995) aponta que a ênfase nas questões clínicas, relativas à orientação do indivíduo, tem sido priorizada na psiquiatria, em detrimento da vivência do espaço onde se encontra o paciente. Isso não é peculiar à psiquiatria, pois determinadas profissões priorizam suas especificidades, de acordo com a formação profissional. Nesse 
contexto, não podemos isolar e entender as dificuldades desse levantamento sociodemográfico como uma questão local e específica dos profissionais de saúde, sem, contudo, compreender as fragilidades da conjuntura atual das políticas públicas de saúde no Brasil, com características por vezes pouco sensíveis à realidade dos problemas específicos do cotidiano populacional. A integração entre as políticas públicas e as especificidades das políticas de saúde pode ser uma maneira de evitar a armadilha de uma visão simplificada dos problemas sociais e de saúde.

No entanto, essas variáveis mencionadas são relevantes para a análise das condições de vida das pessoas que procuram os serviços de saúde mental. Além disso, evidências indicam que fatores socioculturais contribuem para a compreensão "das diferenças entre os gêneros em saúde e saúde mental” (SHEARM et al., 2008, p. 63), assim como para o entendimento da vulnerabilidade social dos sujeitos com uma maior ou menor inserção no mundo do trabalho e/ou relacional (CASTEL, 1994). Ou seja, faz-se importante a compreensão das "variáveis reais que mudam as vidas reais das pessoas reais", relacionadas aos sujeitos, contextos, serviços e recursos (SARACENO, 2001, p. 83).

\section{CONSIDERAÇÕES FINAIS}

Os resultados apontaram aspectos potencializadores para uma compreensão micropolítica, relacionados ao perfil sociodemográfico de mulheres em comparação aos homens, com características associadas à pobreza, condições de vida precária e exclusão social como dimensões constitutivas do sujeito e seu sofrimento. Isso reforça dados da literatura que associam essas características a fatores de risco à saúde mental.

No entanto, consideramos que a limitação/ausência de dados nas fichas de acolhimento se configurou como um "problema", não da pesquisa em si, mas da inexistência do dado, o que nos leva à compreensão de que a maioria dos profissionais apresentam dificuldades em considerar determinados aspectos da vida do usuário/a significativos para a compreensão do sofrimento psíquico. Persistem ações enviesadas e sujeitos "perdidos" no anonimato, na invisibilidade subjetiva, desprovidos de história individual e coletiva, como menciona Franca Basaglia (1987), o que só reafirma o paradigma biológico em detrimento de práticas sociais e de saúde voltadas ao desenvolvimento de oportunidades e subsídios existentes. As ações, de fato, de educação permanente, atreladas às políticas públicas de saúde 
mental, podem contribuir para qualificar essas práticas, no sentido de construir uma escuta de gênero afinada e sensível ao contexto da atenção psicossocial, como base empírica para futuras intervenções e pesquisas específicas em Centros de Atenção Psicossocial II.

Outra questão que cabe fomentar é a discussão sobre os investimentos em projetos de trabalho e geração de renda e o desenvolvimento de políticas públicas específicas baseadas na interface de gênero e saúde mental. Trata-se de uma forma de garantir o acolhimento das demandas de mulheres e homens, em uma perspectiva de compreensão dos processos sociais integrados ao cotidiano das pessoas em sofrimento.

\section{REFERÊNCIAS}

ALVERGA, Alex R.; DIMENSTEIN, Magda. (2006). A reforma psiquiátrica e os desafios na desinstitucionalização da loucura. Interface, v. 10, n. 20, p. 299-316. Disponível em: $<$ http://www.scielosp.org/scielo.php?pid=S1414-32832006000200003\& script=sci_abstract \&tlng=es>. Acesso em: 10 jun. 2015.

AMARANTE, Paulo. (1995). Novos sujeitos, novos direitos: o debate em torno da reforma psiquiátrica. Cadernos de Saúde Pública, Rio de Janeiro, v. 11, n. 3, p. 491-494. Disponível em: 〈http://www.scielo.br/pdf/csp/v11n3/v11n3a11.pdf〉. Acesso em: 10 jun. 2015.

ARAYA, Ricardo et al. (2003). Education and income: which is more important for mental health?, Journal of Epidemiology Community Health, England, v. 57, n. 7, p. 501-505. Disponível em: <http://dx.doi. org.10.1136/jech.57.7.501>. Acesso em: 10 jun. 2015.

BASAGLIA, Franca. (1987). Mujer, Locura y Sociedad. México: Universidad Autónoma de Puebla.

BRASIL. Ministério do Planejamento, Orçamento e Gestão, Instituto Brasileiro de Geografia e Estatística - IBGE (2014). Síntese de Indicadores Sociais: uma análise das condições de vida da população brasileira. Estudos e Pesquisas Informação Demográfica e Socioeconômica, número 34. Disponível em: <http://cebes.org.br/site/wpcontent/uploads/2014/12/SIS_2014.pdf>. Acesso em: 10 jun. 2015.

BRASIL. Instituto Brasileiro de Geografia e Estatística - IBGE (2009). Sintese de Indicadores Sociais: uma análise das condições de vida da população brasileira 2009. Disponível em: <http://www.ibge.gov.br/home/estatistica/populacao/condicaodevida/indicadoresminimos/sint eseindicsociais2009/>. Acesso em: 10 jun. 2015.

BRASIL. Ministério da Saúde, Secretaria de Atenção à Saúde, Departamento de Ações Programáticas Estratégicas (2004). Saúde mental no SUS: os centros de atenção psicossocial. Disponível em: <http://www.ccs.saude.gov.br/saude_mental/pdf/sm_sus.pdf $>$. Acesso em: 10 jun. 2015. 
CARVALHO, Lúcia de Fátima; DIMENSTEIN, Magda. (2003). A mulher, seu médico e o psicotrópico: redes de interfaces e a produção desubjetividade nos serviços de saúde. Interações, v. 8, n. 15, p. 37-64. Disponível em: <http://pepsic.bvsalud.org/pdf/inter/v8n15/v8n15a03.pdf>. Acesso em: 18 jun. 2015.

CASTEL, Robert. (1994). Da indigência à exclusão, a desfiliação. Precariedade do trabalho e vulnerabilidade relacional. In: LANCETTI, Antônio. (Org.). SaúdeLoucura, n. 4, p. 21-48. São Paulo: Hucitec.

CRESWELL, John W.; CLARK, Vick L. Plano. (2013). Pesquisa de métodos mistos. Porto Alegre: Penso.

DEVERA, Disete; COSTA-ROSA, Abílio da. (2007). Marcos históricos da Reforma Psiquiátrica Brasileira: transformações na legislação, na ideologia e na práxis. Revista de Psicologia da UNESP, v. 6, n. 1. Disponível em:

<http://www2.assis.unesp.br/revpsico/index.php/revista/article/viewFile/46/88>. Acesso em: 18 jun. 2015.

FRANCO, Túlio Batista; BUENO, Wanderley Silva; MERHY, Emerson Elias. (1999). O acolhimento e os processos de trabalho em saúde: Betim, Minas Gerais, Brasil. Cadernos de Saúde Pública, v. 15, p. 345-53. Disponível em:

<http://www.scielo.br/pdf/csp/v15n2/0319.pdf>. Acesso em: 22 jun. 2015.

FREITAS, Aline Araújo; SOUZA, Rozemere Cardoso de. (2010). Caracterização clínica e sociodemográfica dos usuários de um centro de atenção psicossocial (CAPS). Revista Baiana de Saúde Pública, v. 34, n. 3, p. 530-543. Disponível em: <http://files.bvs.br/upload/S/01000233/2010/v34n3/a1882.pdf>. Acesso em: 10 jun. 2015.

GARCIA, Carla Cristina. (1995). Ovelhas na névoa: um estudo sobre as mulheres e a loucura. Rio de Janeiro: Record; Rosa dos Tempos.

GOLDBERG, David; HUXLEY, Peter. (1992). Common mental disorders: a bio-social model. London: Tavistock.

GOMES, Romeu; NASCIMENTO, Elaine Ferreira do; ARAÚJO, Fábio Carvalho de (2007). Por que os homens buscam menos os serviços de saúde do que as mulheres? As explicações de homens com baixa escolaridade e homens com ensino superior. Cadernos de Saúde Pública, v. 23, n. 3, p. 565-574. Disponível em: <http://dx.doi.org/10.1590/S0102311X2007000300015>. Acesso em: 22 jun. 2015.

GROSSI, Miriam; HEILBORN, Maria L.; RIAL, Carmem. (1998). Entrevista com Joan Wallasch Scott. Estudos Feministas, ano 6, n.1, p. 115-124.

LAQUER, Thomas Walter. Inventando o sexo: corpo e gênero dos gregos a Freud. Trad. Vera Whately. Rio de Janeiro: Relume Dumará, 2001.

LAURETIS, Teresa de. (1994) A tecnologia do gênero. In: HOLLANDA, Heloísa Buarque de (Org.). Tendências e impasses: o feminismo como crítica da cultura. Rio de Janeiro: Rocco. p. 206-242.

LUDERMIR, Ana Bernarda. (2008). Desigualdades de classe e gênero e saúde mental nas cidades. Physis, v. 18, n. 3, p. 451-467. Disponível em: <http://www.scielo.br/ 
scielo.php?script=sci_arttext\&pid=S0103-73312008000300005\&lng=en\&nrm=iso $>$. Acesso em: 22 jun. 2015.

LUDERMIR, Ana Bernarda. (2005). Associação dos transtornos mentais comuns com a informalidade das relações de trabalho. Jornal Brasileiro de Psiquiatria, v. 54, n. 2, p. 198204. Disponível em: 〈http://www.saudeetrabalho.com.br/download/informal-ludermir.pdf >. Acesso em: 18 jun. 2015.

LUDERMIR, Ana Bernarda. (2000). Inserção produtiva, gênero e saúde mental. Cadernos de Saúde Pública, v. 16, n. 3, p. 647-659. Disponível em: <http://dx.doi.org/10.1590/S0102311X2000000300013>. Acesso em: 10 jun. 2015.

MARTINS, José de Souza. (2003). A sociedade vista do abismo: novos estudos sobre a exclusão, pobreza e classes sociais. Rio de Janeiro: Vozes.

PERROT, Michelle. (2013). Minha história das mulheres. São Paulo: Contexto.

ROTELLI, Franco ARAYA et al. (1990). Desinstitucionalização, uma outra via. In: NICÁCIO, Fernanda (Org.). Desinstitucionalização. São Paulo: Hucitec. p. 17-59.

SANTANA, Vilma S. et al. (1997). Informal jobs: another occupational hazard for woman's mental health. International Journal of Epidemiology, England, v. 26, n. 6, p. 1236-1242. Disponível em: <http://ije.oxfordjournals.org/content/ 26/6/1236.full.pdf>. Acesso em: 10 jun. 2015.

SANTIAGO, Marina Agra. (2009). Panorama da saúde mental pública no Distrito Federal de 1987 a 2007: um estudo exploratório sobre a reforma psiquiátrica no Distrito Federal. Dissertação (Mestrado em Psicologia) - Instituto de Psicologia, Programa de Pós-Graduação em Psicologia Clínica e Cultura da Universidade de Brasília, Brasília, Distrito Federal, Brasil.

SARACENO, Benedetto. (2001). Libertando identidades: da reabilitação psicossocial a cidadania possível. Belo Horizonte: Te Cora.

SCHMIDT, Moema Belloni; FIGUEIREDTO, Ana Cristina. (2009). Acesso, acolhimento e acompanhamento: três desafios para o cotidiano da clínica em saúde mental. Revista Latinoamericana de Psicopatologia Fundamental, v. 12, n. 1, p. 130-140. Disponível em: <http://www.scielo.br/pdf/rlpf/v12n1/a09v12n1>. Acesso em: 18 jun. 2015.

SCOTT, Joan. (1996). Gênero: uma categoria útil para a análise histórica. Recife: SOS Corpo - Gênero e Cidadania.

SHEARM, K et al. Gênero e fatores socioculturais. (2008). In: REGIER, Darrel A.; NARROW, William E.; FIRST, Michael B.; SIROVATKA, Paul J. Gênero e Idade: considerações no Diagnóstico Psiquiátrico. São Paulo: Roca. p. 124-134.

TELLES FILHO, Paulo Celso Prado et al. (2011). Utilização de benzodiazepínicos por idosos de uma estratégia de saúde da família: implicações para enfermagem. Escola Anna Nery, v. 15, n. 3, p. 581-586. Disponível em:

<http://www.revistaenfermagem.eean.edu.br/detalhe_artigo.asp?id=682>. Acesso em: 22 jun. 2015. 
TENÓRIO, Fernando. (1994). A Reforma Psiquiátrica Brasileira, da década de 1980 aos dias atuais: história e conceitos. História, Ciências, Saúde - Manguinhos, v. 1, n.1, p. 25-59. Disponível em: 〈http://www.scielo.br/pdf/hcsm/v9n1/a03v9n1.pdf〉. Acesso em: 22 jun. 2015.

TRAVASSOS, Cláudia et al. (2002). Utilização dos serviços de saúde no Brasil: gênero, características familiares e condição social. Revista Panamericana de Salud Publica, v. 11, n. 5-6, p. 365-373. Disponível em: 〈http://dx.doi.org/10.1590/S1020-49892002000500011〉. Acesso em: 10 jun. 2015.

VASCONCELOS, Eduardo Mourão (Coord.). (2014). Manual de direitos e deveres dos usuários e familiares em saúde mental e drogas. v. 1. Rio de Janeiro; Brasília: Escola do Serviço Social da Universidade Federal do Rio de Janeiro; Ministério da Saúde, Fundo Nacional de Saúde.

VENTURI, Gustavo; RECAMÁN, Marisol; OLIVEIRA, Suely de. (2004). A mulher brasileira nos espaços público e privado (Orgs). In: RAGO, Margareth. Ser mulher no século XXI ou Carta de Alforria. São Paulo: Editora Fundação Perseu Abramo. p. 31-42.

YASUI, Sílvio. (2007). CAPS: estratégia de produção de cuidado e de bons encontros. In: PINHEIRO, Roseni et al. (Org). Desinstitucionalização da Saúde Mental: contribuições para estudos avaliativos. Rio de Janeiro: CEPESC - IMS/UERJ - ABRASCO.

ZANELLO, Valeska. (no prelo). Saúde mental, gênero e dispositivos. In: Dimenstein, Magda (Org). Condições de vida e saúde mental em assentamentos rurais. São Paulo: Intermeios Cultural, (ano previsto de publicação: 2016).

ZANELLO, Valeska; SILVA, René Marc Costa. (2012). Saúde mental, gênero e violência estrutural. Revista Bioética, v. 20, n. 2, p. 267-279. Disponível em: <http://revistabioetica.cfm.org.br/index.php/revista_bioetica/article/view/745/776>. Acesso em: 10 jun. 2015.

ZANELLO, Valeska; BUKOWITZ, Bruna. (2011). Loucura e cultura: uma escuta das relações de gênero nas falas de pacientes psiquiatrizados. Labrys: estudos feministas, v. 20. Disponível em: <http://www.labrys.net.br/labrys20/brasil/valeska.htm>. Acesso em: 22 fev. 2016. 


\title{
ARTIGO 3 - SAÚdE MENTAL E GÊNERO: O SOFRIMENTO PSÍQUICO E A VIOLÊNCIA CONTRA AS MULHERES
}

\begin{abstract}
RESUMO: As classificações diagnósticas são utilizadas como modelo clínico nas intervenções psiquiátricas no Ocidente. Neste estudo objetivou-se realizar uma leitura sobre os diagnósticos e sintomas, a partir de uma perspectiva de gênero e saúde mental. Estudo transversal, de abordagem quantiqualitativa, com produção de dados por análise de prontuários dos usuários (as). Os resultados demonstram prevalência de diagnósticos relacionados aos transtornos do humor em mulheres, e de esquizofrenia, transtornos esquizotípicos e delirantes nos homens Esses dados, associados ao levantamento do perfil sociodemográfico e à análise dos dados dos prontuários, apontam para a medicalização e psiquiatrização da vida, sobretudo no caso das mulheres, cuja presença em episódios de violência chegou a $32,54 \%$.
\end{abstract}

Palavras-chave: saúde mental; mulheres; violência; diagnósticos; sintomas psíquicos.

ABSTRACT: The diagnosis classifications are used as a clinical model for psychiatric interventions on West. This paper aimed a review about diagnosis and symptoms, from a health mental and gender perspective. It is a cross-sectional study, with a quanti-qualitative method, producing data with the analysis of the patient's records. The results bring up the prevalence of humor disorder in women and, in men, schizophrenia, delirium and schizotypal disorders. Those data, combined to the sociodemographic profile and the analysis of the records, link to the medicalization and the psychiatrization of life, especially for women, whose presence in episodes of violence reached $32.54 \%$.

Keywords: mental health; women; violence; diagnosis; psychological symptoms.

RESUMEN: Las clasificaciones de diagnóstico son utilizadas como modelo clínico de las intervenciones psiquiátricas en Occidente. Este estudio tuvo como objetivo realizar una lectura sobre el diagnóstico y los síntomas, desde una perspectiva de género y la salud mental. Estudio transversal de enfoque cualitativo-cuantitativo, con la producción de datos para el análisis de los registros médicos de los usuarios. Los resultados demostraron una prevalencia de diagnósticos relacionados con los trastornos del estado de ánimo en las mujeres, y en los hombres, la esquizofrenia, trastornos esquizotípicos y delirantes. Estos datos, asociados con el levantamiento del perfil sociodemográfico y el análisis de los registros de datos, apunte a la medicalización y psiquiatrización de la vida, especialmente en el caso de las mujeres, cuya presencia en episodios de violencia alcanzó el 32,54\%.

Palabras-clave: salud mental; mujeres; violencia; diagnóstico; síntomas psíquicos. 


\section{INTRODUÇÃO}

A psiquiatria, na condição de especialidade médica, teve seu início no século XIX, época em que dois grandes paradigmas norteavam sua prática: o clínico-descritivo e o etiológico-anatômico, ambos baseados no tratamento moral das pessoas com doenças mentais (PESSOTI, 1994).

Posteriormente, na primeira metade do século XX, duas correntes de pensamento destacaram-se no cenário psicopatológico, com seus respectivos expoentes: Kraepelin e Freud. Para a primeira, o alicerce das discussões contemporâneas sobre as doenças mentais residia na perspectiva de classificação com base na evolução dos pacientes e no estabelecimento de categorias mutuamente excludentes. Já a segunda fundamentava-se em uma dimensão psicodinâmica da trajetória singular do sujeito, de modo que era necessário compreender em quais circunstâncias, na vida daquela pessoa, havia sido gerado tanto sofrimento (BEZERRA, 2014). Ou seja, enquanto a primeira priorizava o conceito de sintoma como sinal/índice, na segunda ele era concebido como sintoma simbólico. Essas duas bases epistêmicas representaram um divisor de águas da psicopatologia até o fim da II Grande Guerra Mundial (BEZERRA, 2014).

Essa dualidade, no entanto, deixou de existir no pós-guerra, momento em que o campo da psicopatologia foi marcado por distintas concepções e pluralidade de orientações sobre o sofrimento mental. Já vigorava nesse período a Classificação Internacional de Doenças (CID)/OMS, a qual era alvo de críticas por não abordar as síndromes cerebrais crônicas e reações situacionais (BEZERRA, 2014). Em meio a pressões e uma intensa demanda de reivindicação de veteranos (BEZERRA, 2014), a Associação Americana de Psiquiatria criou o Manual Diagnóstico e Estatístico dos Transtornos Mentais (DSM), em 1952, ano da testagem do primeiro psicotrópico - a clorpromazina (RUSSO; VENÂNCIO, 2006). Com o lançamento do Manual, foram criadas as primeiras classificações - o DSM I - sob forte influência psicanalítica e fenomenológica do sofrimento (AGUIAR, 2004; BEZERRA, 2014; DUNKER; NETO, 2011a; RUSSO; VENÂNCIO, 2006). Em 1968, na versão subsequente do DSM, as perspectivas psicanalíticas e fenomenológicas tornaram-se mais evidentes (RUSSO; VENÂNCIO, 2006; BEZERRA, 2008).

No entanto, como estratégia para conferir mais confiabilidade ao diagnóstico e tornálo mais apropriado a fontes de pesquisas, representantes da psiquiatria retiraram as bases epistêmicas da fenomenologia e da psicanálise, especificamente a partir da década de 80, ao 
elaborarem o DSM III, um novo manual para classificação de diagnósticos (AGUIAR, 2004; BEZERRA, 2014; DUNKER; NETO, 2011a).

A criação do DSM III, por sua vez, possibilitou uma importante transformação no campo da psiquiatria e psicopatologia, por representar um sistema de classificação "ateórico" e operacional das grandes síndromes psiquiátricas e, assim, modificar a concepção de pesquisa e da própria intervenção psiquiátrica (DUNKER; NETO, 2011b). Logo, essa perspectiva dita "ateórica" e descritiva vem se constituindo, ao longo das últimas décadas e em contínuo processo de expansão, em um modelo hegemônico da psiquiatria biológica nos EUA, embora sua influência na vida social não esteja restrita ao contexto americano (BEZERRA, 2014; AGUIAR, 2004), o qual se apoia no seguinte tripé: psicofarmacologia, neurociências e genética (IZAGUIRRE, 2011).

Entretanto, cabe perguntar quais as implicações de tal tripé para as sociedades contemporâneas, especialmente no que se refere à vida cotidiana das pessoas e aos serviços de saúde mental que frequentam.

Para Bezerra (2014) e Aguiar (2004), em decorrência da crescente universalização deste modelo classificatório, deslocou-se o foco dos aspectos individuais, singulares a cada pessoa, para transtornos universais, o que trouxe graves consequências, entre elas a explosão dos diagnósticos e expansão do consumo de psicofármacos. Uma vez que os diagnósticos são habitualmente abordados na mídia, tornando-se, portanto, parte de uma cultura diária, sua banalização cumpre a função social de legitimação de uma situação de sofrimento e manuseio dos transtornos mentais (HARPER, 2013). Ainda de acordo com Bezerra (2008), nota-se, inclusive, um vocabulário psicopatológico na vida cotidiana das pessoas.

Assim, o estreitamento da relação entre diagnóstico e tratamento em psiquiatria foi construído em função das relações sociais de mercado, tanto por via da indústria farmacêutica quanto da legitimação da relação médico-paciente descritiva, baseada na avaliação de sintomas para composição dos transtornos mentais, com consequente escolha de determinado psicofármaco (AGUIAR, 2004). Nos últimos anos, vêm sendo adotadas, no Brasil, as versões da Classificação Internacional de Doenças (CID), referência para o Sistema Único de Saúde (SUS). Estas versões, apesar de algumas diferenças em relação à taxonomia dos DSMs, adotam a mesma lógica semiológica e compreensiva daqueles. Importante também pontuar que a psiquiatria não é a única disciplina que se legitima com o diagnóstico, ou seja, a institucionalização do diagnóstico ocorre em outras especialidades médicas, na medida em 
que as organizações, os serviços e planos de saúde são balizados pelos sistemas diagnósticos (HARPER, 2013).

Corroborando essa ideia, Bolton (2009) assinala ter havido um equívoco da psiquiatria ao incorporar a linguagem e os pressupostos da medicina ocidental como forma de encontrar axiomas que abarcassem e justificassem o adoecimento mental, patologizando assim normas sociais e morais para condutas médicas. Em síntese, a função social do diagnóstico psiquiátrico, neste caso, é o de tratar o problema social como questão médica (HARPER, 2013), o que incentiva a prescrição e exacerbação do uso de psicotrópicos.

No que se refere à incorporação dos conceitos médicos, Martins (2003) menciona a complexidade da transposição de uma prática semiológica tradicional da medicina, cuja lógica indicial pressupõe um raciocínio de causa e efeito dos fenômenos, para a compreensão do humano. Para Zanello e Martins (2010), a lógica indicial coaduna-se aos signos motivados, os quais podem ser mais facilmente universalizados, tais como aqueles pertinentes às ciências exatas e biológicas. Diferentemente, no campo das psicopatologias, não há uma implicação de causalidade, um marcador/indicador característico e unívoco que defina o sinal específico da doença (MARTINS, 2003; ZANELLO, 2014a). Já a lógica simbólica proposta por Martins (2003), pertencente ao campo da linguagem, da cultura e produção de sentido para a pessoa, concilia-se com a compreensão do sofrimento psíquico.

Portanto, a adoção de uma semiologia indicial consolidou-se historicamente na psiquiatria e, ao ser importada para o campo da psicopatologia, foi esquecida a especificidade dos tipos de signos e fenômenos (MARTINS, 2003; ZANELLO; MARTINS, 2010). Sob tal perspectiva, a naturalização de fenômenos subjetivos representa um problema de grande amplitude ao desqualificar a fala do sujeito, concebendo a linguagem como mera função, facilmente transformada em sintoma (MARTINS, 2003; ZANELLO, 2014a; ZANELLO; MARTINS, 2010).

A postura de desqualificar a fala do paciente pressupõe considerar a escuta de suas queixas emocionais e corporais meramente como expressão de sintomas. Assim, os diagnósticos psiquiátricos constituem a expressão e materialização de que são, de fato, permeados por julgamentos de valores em sua classificação (FULFORD, 1994; FULFORD et al., 2005).

Embora o DSM se proponha a ser ateórico, suas bases e perspectivas são teóricas, biologizantes, e, portanto, ele não considera a vida do usuário e sua história (SADLER; 
HULGUS, 1994), bem como ignora fatores sociais e culturais inerentes ao sofrimento psíquico dos indivíduos.

Entre esses fatores, invisibilizados nos diagnósticos psiquiátricos, estão as questões de gênero, aqui compreendidas como um termo relacional (entre homens e mulheres), constituídas por contextos políticos, culturais, sociais e econômicos. Segundo Zanello (2014a), se a constituição do sujeito se dá nas relações de gênero, não se pode desconsiderar a importância de valores, estereótipos e ideais na formação do próprio sintoma, ou seja, para essa autora, é extremamente problemática a utilização de critérios diagnósticos neutros que não considerem o gênero e possam invisibilizar o sofrimento de mulheres e homens.

Em pesquisa sobre os principais sintomas e diagnósticos envolvendo dois serviços de saúde mental do Distrito Federal, Zanello e Silva (2012) constataram que grande parte dos diagnósticos femininos apresentava alta correlação entre os Transtornos Mentais Comuns (TMCs) e o processo de medicalização das questões sociais, frente à violência estrutural da população atendida - mulher, negra, semianalfabeta e com profissões subalternas e desqualificadas (donas de casa e/ou trabalhadoras domésticas).

Outro estudo evidenciou o sofrimento psíquico de homens e mulheres em um hospital psiquiátrico. O sofrimento das mulheres concentrava-se mais nas queixas amorosas, relacionais e, para os homens, os valores de gênero convergiram para questões da virilidade sexual e laboral (ZANELLO; BUKOWITZ, 2011). Nesse sentido, cotidianamente, os valores de gênero são evidenciados no campo da saúde mental, especialmente nas experiências vivenciadas por mulheres, as quais envolvem aspectos relacionados ao dispositivo materno (relações de cuidado) e amoroso, mediado pelo ideal de beleza (ZANELLO; GOMES, 2010; ZANELLO; ROMERO, 2012; ZANELLO, 2014a; ZANELLO; FIUZA; COSTA, 2015; ZANELLO, no prelo). Além disso, a violência apresentou uma incidência significativa entre as mulheres que participaram da pesquisa de Zanello e Bukowitz (2011).

Com objetivo de conhecer o itinerário de mulheres em situação de violência de gênero e suas demandas para a saúde mental, Barbosa, Dimenstein e Leite (2014) investigaram a invisibilidade dessas situações, tendo em vista a dificuldade enfrentada pela mulher para ser atendida em tal momento pelos profissionais de saúde. Outro estudo também observou a invisibilidade da violência nesses serviços, ou seja, além de não ser notificada, não é entendida como fator configurador dos próprios transtornos diagnosticados nas mulheres (ZANELLO, 2014b). 
O presente estudo teve como objetivo realizar um levantamento sobre os principais diagnósticos e sintomas de homens e mulheres em um CAPS do Distrito Federal, considerando as invisibilidades dos aspectos de gênero presentes nos prontuários e a presença das diversas formas de violências sofridas por mulheres e homens: física, psicológica, sexual e urbana.

\section{MÉTODO}

Trata-se de estudo transversal, quantiqualitativo (CRESWELL, 2010), baseado em informações dos prontuários de usuários (homens e mulheres) atendidos no Centro de Atenção Psicossocial (CAPS II) em Brasília. Os dados clínicos foram coletados das fichas de acolhimento e da evolução psiquiátrica de todos aqueles admitidos entre os anos de 2012 e 2013, em um total de 234 prontuários (169 mulheres - 72,2\%, e 65 homens - 27,8\%). Os prontuários foram analisados em dois grupos diferentes: de homens e de mulheres.

Constituíram critérios de exclusão: usuários/as que não deram continuidade ao tratamento e cujas fichas de acolhimento e evolução psiquiátrica permaneciam no arquivo permanente do serviço; prontuários que apresentaram apenas a ficha de acolhimento e uma consulta do clínico geral do CAPS (geralmente de usuários/as que ainda passariam por avaliação psiquiátrica); usuários/as que, equivocadamente, se encontravam no arquivo de ativos, porém não apresentavam anamnese psiquiátrica (primeira consulta) ou qualquer evolução psiquiátrica, somente o registro do médico clínico geral desse serviço.

As variáveis analisadas, constantes da ficha de acolhimento, anamnese e evolução psiquiátrica, foram: funções psíquicas alteradas, principais sintomas relatados, diagnósticos principais, diagnósticos indefinidos, e histórico de violências sofridas. Como referência para categorização das funções psiquiátricas alteradas, utilizou-se, segundo recomendação de Dalgalarrondo (2008): consciência, atenção, orientação, vivências do tempo e espaço, sensopercepção, memória, afetividade, pensamento, juízo, linguagem e inteligência, bem como "risco suicídio", "uso de medicação" e "sintomas somáticos", incluindo-se, neste último, somente os registrados na queixa inicial, anotados na ficha de acolhimento. Para construção das frequências correspondentes a cada categoria de função psíquica, foram contabilizados os sintomas, ainda que recorrentes, uma única vez para cada prontuário, 
considerando que um mesmo usuário/a poderia estar inserido em várias destas categorias em virtude da possibilidade de apresentar queixas em distintas classes de sintomas.

Para os diagnósticos conclusivos, as informações foram coletadas da evolução psiquiátrica, categorizando-os segundo a descrição constante da Classificação Estatística Internacional de Doenças e Problemas Relacionados à Saúde/CID-10 (ORGANIZAÇÃO MUNDIAL DA SAÚDE, 1999). Diante do expressivo número de diagnósticos indefinidos, eles foram analisados como um grupo separado: optou-se por considerar casos com dois ou mais diagnósticos registrados (interrogados ou não) nas evoluções psiquiátricas como diagnósticos indefinidos e, nestas situações também, desmembrar homens e mulheres.

Já a variável "violências" foi categorizada de acordo com o seu relato nos prontuários. Utilizaram-se as seguintes categorias de violência: física, sexual, psicológica e urbana. As três primeiras categorias tiveram como parâmetro as definições constantes na Lei Maria da Penha (BRASIL, 2006). Também houve registro de violências sofridas por homens e mulheres e seu (s) diagnóstico (os) correspondente (s), considerando os definidos e indefinidos. Optou-se por enfatizar as violências de gênero contra as mulheres, dada a expressividade de sua presença, e especificidade, nos prontuários femininos, diferentemente da violência urbana encontrada entre homens, além da prevalência de diagnósticos de TMCs dentre elas.

Todas as fichas elegíveis de acolhimento e evoluções psiquiátricas da população foram digitalizadas, utilizando um scanner portátil com base de mesa digitalizadora, e, após, organizadas e identificadas em Ficha de Acolhimento - Ac1, Ac2, Ac3 e Ac4; Anamnese Psiquiátrica - Ap; e evoluções psiquiátricas - consulta 1 até a 22 (número máximo encontrado de registro de consultas psiquiátricas nos prontuários no período). Todas as variáveis mencionadas foram digitadas em um banco de Microsoft Office Excel 2010 para posterior análise.

Utilizou-se análise descritiva por meio de frequências e prevalências absolutas e percentuais relativas a cada grupo, de homens e de mulheres. Como subsídio para a análise qualitativa dos dados, fez-se um levantamento de temáticas recorrentes nos prontuários das mulheres, especialmente nas fichas de acolhimento e evoluções psiquiátricas.

A pesquisa recebeu aprovação do Comitê de Ética em Pesquisa (CEP) do Instituto de Ciências Humanas (ICH) da Universidade de Brasília, por meio do Protocolo $\mathrm{n}^{\circ}$ $692.165 / 2014$. 


\section{RESULTADOS}

De acordo com a planilha geral de dados consolidados pelo CAPS, nos anos de $2012 \mathrm{e}$ 2013 foram inscritas nesse serviço de saúde mental 2.172 pessoas, das quais $1.497(68,9 \%)$ eram mulheres e $676(31,1 \%)$ homens. Tal dado é expressivo quando se observa na demanda (espontânea e ou encaminhamentos dos demais serviços) predomínio de mulheres, fato que suscita algumas questões: Qual é o crivo semiológico utilizado pela equipe para selecionar os pacientes que poderão ter acesso ao tratamento? Esta é uma questão que, embora não tenha sido objeto deste artigo, mostra-se importante para discussão em futuros estudos.

Chamou também atenção o fato de os diagnósticos psiquiátricos registrados terem sido quase que exclusivamente estabelecidos na primeira consulta psiquiátrica (anamnese psiquiátrica). Conforme indicado na tabela 1 , as categorias de diagnósticos psiquiátricos somente estavam definidas para 111 mulheres e 41 homens, o que equivale a um total de 208 diagnósticos elucidados na população deste estudo. Prevaleceram ainda os diagnósticos atribuídos às mulheres, sendo 45,39\% deles de transtornos do humor (transtorno afetivo bipolar, episódios depressivos e transtorno depressivo recorrente) e 20,39\% de transtornos neuróticos relacionados ao estresse e somatoformes (outros transtornos ansiosos, transtornos de adaptação e transtornos dissociativos - de conversão). Já para os homens, o índice de transtornos de humor chegou a 16,07\%; e os de transtornos neuróticos relacionados ao estresse e somatoformes, a 19,64\%. Por outro lado, os dados revelaram alto percentual de homens com diagnóstico de esquizofrenia, transtornos esquizotípicos e delirantes $(39,39 \%)$. Outro relevante resultado evidenciou maior percentual de transtornos de personalidade e de comportamento em mulheres, e de retardo mental em homens. 
Tabela 1- Prevalência dos diagnósticos definidos entre homens e mulheres, de acordo com a CID/10.

\begin{tabular}{lccc}
\hline Agrupamentos diagnósticos & $\begin{array}{c}\text { Feminino } \\
(\mathbf{\%})\end{array}$ & $\begin{array}{c}\text { Masculino } \\
(\mathbf{\%})\end{array}$ & Total (\%) \\
\hline $\begin{array}{l}\text { Transtornos mentais orgânicos, incluindo os } \\
\text { sintomáticos }\end{array}$ & 3,95 & 3,57 & 3,85 \\
$\begin{array}{l}\text { Transtornos mentais e comportamentais } \\
\text { decorrentes do uso de substância } \\
\text { psicoativa }\end{array}$ & 0 & 1,79 & 0,48 \\
$\begin{array}{l}\text { Esquizofrenia, transtornos esquizotípicos e } \\
\text { delirantes }\end{array}$ & 11,18 & 39,29 & 18,75 \\
$\begin{array}{l}\text { Transtornos do humor (afetivos) } \\
\text { Transtornos neuróticos relacionados ao estresse }\end{array}$ & 45,39 & 16,07 & 37,50 \\
$\begin{array}{l}\text { e somatoformes } \\
\begin{array}{l}\text { Síndromes comportamentais associadas com } \\
\text { distúrbios fisiológicos e fatores físicos }\end{array}\end{array}$ & 0,66 & 19,64 & 20,19 \\
$\begin{array}{l}\text { Transtornos de personalidade e de } \\
\text { comportamento em adulto }\end{array}$ & 13,16 & 3,57 & 0,48 \\
$\begin{array}{l}\text { Retardo mental } \\
\text { Epilepsia }\end{array}$ & 3,95 & 12,50 & 6,25 \\
\hline
\end{tabular}

Fonte: elaborado pela autora, segundo dados constantes em prontuários dos usuários do Centro de Atenção Psicossocial II (CAPS II) do Distrito Federal, 2012 e 2013.

Os demais usuários/as que não possuíam diagnósticos definidos totalizaram 82, sendo 24 homens e 58 mulheres. Observou-se variabilidade no número de diagnósticos entre os pacientes, ou seja, alguns não o possuíam e outros tinham mais de um (entre 0 e 7). Notou-se também diferença entre os registros: diagnósticos informados com e sem interrogação e casos em que esses dois tipos de registros constavam em um mesmo prontuário. Adicionalmente, 7 prontuários não possuíam qualquer registro diagnóstico (todos de mulheres), apesar de a medicação ter sido prescrita. Ao que parece, mesmo com a indefinição diagnóstica, a medicação era prescrita e nem sempre a intervenção era realizada por um único médico psiquiatra.

Quanto aos dados sobre os diagnósticos interrogados: naqueles referentes a 48 mulheres havia ponto de interrogação em pelo menos uma das hipóteses diagnósticas. De maneira geral, os mais duvidosos e predominantes em mulheres foram: transtorno afetivo bipolar, seguido de depressão, transtorno de personalidade e esquizofrenia. Já para os homens, 21 deles apresentaram pelo menos um com ponto de interrogação, predominando esquizofrenia e transtornos do humor (transtorno afetivo bipolar e episódios depressivos). De um total de 58 mulheres, 24 receberam 2 diagnósticos associados (interrogados ou não), distribuídos com maior predominância entre transtorno bipolar (15), transtornos de 
personalidade (9) e depressão (8). Ainda, das 58 mulheres, 10 receberam 3 diagnósticos. Ou seja, para as mulheres, houve maior indefinição nesse aspecto; para os homens, 5 possuíam 2 diagnósticos e 9 receberam 3 interrogados.

Quando analisadas as alterações de função psíquica (Tabela 2) que apresentaram maior discrepância entre os sexos, identificou-se que, para as mulheres, a autovaloração, e os sintomas somáticos foram mais expressivos, respectivamente, $51,48 \%$ e 66,27\%. No caso dos homens, a inteligência $(24,62 \%)$, o pensamento $(92,3 \%)$ e o juízo $(58,46 \%)$ mostraram-se mais significativos.

Tabela 2 - Funções psíquicas alteradas entre homens e mulheres

\begin{tabular}{lcccc}
\multicolumn{1}{c}{ Funções psíquicas } & Feminino (\%) & Masculino (\%) & Total (\%) \\
\hline A vontade, psicomotricidade e suas & 91.1 & 89.23 & 90.6 \\
alterações & 98.81 & 98.47 & 98.71 \\
A afetividade e suas alterações & 94.1 & 92.3 & 93.59 \\
Alterações do sono e alimentação & 71.00 & 92.3 & 76.92 \\
O pensamento e suas alterações & 66.27 & 44.62 & 60.26 \\
Sintomas somáticos & 51.48 & 30.77 & 45.73 \\
Alteração da autovaloração & 56.80 & 47.69 & 54.27 \\
A sensopercepção e suas alterações & 44.38 & 38.46 & 42.73 \\
Linguagem e suas alterações & 46.15 & 58.46 & 49.57 \\
O juízo e suas alterações & 38.46 & 33.85 & 37.18 \\
A memória e suas alterações & 14.79 & 15.38 & 14.96 \\
A consciência e suas alterações & 11.83 & 10.77 & 11.54 \\
A atenção e suas alterações & 6.51 & 24.62 & 11.54 \\
A inteligência e suas alterações & 8.28 & 3.08 & 6.84 \\
As vivências do tempo e espaço &
\end{tabular}

Fonte: elaborado pela autora, segundo dados constantes em prontuários dos usuários/as do Centro de Atenção Psicossocial II (CAPS II) do Distrito Federal, 2012 e 2013.

Quando os sintomas foram analisados individualmente, algumas diferenças puderam ser observadas, por exemplo, no que se refere ao choro, que atingiu percentual de $56,21 \%$ em mulheres e 18,46\% nos homens. Outra especificidade observada na esfera afetiva diz respeito à labilidade: 28,99\% em mulheres e 7,69\% em homens. Os sintomas depressivos relacionados a essa função psíquica estiveram presentes em 57,40\% das mulheres e 27,69\% dos homens. A tristeza também foi contabilizada: 59,76\% das mulheres relataram vivenciá-la contra 36,92\% dos homens. Já a sensação de medo atingiu um percentual de 40,83\% entre as mulheres e $30,77 \%$ nos homens, e a de angústia chegou a 37,28\% para mulheres e 24,62\% para homens. A ansiedade para mulheres e homens foi de $69,82 \%$ e $55,38 \%$, respectivamente. 
Para o risco de suicídio (ideação suicida, pensamento suicida e tentativa), registrou-se alto índice para ambos os sexos: $71,02 \%$ entre mulheres e 53,85\% para os homens. Considerando-se as tentativas de suicídio, a maior parte daquelas realizadas por mulheres foi por envenenamento (veneno para rato e outros) e envenenamento por dose excessiva de medicamentos, respectivamente, $41,42 \%$ e $33,14 \%$. Já entre os homens, as tentativas ocorreram por enforcamento $(7,69 \%)$ e envenenamento por medicamentos $(6,15 \%)$. Destacou-se o uso incorreto da medicação, observado em 52,66\% das mulheres e 43,08\% dos homens.

Como temática recorrente nos prontuários, o registro dos tipos de violências entre os sexos apontou: episódios violentos em 55 mulheres, o que totalizou percentual de 32,54\% e, em 12 homens, de 18,46\%. Vinte e duas mulheres tiveram vivência de mais de um tipo de violência e, em geral, houve 26 casos de violências associadas (4 homens), sendo que a proporção de violência registrada no CAPS para homens e mulheres foi de 28,63\%. Nas mulheres, a incidência maior foi de violência física (em 28 mulheres, 35,8\%), seguida de sexual (em 24 mulheres, 30,8\%), psicológica (em 21 mulheres, 27\%) e urbana (em 5 mulheres, 6,4\%). Já entre os homens, predominaram situações de violência urbana (em 7 homens, 46,66\%), seguidas pelas violências psicológica (em 4 homens, 26,67\%), física (em 3 homens, 20\%) e sexual (em 1 homem, 6,67\%).

Como apontamos, em virtude da expressividade dos índices de violências para as mulheres, e de sua especificidade como "violência de gênero", considerou-se oportuno registrar também, no caso delas, os diagnósticos por tipos de violência sofrida, nos 55 casos.

O número de diagnósticos por tipo de violência foi o seguinte: violência física -48 diagnósticos; violência sexual - 42 diagnósticos; violência psicológica - 27 diagnósticos. Quando havia dois ou mais tipos de violência no prontuário da paciente, contabilizou-se cada violência a cada diagnóstico recebido. A depressão foi o diagnóstico predominante nos casos com registro de violência sexual, e os sintomas a ela associados, em geral, foram mais severos: cinco das seis usuárias com episódios depressivos apresentaram um quadro com sintomas psicóticos; além disso, houve mais casos de psicoses (8) neste grupo do que no de outras violências. Identificou-se também maior diagnóstico de transtornos de personalidade (8) e metade deles com a definição clara de "personalidade histriônica". No caso das violências físicas e psicológicas, destacaram-se o espectro da depressão e da ansiedade. No entanto, os transtornos de ansiedade foram prevalentes nos casos de violência física $(31,3 \%)$, e empatados (ansiedade e depressão) nos casos de violência psicológica (25,9\% ambos). 
Também houve diagnóstico de transtorno de personalidade (5), sendo a metade deles definida (“histriônica").

Em relação à análise do/da perpetrador/a da violência, nos casos em que houve violência física, 67,6\% referiam-se a violências recentes cometidas pelo (a) companheiro (a) atual ou ex-cônjuge (87\% das vezes) ou filhos (13\%). As violências físicas sofridas no passado distante da usuária $(32,4 \%)$, em sua infância, referiam-se a pessoas que exerceram a função materna (72,7\%), sobretudo a mãe, mas também a avó, a madrinha e a madrasta. Pai, irmãos e outros familiares também apareceram como perpetradores de violência física $(27,3 \%)$.

$\mathrm{Na}$ violência psicológica, assim como na física, houve predomínio de situações recentes $(70 \%)$, sendo elas cometidas, sobretudo, pelo atual companheiro e ex-marido $(85,7 \%)$ e filhos $(14,3 \%)$. Já a violência psicológica ocorrida no passado das usuárias teve vários representantes familiares (irmãos, padrasto, mãe, etc.), sem destaque de nenhum deles.

Por fim, 73,9\% dos casos de violência sexual ocorreram no passado remoto (infância) da usuária. Os perpetradores foram majoritariamente homens do convívio familiar: tio (35,2\%), "familiares" (sem especificação - 11,8\%), e irmãos (11,8\%). Chama a atenção que em 5 casos não houve registro de quem cometeu a violência. Os outros $26,1 \%$ dos relatos de violência sexual se referiram a um tempo recente ou atual e, neles, apareceram como perpetradores ex-maridos $(83,3 \%)$ e o patrão $(16,7 \%)$.

\section{DISCUSSÃO}

Como apontamos, entre os anos de 2012 e 2013, foram inscritos no CAPS 2.172 pessoas. Tal dado é expressivo quando se observa na demanda (espontânea e ou encaminhamentos dos demais serviços) predomínio de mulheres, fato que suscita algumas questões: Qual é o crivo semiológico utilizado pela equipe para selecionar os pacientes que poderão ter acesso ao tratamento? Esta é uma questão que, embora não tenha sido objeto deste artigo, mostra-se importante para discussão em futuros estudos.

As mulheres apresentaram alta prevalência de diagnósticos conclusivos e, mesmo para aqueles indefinidos, manteve-se o padrão de transtornos do humor em mulheres e esquizofrenia para os homens. Constituíram diagnósticos atribuídos às mulheres nesse 
Serviço: depressão, ansiedade ou a associação entre ambos, apresentando alta correlação com os Transtornos Mentais Comuns (TMCs), cujos sintomas são: insônia, fadiga, irritabilidade, esquecimento, dificuldades de concentração e queixas somáticas. Os TMCs, por sua vez, correlacionam-se a aspectos sociodemográficos e pertinentes a modos de vida, tais como gênero, baixa renda e escolaridade (GOLDBERG; HUXLEY, 1992). Alguns estudos indicam que a frequência de TMCs é maior em mulheres, indivíduos com baixos níveis de escolarização e renda, pessoas de mais idade, entre desempregados e ou envolvidos com o trabalho informal (MARÍN-LEÓN et al., 2007; LUDERMIR; MELO-FILHO 2002; LUDEMIR, 2008; LUDEMIR, 2005). Este estudo foi ao encontro da literatura do tema, pois como levantado e analisado em outro artigo (CAMPOS; RAMALHO; ZANELLO, submetido), a maior parte das mulheres desta população não trabalhava e apresentou baixos níveis escolares e profissões subalternas, como as relacionadas ao trabalho doméstico (CAMPOS; RAMALHO; ZANELLO, submetido).

Além disso, várias temáticas que sinalizam uma invisibilização do sofrimento psíquico das mulheres foram recorrentes nos registros dos prontuários: questões relacionadas à conjugalidade (separações, agressões, traições, conflitos no casamento, descoberta da homoafetividade do marido, desconforto nas relações sexuais, nervosismo após o casamento); à maternidade (tentativa de matar os filhos, rejeitá-los, aborto, óbito fetal, abuso sexual da filha, morte do filho (a), suicídio do filho, entre outras); aos conflitos familiares (abandonada pelos filhos, filho usuário de drogas; perdas familiares - mãe, pai, filhos); e às sobrecargas com os filhos, trabalho e decorrentes da condição de cuidadora de doentes na família.

Todas essas temáticas remetem a um mal-estar das mulheres relacionado a espaços desempoderadores (ZANELLO, no prelo), a uma implosão de sofrimentos de desespero e desamparo, em que "ela deixa de procurar a razão de seu mal-estar nas suas condições de existência e revela, por meio do sofrimento (situação de surto), a opressão interior e a perda de qualquer poder sobre si mesma" (GARCIA, 1995, p. 119). Faz-se mister comentar que o alto índice de risco suicídio, para ambos os sexos, sinaliza um estado intenso de adoecimento e sofrimento.

Sobre a questão diagnóstica, vale comentar que a presença de transtorno de personalidade predominou nas mulheres. Chamou atenção o fato da personalidade histriônica em mulheres ser descrita nas evoluções psiquiátricas por sintomas como: "traços de personalidade histérica", “teatral”, “dramática”, “infantil”, “discurso vitimizado", "lamuriosa", "grande necessidade de receber atenção, afeto superficial, autocomplacência, 
egocentrismo", "chora e manipula". São termos que fazem parte da história da loucura das mulheres e que desqualificam seus sofrimentos. Nesse sentido, a histeria sempre foi considerada uma doença da mulher, como se fosse um estado natural vinculado à essência própria da feminilidade (SHOWALTER, 1995; SHOWALTER, 2004; USSHER, 2013; ENGEL, 2007); inclusive, a histeria tem sido colocada na lixeira da medicina, em virtude da sua natureza nebulosa e multifatorial (USSHER, 2013). Ou seja, há uma tendência a perceber os problemas/sofrimentos apresentados por mulheres como relacionados ao seu modo de ser.

Sobre os sintomas psíquicos apresentados por homens e mulheres, não é possível saber se esses sintomas foram os mais expressivos, apresentados pelo paciente na hora do diagnóstico, ou se o critério subjetivo (gendrado) do psiquiatra privilegiou os achados de forma diferente para homens e mulheres (ZANELLO, 2014a), ou ambas as situações.

De modo geral, a incidência de violências no referido CAPS foi alta. Segundo Schaiber et al. (2005), as violências têm uma repercussão importante na saúde, sendo estas repercussões abordadas no interior dos serviços que, ao mesmo tempo que acolhem os efeitos, tornam sua causa invisível, especialmente aqueles que fazem os diagnósticos, pois terminam por esgotar sua intervenção nesse plano, em que a violência é mascarada por sinais e sintomas. A situação torna-se ainda mais preocupante se considerados os "não registros" dos profissionais, talvez por falta de uma escuta qualitativa das singularidades e particularidades das situações vividas pelos indivíduos.

Destacou-se a incidência da violência sofrida por muitas mulheres atendidas no CAPS neste período. $\mathrm{O}$ ex-companheiro e o atual foram os principais perpetradores de violência física e psicológica no presente ou passado próximo, seguidos pelos filhos, o que coaduna com o último Mapa da Violência produzido no Brasil (WAISELFISZ, 2015), segundo o qual a incidência de atendimentos femininos no contexto da saúde vem crescendo, a maior parte das violências sofridas pelas mulheres ocorre no espaço doméstico e é cometida por familiares ou pessoas do seu convívio. Como menciona Saffioti (2004), "quanto mais familiar, mais desconhecido é o fato, deixando sequer de ser percebido" (p. 45). No que tange ao passado remoto, destacou-se a figura materna na violência física, dado que aponta para a necessidade de investigar, de modo mais aprofundado, o mal-estar da maternidade e suas possíveis interseccionalidades (pobreza, tripla jornada, etc.), não somente nos serviços de saúde mental.

Diante dos dados levantados, faz-se mister perguntar: o que estamos psiquiatrizando? Observa-se que há uma ontologização biomédica dos aspectos sociais e subjetivos dessas mulheres (ZANELLO, 2014a). Ou seja, ao que parece, o diagnóstico tem invisibilizado o 
sofrimento das mulheres em um processo de patologização das questões sociais, em vez de, como aponta Kleinman (1991), considerar o diagnóstico como uma interpretação da experiência da pessoa e, portanto, indissociável das relações sociais e da cultura.

\section{CONSIDERAÇÕES FINAIS}

Os dados levantados neste CAPS apontam para uma psiquiatrização indevida das mulheres. Se os homens apresentam quadros mais graves, tais como psicoses e retardo mental, as mulheres, por seu turno, apresentam quadros de depressão e ansiedade, os quais caracterizam-se como Transtornos Mentais Comuns, altamente correlacionados na literatura tanto com o perfil sociodemográfico dessas mulheres, quanto à situação de violências por elas vividas.

No entanto, os sintomas por elas apresentados são compreendidos de um modo que não estabelece possível relação entre o transtorno, a estrutura socioeconômica, as relações de gênero e o histórico da violência e, portanto, são apenas diagnosticados e medicalizados, visando à sua supressão. Obviamente, essa é uma discussão complexa, no entanto, ao que parece, o CAPS como estratégia potencializadora da Reforma Psiquiátrica em curso no Brasil, permanece em uma lógica medicalizante, sendo que a Política Nacional de Saúde Mental ao invés de assumir o enfrentamento dessa discussão e ampliação dos conceitos, especificamente as violências de gênero dentro dos CAPS, inviabiliza e fragmenta as intervenções, pois claramente temos, de um lado, a pressuposição biomédica e, do outro, ações desinstitucionalizadoras (grupos terapêuticos, geração de trabalho e renda, etc.).

Do exposto, apreende-se que o modelo de atenção psicossocial brasileiro pode não possibilitar um acolhimento adequado às mulheres em geral, se não qualificar as especificidades de gênero e suas interseccionalidades. Isso se aplica ainda mais às mulheres vítimas de violência. Se o grito de sofrimento das mulheres se faz pela implosão psíquica, é necessário buscar outras formas de empoderamento que não as tolham em novo silenciamento como o faz, na maioria das vezes, um tratamento baseado na medicação. 


\section{REFERÊNCIAS}

AGUIAR, Adriano Amaral. (2004). A psiquiatria no divã: entre as ciências da vida e a medicalização da existência. Rio de Janeiro: RelumeDumará.

BARBOSA, Laís. Barreto; DIMENSTEIN, Magda; LEITE, Jáder Ferreira. (2014). Mulheres em situação de violência e seus itinerários em busca de ajuda: um estudo no município de Natal/RN. In: ZANELLO, Valeska; ANDRADE, Ana Paula Muller. Saúde mental e gênero: diálogos, práticas e interdisciplinaridade. Curitiba: Appris.

BEZERRA, Benilton. (2008). Pirando no século XXI: os processos de subjetivação atuais e as novas formas de sofrimento. Vídeo Café Filosófico, CPFL cultura.

BEZERRA, Beniton. (2014). A psiquiatria contemporânea e seus benefícios. In:

ZORZANELLI, Rafaela; BEZERRA, Benilton; COSTA, Jurandir Freire. A criação de diagnósticos na psiquiatria contemporânea. Rio de Janeiro: Garamond.

BOLTON, Derek. (2009). What is mental disorder? Philosophy Psychiatry, v. 8, n. 12, p. 468-470.

BRASIL. (2006). Lei Maria da Penha: Lei n. 11.340, de 7 de agosto de 2006, que dispõe sobre mecanismos para coibir a violência doméstica e familiar contra a mulher. Brasília: Câmara dos Deputados, Edições Câmara. (Série ação parlamentar; n. 422). Disponível em: $<$ http://www2.camara.leg.br/a-camara/secretaria-da.../lei-maria-da-penha/view>. Acesso em: 30 ago. 2015.

CAMPOS, Ioneide de Oliveira; ZANELLO, Valeska; RAMALHO, W. (Submetido). Saúde mental e gênero: o perfil sociodemográfico de pacientes em um Centro de Atenção Psicossocial.

CRESWELL, John W. (2010). Projeto de pesquisa: métodos qualitativo, quantitativo e misto. Porto Alegre: Artmed.

DALGALARRONDO, Paulo. (2008). Psicopatologia e semiologia dos transtornos mentais. 2. ed. Porto Alegre: Artmed.

DUNKER, Christian Ingo Lenz; NETO, Fuad Kyrillos. (2011a). A crítica psicanalítica do DSM-IV - breve história do casamento psicopatológico entre psicanálise e psiquiatria. Revista Latinoamericana de Psicopatologia Fundamental. São Paulo, v. 15, n. 4, p. 611-626.

DUNKER, Christian Ingo Lenz; NETO, Fuad Kyrillos. (2011b). A psicopatologia no limiar entre psicanálise e a psiquiatria: estudo comparativo sobre o DSM. Vínculo, v. 8, n. 2, p. 1-15.

ENGEL, Magali. (2007). Psiquiatria e feminilidade. In: DEL PRIORE, Mary (Org.). História das mulheres no Brasil. São Paulo: Contexto. p. 323-360.

FULFORD, Kenneth W. M. (1994). Closet Logics: Hidden Conceptual Elements in the DSM and ICD Classifications of Mental Disorders. In: SADLER, John Z.; WIGGINS, O. P. Wiggins; SCHWARTZ, M.A. (Eds.). Philosophical Perspectives on Psychiatric Diagnostic Classification, Johns Hopkins University Press. 
FULFORD, Kenneth W. H.; BROOME, Matthew; STANGHELLINI, Giovanni; THORNTON, Tim. (2005). Looking with both eyes open: fact and value in psychiatric diagnosis? World Psychiatry, v. 4, n. 2, p. 78-86.

GARCIA, Carla Cristina. (1995). Ovelhas na névoa: um estudo sobre as mulheres e a loucura. Rio de Janeiro: Record; Rosa dos Tempos.

GOLDBERG, David; HUXLEY, Peter. (1992). Common mental disorders: a bio-social model. London: Tavistock.

HARPER, David. (2013). On the persistence of psychiatric diagnosis: moving beyond a zombie classfication system. Feminism \& Psychology, v. 23 n. 1, p. 78-85.

IZAGUIRRE, Guillermo. (2011). Elogio ao DSM -IV. In: JERUSALINSKI, Alfredo; FENDRIK, Silvia. O livro negro da psicopatologia contemporânea. 2. ed. São Paulo: Via Lettera.

KLEINMAN, Arthur. (1991). Rethinking psychiatry: from cultural category to personal experience. New York: Free Press.

iLUDERMIR, Ana Bernarda; MELO-FILHO, Djalma. (2002). Condições de vida e estrutura ocupacional associadas a transtornos mentais comuns. Revista de Saúde Pública, v. 36, n. 2, p. 213-21.

LUDERMIR, Ana Bernarda. (2005). Associação dos transtornos mentais comuns com a informalidade das relações de trabalho. Jornal Brasileiro de Psiquiatria, v. 54, n. 2, p. 198204. Disponível em: 〈http://www.saudeetrabalho.com.br/download/informal-ludermir.pdf>. Acesso em: 18 jun. 2015.

LUDERMIR, Ana Bernarda. (2008). Desigualdades de classe e gênero e saúde mental nas cidades. Physis, v. 18, n. 3, p. 451-467. Disponível em: <http://www.scielo.br/ scielo.php?script=sci_arttext\&pid=S0103-73312008000300005\&lng=en\&nrm=iso $>$. Acesso em: 22 jun. 2015.

MARÍN-LEÓN, Letícia et al. (2007). Social inequality and common mental disorders. Revista Brasileira de Psiquiatria, v. 29, n. 3, p. 250-253.

MARTINS, Francisco. (2003). Psicopathologia II - Semiologia Clínica. Brasília: Laboratório de Psicopatologia e Psicanálise; ABRAFIPP, 2003.

ORGANIZAÇÃO MUNDIAL DA SAÚDE. (1999). Classificação Estatística Internacional de Doenças e Problemas Relacionados à Saúde - CID-10. 7. ed. São Paulo: Editora da USP, 1999.

PESSOTTI, Isaías. (1994). A loucura e as épocas. Rio de Janeiro: Editora 34.

RUSSO, Jane; VENÂNCIO, Ana Teresa. (2006). Classificando as pessoas e suas perturbações: a "revolução terminológica" do DSM III. Revista Latinoamericana de Psicopatologia Fundamental, São Paulo, v. 9, p. 460-483.

SADLER, John Z.; HULGUS, Yosaf F. (1994). Enriching the psychosocial contente of a multiaxial nosology. In: SADLER, John Z.; OSBORNE, P. Wiggins; SCHWARTZ, Michael 
A. (Eds.). Philosophical perspectives on psychiatric diagnostic classification. London: The Johns Hopikins University Press.

SAFFIOTI, Heleieth. (2004). Gênero e patriarcado: violência contra as mulheres. In: VENTURI, Gustavo; RECAMÁN, Marisol; OLIVEIRA, Suely (orgs). A mulher brasileira nos espaços público e privado. São Paulo: Fundação Perseu Abramo.

SCHRAIBER, Lilia Blima et al. (2005). Violência dói e não é direito: a violência contra a mulher, a saúde e os direitos humanos. São Paulo: Editora Unesp.

SHOWALTER, Elaine. (1995). The female malady: women, madness, an English culture, 1830-1980. London: Penguin Books.

SHOWALTER, Elaine. (2004). Histórias histéricas: a histeria e a mídia moderna. Rio de Janeiro: Rocco.

USSHER, Jane. (2013). Diagnosing difficult women and pathologising femininity: Gender bias in psychiatric nosology. Feminism \& Psychology, v.23, p. 63-69.

USSHER, Jane. (2011). The madness of woman: myth and experience. In: USSHER, Jane (Ed.). Woman and psychology. University of Western Sydney, School of Psychology.

WAISELFISZ, Julio Jacobo. (2015). Mapa da violência 2015: homicídio de mulheres no Brasil. Distrito Federal. Disponível em:

<http://www.mapadaviolencia.org.br/pdf2015/MapaViolencia_2015_mulheres>. Acesso em: 30 out. 2015.

ZANELLO, Valeska. (no prelo). Saúde mental, gênero e dispositivos. In: Dimenstein, Magda (Org). Condições de vida e saúde mental em assentamentos rurais. São Paulo: Intermeios Cultural, (ano previsto de publicação: 2016).

ZANELLO, Valeska; FIUZA, Gabriela; COSTA, Humberto. (2015). Facetas gendradas do sofrimento psíquico. Fractal: Revista de Psicologia, v. 27, n. 3.

ZANELLO, Valeska; ROMERO, Ana Carolina. (2012)."Vagabundo ou vagabunda? Xingamentos e relações de genero". Labrys: estudos feministas, v. 22. Disponível em: <http://www.labrys.net.br/labrys22/libre/valeskapt.htm>. Acesso em: 22 fev. 2016.

ZANELLO, Valeska; SILVA, René Marc Costa. (2012). Saúde mental, gênero e violência estrutural. Revista Bioética, Brasília, v. 20, n. 2, p. 267-279.

ZANELLO, Valeska. (2014a). A saúde mental sob viés de gênero, da semiologia e da interpretação diagnóstica. In: ZANELLO, Valeska; ANDRADE, Ana Paula Müller de. Saúde mental e gênero: diálogos, práticas e interdisciplinaridade. Curitiba: Appris.

ZANELLO, Valeska. (2014b). Saúde mental, mulheres e conjugalidade. In: STEVENS, Cristina; OLIVEIRA, Susane Rodrigues; ZANELLO, Valeska (Org.). Estudos feministas e de gênero: articulações e perspectivas. [livro eletrônico]. Florianópolis: Ed. Mulheres.

ZANELLO, Valeska; BUKOWITZ, Bruna. (2011). Loucura e cultura: uma escuta das relações de gênero nas falas de pacientes psiquiatrizados. Labrys: estudos feministas, v. 20. 
Disponível em: <http://www.labrys.net.br/labrys20/brasil/valeska.htm>. Acesso em: 22 fev. 2016.

ZANELLO, Valeska; GOMES, Tatiana. (2011). Xingamentos masculinos: a falência da virilidade e da produtividade. Caderno Espaço Feminino (UFU), v. 23, n. 1/2, p. 265-280.

ZANELLO, Valeska; MARTINS, Francisco. (2010). O reencontro da clínica com a metáfora. Psicologia em Estudo, Maringá, v. 15, n. 1, p. 189-196. 


\section{ARTIGO 4 - SOFRIMENTO PSÍQUICO E GÊNERO: NARRATIVAS DE MULHERES ATENDIDAS EM UM CENTRO DE ATENÇÃO PSICOSSOCIAL (CAPS II)}

\section{RESUMO}

Este estudo aborda o sofrimento psíquico de cinco usuárias de um Centro de Atenção Psicossocial (CAPS II), sob a perspectiva de gênero. Trata-se de pesquisa qualitativa, baseada em narrativas autobiográficas construídas por meio da técnica da entrevista narrativa. Após levantamento em 169 prontuários do serviço, as participantes foram selecionadas por configurarem casos clínicos considerados "exemplares" da temática em estudo. A análise e a interpretação do material produzido identificaram os núcleos narrativos significativos, reunidos em dois principais temas: 1 . Trabalho como vulnerabilidade atravessada pelo gênero, que originou três subtemas: a) pobreza, infância e trabalho; b) uso e invisibilidade das performances de "mulher"; c) punição por não performar como uma “mulher"; e 2. Relações familiares interpeladas pelas violências sofridas (física, sexual e psicológica), em que aparecem três subtemas: a) relações conjugais; b) maternagem (exercício do cuidado materno); c) relação ascendentes e ou relação com os pais. As narrativas analisadas mostram a vivência de situações dolorosas e estigmatizantes, histórias íntimas de expressão de muito sofrimento e dor psíquica. Face a essas dores, um dos caminhos encontrados por essas mulheres foi a aproximação à religiosidade, aspecto muito importante em suas vidas, visto como alívio e busca de respostas para a dor psíquica. Outra questão presente foi a busca pela emancipação por meio da escolaridade, como forma de "ser alguém na vida". A meta de estudar apareceu aliada a precárias condições de trabalho. O cuidado recebido no CAPS II, embora o foco ainda fosse a doença, emerge como apoio importante a outras formas de ser e se relacionar no mundo.

Palavras-chave: mulheres; sofrimento psíquico; trabalho; família; gênero. 


\begin{abstract}
This study discusses the mental suffering of five users of Center of Psycho-Social Attention (CAPS II), under the perspective of gender. It is a qualitative research, based on autobiographical narratives constructed by means of the technique of the narrative interview. After surveying in 169 medical records of the service, the participants were selected by configuring clinical cases considered "samples" of the theme under study. The analysis and interpretation of the material produced have identified significant narrative cores, gathered in two main themes: 1 . work as a vulnerability crossed by gender, which originated four subthemes: a) poverty, childhood and work; b) use and invisibility of performance of "woman"; c) punishment for not perform as a "woman"; and 2. Family relations challenged by violence suffered (physical, sexual and psychological), in which appear three sub-themes: a) conjugal relations; b) mothering (performance of the maternal care); c) ascendants and relationship with parents. The narratives analyzed show the experience of painful situations and stigmatizing diseases, intimate stories of expression of much suffering and psychic pain. In the face of such pains, one of the paths found by these women was the approximation to religiosity, very important aspect in their lives, seen as a relief and search for answers for the psychic pain. Another issue was the search by emancipation through schooling, as a form of "to be someone in life". The goal to study appeared allied with the precarious conditions of work. The care received in CAPS II, although the focus was still the disease, emerges as important support to other ways of being and relate to the world.
\end{abstract}

Keywords: women; psychic suffering; work; family; gender. 


\section{RESUMEN}

Este estudio analiza el sufrimiento mental de cinco usuarias de un Centro de Atención Psicosocial (CAPS II), bajo la perspectiva de género. Es una investigación cualitativa, basada en narrativas autobiográficas construidas por medio de la técnica de entrevista narrativa. Después del levantamiento en 169 registros médicos del servicio, los participantes fueron seleccionados mediante la configuración de casos clínicos considerados "ejemplares" de la materia de estudio. El análisis e interpretación de los materiales producidos han identificado importantes núcleos narrativos, reunidos en dos temas principales: 1. Trabajo como una vulnerabilidad atravesada por el género, que originó cuatro sub-temas: a) la pobreza, la niñez y el trabajo; b) el uso y la invisibilidad de rendimiento de "mujer"; c) el castigo por no actuar como una "mujer"; y 2. Las relaciones familiares desafiadas por la violencia sufrida (físicos, sexuales y psicológicos), en la que aparecen tres subtemas: a) las relaciones conyugales; b) maternidad (ejercicio de la atención materna); c) ascendente y relación con los padres y madres. Las narrativas analizadas muestran la experiencia de situaciones dolorosas y la estigmatizantes, historias íntimas de expresión de sufrimiento y dolor psíquico. Teniendo en cuenta estos dolores, uno de los caminos encontrados por estas mujeres fue la aproximación a la religiosidad, aspecto muy importante en sus vidas, visto como un alivio y la búsqueda de respuestas para el dolor psíquico. Otra cuestión era la búsqueda de la emancipación a través de la escolarización, como una forma de "ser alguien en la vida". El objetivo del estudio apareció junto con las malas condiciones laborales. La atención recibida en el CAPS II, aunque la enfermedad seguía siendo el foco, surge como un apoyo importante a otras maneras de ser y de relacionarse con el mundo.

Palabras-clave: mujeres; sufrimiento psíquico; trabajo; familia; el género. 


\section{INTRODUÇÃO}

Este estudo aborda o sofrimento psíquico de usuárias de um serviço de saúde mental com base em narrativas autobiográficas de suas experiências, sob a perspectiva de gênero. Para fundamentar a discussão, apropriamo-nos do referencial proposto por Zanello (no prelo), que compreende a saúde mental sob o viés do gênero no campo da psicopatologia, sobretudo em uma leitura gendrada sobre diagnósticos psiquiátricos, com destaque aos valores de gênero implicados no sofrimento psíquico, o qual nas mulheres se configura sobretudo através dos dispositivos amoroso e materno.

A perspectiva de gênero em saúde mental é ainda incipiente no Brasil, notando-se escassas publicações em periódicos científicos nos últimos 10 anos (ZANELLO; RODRIGUES; FIUZA, 2015). Alguns estudos buscam preencher essa lacuna à medida que realizam releituras sobre como homens e mulheres se constroem (ZANELLO; FONSECA; ROMERO, 2011; ZANELLO; SILVA, 2012; ZANELLO; BUKOWITZ, 2011; SANTOS, 2009; ANDRADE, 2010) e como as relações sociais são um vetor que permeia a produção das subjetividades e, consequentemente, as interpretações sobre o adoecimento psíquico (SANTOS, 2009). Entretanto, é necessário um número maior de pesquisas que contemplem a relação gênero e saúde mental (PHILLIPS; FIRST, 2008), especialmente estudos que proponham um contraponto ao caráter histórico e ideológico da loucura como aparato psiquiátrico que seleciona certos "dados", conferindo-lhes um caráter a-histórico e "natural" para o adoecimento (ZANELLO; BUKOWITZ, 2011).

A intervenção psiquiátrica baseada no atual modelo de atenção em saúde fundamentase no paradigma advindo da medicina científica, que estabeleceu o modelo biomédico, o qual, por sua vez, pode desfavorecer a abertura de novas possibilidades existenciais para as mulheres, pois mantém sua centralidade no sintoma, na doença e na crença da neutralidade das técnicas e intervenções (CARVALHO; DIMENSTEIN, 2004). Esse modo de intervenção não contribui para uma escuta (de gênero) qualificada do sofrimento, especialmente das mulheres, uma vez que a análise psiquiátrica é geralmente gendrada e legitimada pela nossa cultura, baseada em uma visão de regulação do comportamento, por meio do controle dos sintomas psíquicos e na construção do sofrimento das mulheres como uma patologia individual. Segundo Carvalho e Dimenstein (2004), 
não se percebe que as queixas recebidas - na maioria das vezes expressas por sintomas físicos ou psíquicos - são decorrentes de problemas econômicos e sociais, de desajustes familiares, dentre outros, e devem ser entendidas de uma maneira mais abrangente. Sem saber lidar com esses problemas, lança-se mão da medicação como único recurso disponível e de fácil acesso (p. 47).

Isso aponta para determinadas situações, já mencionadas por Basaglia (1987), como trabalhar fora do domicílio, cuidar do lar e da família e vivenciar partos de alto risco, que fazem com que as mulheres sofram de forma distinta dos homens. Ocorre o que Garcia (1995) denomina de "implosão", e os sofrimentos psíquicos advindos dessas experiências femininas são, geralmente, medicalizados (CAMPOS; ZANELLO, submetido).

De acordo com Zanello (2014), o sofrimento psíquico é mediado tanto pela linguagem quanto pela cultura e, portanto, para acessá-lo é importante qualificar a fala da pessoa não apenas em seus aspectos objetivos, mas como expressão simbólica e constitutiva. Para essa autora, "o sofrimento psíquico deve ser compreendido em toda a sua complexidade, na qual os aspectos sociais e históricos específicos do sujeito confluem. Entre os aspectos importantes na constituição dos sujeitos, temos as relações de gênero" (p. 44). A noção de gênero compreendida neste estudo é a de categoria relacional, ou seja, considera-se importante estudar mulheres e homens separadamente, o que pressupõe que os valores e papéis de gênero participem da constituição dos sujeitos, não apenas no modo como se expressam, mas também como sofrem, como apontado por Zanello (2014).

Estudos recentes revelam os valores de gênero invisibilizados e psiquiatrizados no contexto da saúde mental. Na pesquisa realizada por Zanello e Bukowitz (2011), as expressões desses valores citadas nas falas de pacientes evidenciam a denominada experiência do "enlouquecer" mediada pelas relações e os papéis de gênero, estabelecidos culturalmente e presentes no cotidiano desses indivíduos. No referido estudo, encontrou-se prevalência de $77 \%$ de queixas relacionais (amorosas, familiares e outras) nos discursos das mulheres, além da busca viril por beleza, sexo e capacidade de cuidado. Para os homens, a prevalência chegou a $71 \%$ de queixas sobre a virilidade sexual, força física, laborativa e dinheiro, além de queixas relacionais, cuja frequência foi baixa nos discursos masculinos em comparação às mulheres. Para as autoras, os discursos de ambos foram marcados por valores de gênero e apontam para diferentes posições subjetivas na experiência do adoecimento, isto é, enquanto as mulheres permanecem vistas como queixosas e ressentidas, os homens constroem um lugar defensivo, presente no discurso viril, o qual se mostrava exacerbado na constituição do delírio. 
Em outros estudos (ZANELLO; GOMES, 2011; ZANELLO; ROMERO, 2012), os valores de gênero também se fizeram presentes, apontando especificidades que dizem respeito às experiências vivenciadas por homens e mulheres. Segundo as pesquisadoras, no que tange às mulheres, a sexualidade é mediada pelo ideal de renúncia sexual, além de um imperativo de cuidado com outro, dedicação a ele, abnegar-se por ele - como traços de caráter relacional. Já o exercício da maternidade aparece como afirmação e naturalização da "essência” feminina.

Esses achados estão em consonância com o pensamento de Basaglia (1987), para quem a participação da mulher na sociedade ocorre nas esferas

corporal e familiar da mulher, que agregam explícitas conotações morais enquanto se referem a sua capacidade ou incapacidade para responder à imagem ideal do que se espera dela: uma boa filha e uma boa mãe, que deve constituir-se, até suas últimas consequências, em objeto sexual, sempre e quando se mantenha dentro dos limites dessa objetivação e sexualização, que correspondem às exigências presumidas da subjetivação masculina, sem deixar transparecer iniciativas ou exigências pessoais que - automaticamente - se converteriam em "obscenas" e condenáveis (p. 32).

Segundo Engel (2007), a psiquiatria contribuiu para legitimar e reforçar essa naturalização do comportamento feminino, uma vez que se encontra inserida num contexto sociocultural e histórico de patologização do adoecimento das mulheres, cuja cultura impõe e é balizada por um padrão de mulher. Desse modo, outro valor imposto diz respeito ao ideal de beleza (mediado pelo dispositivo amoroso), associado fortemente às mulheres (ZANELLO, prelo; ZANELLO; GOMES, 2011; ZANELLO; ROMERO, 2012) como um dever moral e social de ser bela, neste caso, jovem, magra e saudável (NOVAES, 2013). Como consequência, observa-se a busca incessante por alcançar este modelo de beleza mediante aquisição de cosméticos, consumo de medicamentos, dietas alimentares e atividades físicas (SANT'ANNA, 2014). Por outro lado, no que se refere aos homens, os valores relacionam-se à capacidade viril sexual e laborativa (ZANELLO; GOMES, 2011; ZANELLO; ROMERO, 2012). Essas duas vias percorridas por ambos - homens e mulheres - indicam a normatização da função social que propaga uma cultura de atividade sexual intensa, especialmente para os homens, a qual se materializa em termos como "homem pegador", "homem de verdade", mas também pelo aspecto de provedor do lar (ZANELLO; FIUZA; COSTA, 2015).

Em relação ao dispositivo amoroso, Swain (2006) assinala que esse mecanismo de subjetivação investe e constrói corpos em mulher, prontas a se sacrificar, a viver no esquecimento de si por amor a outrem. Além disso, reforça o estereótipo de mulheres dóceis, boas donas de casa, além de conduzi-las para uma heterossexualidade incontornável, 
coercitiva, sem equívocos, uma vez que procriar é considerado prêmio (dispositivo materno). Segundo Zanello (2016), trata-se de um dos principais fatores de desempoderamento das mulheres, que se subjetivam na relação consigo mesmas mediadas pela necessidade de serem escolhidas por um homem para serem validadas enquanto "mulher". Para as mulheres, o amor (ou a forma de amar do dispositivo amoroso) é uma questão identitária (ZANELLO, 2016).

Nessa perspectiva, a pesquisa de Zanello, Fiuza e Costa (2015) destacou aspectos gendrados do sofrimento psíquico, posturas distintas de homens e mulheres diante da situação do sofrimento psíquico grave: "no geral, enquanto elas se queixam que a doença atrapalha o exercício de cuidado dos filhos e do lar (deveres domésticos), eles sofrem pela não produtividade" (p. 240). Nesse estudo, especialmente no discurso feminino, o casamento emerge como dispositivo de manutenção dos papéis tradicionais de gênero e, em $83 \%$ dos casos, o matrimônio foi evidenciado como alternativa para evitar dificuldades financeiras e ou assegurar a moral da mulher, ou ainda, para sair de casa após conflitos com os pais. Os autores elencaram ainda outras temáticas analíticas na fala das mulheres: maternidade; sofrimento decorrente de violências (sexual, física, psicológica); trabalho; invisibilização do sofrimento por ela mesma ou por outras pessoas e sofrimento por não se adequar ao padrão estético.

Levando essas especificidades em conta, o presente estudo teve como objetivo analisar as narrativas de mulheres atendidas em um serviço de saúde mental e suas experiências de sofrimento psíquico, sob a perspectiva de gênero. Para tanto, no primeiro momento, elaboramos o arcabouço teórico por meio de pesquisas já realizadas e, no segundo, examinamos as histórias autobiográficas de cinco mulheres como expressão singular da experiência com o sofrimento.

\section{CONSIDERAÇÕES METODOLÓGICAS}

Tratou-se de estudo exploratório, com abordagem qualitativa (DENZIN; LINCOLN, 2006; FLICK, 2009; MINAYO, 2004) e utilização de técnica para produção de dados por meio de entrevistas narrativas $(\mathrm{EN})$ de mulheres atendidas em um Centro de Atenção Psicossocial II de Brasília. 
A priori, realizamos a leitura de 169 prontuários de mulheres atendidas no período 2012 a 2013. Observamos, nesse processo inicial, convergências de determinados temas relacionados à pobreza e trabalho, às violências de gênero, ao sofrimento na conjugalidade heterossexual, além do exercício da relação materna, tal como mencionado em duas de nossas publicações em coautoria (CAMPOS; ZANELLO; RAMALHO, submetido; CAMPOS; ZANELLO, submetido).

O levantamento dos diagnósticos atribuídos a essas mulheres que frequentaram o serviço no mencionado período revela que $71 \%$ receberam diagnósticos conclusivos, com prevalência de: depressão (28\%), transtorno afetivo bipolar (17\%), transtornos de ansiedade (13\%) e transtorno de personalidade (13\%). Os temas mais recorrentes encontrados nos prontuários analisados foram: episódios de violência doméstica em 55 mulheres $(32,54 \%)$; sofrimento e conjugalidade ( $21 \%)$; e, por último, $14 \%$ das queixas referiram dificuldades no exercício da maternidade. Com base nesse levantamento, definimos como critério de seleção os casos clínicos "exemplares", por mostrarem claramente a recorrência dos temas citados acima.

Inicialmente, 05 mulheres avaliadas como "exemplares" dos sofrimentos retratados e recorrentes nos prontuários foram selecionadas. Além disso, foram escolhidas mais 07, como reserva, caso houvesse transferência para outro ponto da RAPS (Rede de Atenção Psicossocial), chance de abandonarem o tratamento ou uma das cinco primeiras não aceitarem participar da pesquisa. Do total das 12 mulheres inicialmente selecionadas, entrevistamos 07, sendo que 02 foram excluídas do estudo devido à dificuldade, no momento da entrevista, do exercício mínimo de si mesma e da comunicação. Ao final, selecionamos cinco (05) casos, sendo dois (02) com diagnóstico de depressão, um (01) de transtorno afetivo bipolar, um (01) com transtorno misto (ansiedade e depressão) e uma mulher (01) diagnosticada com transtorno de personalidade.

Como técnica para produção das informações, utilizamos o método da EN inspirado em Schutze, como proposto por Jovchelovitch e Bauer (2002), o que facilitou a nossa abordagem às mulheres com experiências de sofrimento. Para esses autores, a entrevista encoraja e estimula o entrevistado a discorrer sobre a sua trajetória ou mesmo algum acontecimento importante de sua vida (JOVCHELOVITCH; BAUER, 2002). Esse tipo de entrevista permite, sobretudo, que o entrevistado assuma um papel ativo (ROSENTHAL, 2014) na sua história. Para Brandão e Germando (2009), "a principal ideia é que se possa gerar uma história que não seja estruturada por questões propostas pelo entrevistador, mas 
pelo fato que o narrador julgou relevante contar ao seu interlocutor" (p. 8). Assim, justificamos que a escolha por esse método decorre do potencial que as EN têm de gerar histórias e reconstruir acontecimentos da vida.

De acordo com Jovchelovitch e Bauer (2002), a entrevista narrativa se processa em 4 fases: 1) o entrevistador menciona a questão central para o entrevistado; 2) o entrevistado inicia sua narração, devendo evitar interrupções que possam direcionar o seu processo de criação do enredo, de modo que as questões imanentes (temas, tópicos e relatos de acontecimentos) surjam na narração trazida pelo informante 3) fase dos questionamentos, na qual o entrevistador pode obter determinados esclarecimentos (fragmentos da narrativa que não ficaram claros para o entrevistador) após finalização da fala do entrevistado; as questões exmanentes (que refletem o interesse do pesquisador) são expostas pelo entrevistador ao entrevistado e; 4) fala conclusiva, momento em que é permitido interromper a gravação e anotar alguns comentários informais trazidos pelo narrador.

O contato entre entrevistadas e entrevistadora foi mediado pela equipe técnica. Um roteiro foi elaborado contendo cinco questões abertas, norteadoras, com potencial de serem disparadoras da EN: Conte um pouco sobre a sua vida; Desde quando frequenta o CAPS?; Já frequentou outros serviços de saúde mental?; O que aconteceu na época?; Fale sobre os seus projetos de vida.

As entrevistas (EN) tiveram duração variável, entre 2 a 4 horas cada e, após a leitura do material contendo cerca de 80 páginas impressas, foi necessário um novo encontro individual com duas mulheres para esclarecimento de algumas dúvidas sobre as histórias por elas narradas. Todas as entrevistas foram gravadas e transcritas, após a assinatura do Termo de Consentimento Livre e Esclarecido (TCLE). Dados que pudessem identificar a instituição e os participantes foram devidamente retirados dos resultados, tendo sido adotados nomes fictícios e identificadas as entrevistas como entrevista narrativa - (EN1-Maria), (EN2-Joana), (EN3-Larissa), (EN4-Rosa) e (EN5-Marina). A pesquisa recebeu aprovação do Comitê de Ética em Pesquisa (CEP) do Instituto de Ciências Humanas (ICH) da Universidade de Brasília, por meio do Protocolo n ${ }^{\circ}$ 692.165/2014.

Para a análise e interpretação das narrativas, adotamos os seguintes procedimentos: leitura simples e minuciosa de cada entrevista; sinopse de cada caso com identificação da sequência dos eventos/acontecimentos da vida das mulheres, para a construção individual dos enredos das usuárias, incluindo o recorte dos fragmentos das falas; e categorização dos núcleos significativos das narrativas. 
Posteriormente, na análise conjunta das entrevistas, emergiram duas grandes categorias dos núcleos significativos narrativos como fatores que contribuíram para a dor psíquica dessas mulheres ao longo de suas trajetórias: 1. Trabalho como vulnerabilidade atravessada pelo gênero, com diferentes configurações a depender da fase da vida; 2 . Relações familiares interpeladas pela violência.

A primeira categoria apresentou quatro subtemas: a) Pobreza, infância e trabalho, ou seja, o trabalho como expropriação do "cuidado", mesmo que de uma menina, como forma de sobrevivência e acesso à educação (subtema presente nas narrativas de duas usuárias); b) Uso e invisibilidade das performances de "mulher", expropriando o trabalho doméstico, como também de seu corpo (subtema presente na narrativa de uma usuária); c) Punição por não performar como uma "mulher", no trabalho (subtema presente nos relatos de duas usuárias).

Já na segunda categoria, destacaram-se três subtemas: a) relações conjugais; b) maternagem (exercício do cuidado materno); c) ascendentes e/ou relação com os pais; sendo as violências física, psicológica e sexual aspecto que permeia essas relações.

Com base na elaboração das narrativas autobiográficas, apresentamos a história de cada uma das mulheres entrevistadas.

\section{APRESENTANDO AS MULHERES E SUAS HISTÓRIAS DE VIDA}

Maria, a primeira entrevistada, tem 49 anos; é negra, casada e dona de casa, não tem filhos, nascida no Nordeste, estudou até o ensino fundamental e frequenta a igreja evangélica. Trabalhou como empregada doméstica ao longo de sua vida e atualmente não exerce atividade remunerada, estando dependente do atual marido, o qual é aposentado e faz "bicos" de jardinagem. Narra sua vida sofrida e pobre: trabalho precoce como babá e doméstica, pelo qual recebia apenas o material escolar como remuneração financeira. Sofreu violência sexual seguida de aborto forçado na adolescência, assim como agressões físicas do primeiro marido, que, em um dos episódios, resultaram no aborto de gêmeos. Segundo a mesma, ele inclusive a estuprava durante o casamento. Com a separação, Maria retomou o trabalho como empregada doméstica e também como garota de programa, no entanto, sofre com a rejeição e o preconceito familiar. Passou também a frequentar a igreja, abandonou a prostituição e casouse novamente, com um homem bom e provedor, mas se sente frustrada por não ter sido mãe e 
pela impotência sexual do atual marido. Encaminhada do hospital psiquiátrico para o CAPS no ano de 2013, atualmente possui o diagnóstico de transtorno de personalidade histriônica.

A segunda entrevistada foi Larissa, 34 anos, que procurou o CAPS espontaneamente em 2012 e tem diagnóstico de depressão. Natural da Região Sudeste, é solteira, sem filhos, ensino superior incompleto, operadora de telemarketing, atualmente afastada do trabalho e frequentadora da igreja evangélica. Sua infância e adolescência foram marcadas pela violência física do pai e abuso sexual pelo tio, sendo este último silenciado durante anos por medo de eventual acontecimento drástico na família. Por sofrer bullying na escola, não queria mais frequentá-la, embora o pai a obrigasse. Não mantém boa convivência com os irmãos. Tentou suicídio várias vezes em virtude de frustração em um relacionamento amoroso e término do noivado, pois descobriu que o namorado era casado, e, além de tudo, a extorquia, motivo pelo qual adquiriu diversas dívidas por ele contraídas, abandonou o curso de graduação e ganhou peso. Narra o início do trabalho como operadora de telemarketing e o assédio sexual por parte de um dos colegas da empresa. Afastou-se do trabalho para tratamento da depressão e possível cirurgia bariátrica.

Joana foi a terceira entrevistada. Uma mulher de 63 anos, natural da Região CentroOeste, dona de casa, católica, viúva, três filhos, ensino médio completo, artesã aposentada. Foi diagnosticada com depressão e acolhida no CAPS em 2013, encaminhada do hospital geral. Narra uma história de vida marcada pelo sofrimento. Casou-se para se libertar do pai, o que, para ela, foi a "mesma coisa de sair do espeto e cair na brasa", pois o marido a cerceava de trabalhar e visitar seus familiares. A convivência com o companheiro que a via como objeto doméstico e sexual era entendida como expressão de carinho e amor. Após três anos de casamento, ele matou o irmão de Joana durante uma briga e manteve-se foragido até retornar para sequestrá-la. Ela, então, viveu com ele uma vida nômade durante 20 anos. Enfrentaram (ela e os filhos) dificuldades financeiras e fome, além da coação para sempre omitir o seu paradeiro; trabalhou como professora de pintura para suprir as demandas da casa, sendo que boa parte do dinheiro de seu trabalho como artesã era entregue ao marido, enquanto o mesmo vivia na boemia, na poligamia e nos negócios financeiros escusos.

Além das violências física e psicológica, sofreu estupro no casamento, contraiu doença sexualmente transmissível, que evoluiu para um câncer de útero, retirado posteriormente. Joana ainda tentou o suicídio diversas vezes, mas, por não ter coragem de deixar os filhos, decidiu fugir para a casa dos pais. $\mathrm{O}$ marido, no entanto, manteve as ameaças, mas não retomou o ciclo de violências. Foi cuidadora da mãe antes de sua morte, retomou os estudos e 
iniciou o tratamento da depressão, pois os irmãos notaram que estava em um profundo processo de emagrecimento.

A quarta entrevistada foi Rosa, 28 anos, nordestina, diagnosticada com transtorno misto (ansiedade e depressão) e acolhida no CAPS no ano de 2013, encaminhada do hospital psiquiátrico. É casada, tem uma filha, ensino médio incompleto, espírita e trabalha como vendedora. Foi abandonada pela mãe quando tinha um ano de idade na casa da avó materna, onde sofreu maus tratos (violência física e psicológica) e racismo durante a infância e adolescência. Trabalhava como empregada doméstica da avó, mas mantinha o objetivo de estudar. Devido à violência perpetrada pela avó e pelo tio, mudou-se para a casa de uma tia, onde novamente trabalhou como doméstica, em troca de continuar estudando. Rosa conseguiu morar sozinha após obter emprego, iniciou namoro e engravidou. Por não desejar a criança, chegou a concordar em fazer o aborto sugerido tanto pela sogra quanto pelo namorado, mas desistiu e foi morar na casa da sogra. Sonhava em se casar, mas vivenciou uma gravidez solitária e a poligamia do namorado. Com o nascimento da filha, Rosa mudou-se para um "barraco", e seu marido recusava-se a trabalhar e cuidar da criança, o que fez com que ela tivesse que assumir simultaneamente os afazeres domésticos, os cuidados com a criança e o trabalho como vendedora de sapatos. Sobrecarregada, passou a vivenciar crises de ansiedade no trabalho, inclusive com sentimento de rejeição à filha e sintomas evasivos de agressão a ela.

Marina, última entrevistada, tem 46 anos. Encaminhada pelo hospital psiquiátrico, foi acolhida no CAPS em 2013 e diagnosticada com transtorno bipolar. É natural da Região Centro-Oeste, evangélica, casada (segundo casamento), três filhas, ensino superior incompleto, e atualmente afastada do trabalho. Sofreu violência física e sexual (estupro) no primeiro casamento, seu ex-marido não trabalhava e ainda contraía dívidas em seu nome. Marina foi dedicada e bem sucedida nas empresas onde trabalhou, e a gravidez indesejada das filhas gêmeas a deprimiu. Na época, sentia dependência afetiva da mãe (seu suporte) e desamor pelas filhas. Casou-se novamente e a não aceitação do segundo marido trouxe conflitos familiares e a mudança das filhas para a casa da mãe. Engravidou novamente e, mais uma vez, se deprimiu. Trabalhou em duas empresas que a advertiram por seu comportamento (humor oscilante), sendo que uma delas a demitiu e a outra recomendou tratamento psicológico e psiquiátrico. Marina iniciou sua trajetória como paciente psiquiátrica, passou por internações em hospital psiquiátrico público e clínica particular, tentou suicídio e apresenta várias marcas pelo corpo devido a automutilações. Após a morte da mãe, seus 
sintomas intensificaram-se e relata dificuldades em impor limites ao comportamento das filhas adolescentes. Sente-se sobrecarregada.

\section{AS DIMENSÕES SUBJETIVAS DO SOFRIMENTO PSÍQUICO - HISTÓRIAS E EXPERIÊNCIAS DE MULHERES "LOUCAS"}

"Minha vida é sofrimento que vou te falar uma coisa, pode ter sofrimento igual eu tenho, eu 'num' sou a única”. (EN2)

Após análise das narrativas dessas cinco mulheres, destacamos duas principais categorias dos núcleos narrativos como fatores que contribuíram para a dor psíquica ao longo de suas trajetórias: a primeira, o trabalho como vulnerabilidade atravessada pelo gênero (com diferentes configurações a depender da fase da vida); a segunda, relações familiares interpeladas pelas violências. São categorias marcadas, sobretudo, pela invisibilidade, no sentido de que é um trabalho que, uma vez não reconhecido ou explorado e expropriado, configura fator de vulnerabilidade. Além disso, as relações familiares, em virtude da forma como ocorrem na conjugalidade, são marcadas também pela expropriação do próprio corpo, pela violência e a maternagem, por um papel que elas não conseguem exercer plenamente ou pela sobrecarga.

\section{Trabalho como vulnerabilidade atravessada pelo gênero}

Nesta primeira categoria, apresentamos três subtemas que discutiremos a seguir. $\mathrm{O}$ primeiro deles, a) Pobreza, infância e trabalho, refere-se ao trabalho como expropriação do "cuidado", ainda que de uma menina, como forma de sobrevivência e acesso à educação, tal como na história de Maria. No caso dela, para atenuar as condições precárias em que vivia, precisou trabalhar como babá doméstica na adolescência, em uma relação marcada pela exploração do trabalho de uma criança que cuida de outra, sem remuneração financeira, somente em troca do material escolar. Maria também sofreu abuso sexual pelo filho da patroa, o que já a coloca em situação de extrema vulnerabilidade, visto que precisou morar com uma família que não era a sua, deixando sua casa, seu ponto de apoio, para ser apropriada e 
explorada em seu corpo. Nesse sentido, Maria sofreu duplamente: pela violência sexual e por silenciá-la, ou seja, para ter acesso à educação, ela se submeteu a mercantilizar o cuidado; mesmo sendo uma criança que precisava ser amada e cuidada. Ao final, no entanto, não alcançou o seu objetivo maior de estudar, pois concluiu somente o ensino fundamental.

Para Arend (2013), em muitas famílias pobres, as filhas não precisavam estudar, pois se pressupunha que as meninas, desde muito cedo e sem escolaridade formal, já tinham conhecimento suficiente para ajudar os pais na manutenção da família e, após, sobreviver na vida adulta. Para essa autora, entre as mulheres pobres, rurais e urbanas, além dos processos relativos ao corpo (a menstruação e a gravidez), o que demarcava o ingresso na mocidade era o fato de a menina estar apta para trabalhar, especialmente fora de casa, na maioria das vezes entre 10 e 13 anos. Foi justamente este o caso de Maria, que aos 13 anos foi trabalhar em casa de "família", com todo apoio de seus pais.

$\mathrm{O}$ acesso ao trabalho marcado pela domesticidade e expropriação do próprio corpo esteve presente tanto na narrativa de Maria quanto na de Rosa. O trabalho infantil, na história de Rosa, apareceu fortemente marcado por dor e mágoas, no sentido de que pagou para estudar, sendo doméstica da avó, sem receber remuneração individual. Teve uma trajetória social traçada pela opressão e exploração da avó, e sua infância de brincadeiras foi roubada. Para sobreviver, mesmo não recebendo um salário, precisou trabalhar como se fosse uma funcionária doméstica e conseguiu concluir apenas o ensino médio. Isso mostra a inserção precoce do trabalho doméstico na vida de mulheres pobres como recurso de sobrevivência; evidencia ainda a lacuna e/ou ausência de políticas públicas e o não cumprimento do Estatuto da Criança e do Adolescente, criado em 1990 pelo Estado brasileiro, quando Rosa tinha 5 anos. As narrativas de Maria e Rosa revelam algumas das muitas dificuldades por elas vivenciadas:

"eu fui pra cidade, morar numa casa de família pra isso, já começar a ser babá aos treze anos e ganhando o material escolar e o uniforme pra continuar os meus estudos". (EN1-Maria)

"abusava de mim, eu tinha acabado de ficar mocinha, [...] foi abusando [...] e fazendo ameaças se eu abrisse a boca e eu fui começando a travar, a ficar medrosa de ir pra escola, mas eu não tinha outra saída e nem podia contar pras pessoas [...] saí da casa dos meus pais muito cedo e... sempre querendo vencer na vida, ser alguém na vida, estudar, conseguir um lugar ao sol e houve esse fato que interrompeu... De certa forma podou os meus sonhos, limitou os meus sonhos, mas eu continuei!’. (EN1Maria) 
"a gente vivia pra arrumar as coisas pra ela, arrumar casa, cuidar de roça, cuidar de gado. E meu tio também era aquela coisa assim, a gente tinha que prontar água pra ele tomar banho como se fosse um bebê... E isso tudo eu tinha o quê? Seis, sete, oito anos". (EN4-Rosa)

As narrativas acima mostram, sobretudo, a exploração pelo corpo, pela sexualidade e pelo trabalho durante a infância. Já nas outras três narrativas, a ênfase no trabalho emerge na vida adulta. A primeira delas, presente no subtema b) Uso e invisibilidade das performances de "mulher", expropriação do trabalho doméstico e também de seu corpo, esteve fortemente presente na história de Joana, que empenhou todos os seus esforços no ambiente doméstico, ou seja, viveu para a família, o marido, os filhos e cuidados com a casa - um trabalho invisível e não remunerado (PERROT, 2013). A condição de "mulher", dona de casa perfeita, foi incorporada por Joana, pois todo o trabalho doméstico era de sua responsabilidade, que além de não ser remunerada para tanto, não tinha o reconhecimento do marido. Para Perrot (2013), essa condição de “'mulher' é um peso na sua identidade: a dona de casa perfeita é o modelo idealizado de boa educação, e torna-se um objeto de desejo para os homens e uma obsessão para as mulheres" (p. 114).

Outra questão importante na vida de Joana refere-se ao seu acesso ao dinheiro. Ela fazia "bicos" como artesã e quando conquistou o pouco que necessitava para ter sua independência em relação ao marido, foi punida por isso, sendo arrastada de casa até o banco pelo marido, para que retirasse todo o seu dinheiro. Fica claro, portanto, que não obstante ser responsável pelo trabalho doméstico, a possibilidade de sujeitá-la por meio da força física, psicológica ou econômica reafirmou o poder por ele exercido sobre ela (BASAGLIA, 1987), em uma relação mulher-subordinação-objeto.

Diferentemente de Maria e Rosa, Joana conseguiu concluir o ensino médio porque morou com os pais; e como eles possuíam uma boa condição socioeconômica, contratavam uma professora para lhe dar aulas na fazenda onde moravam. Nesse sentido, ela obteve apoio para estudar, inclusive tornou-se professora na própria fazenda onde viveu. No entanto, o início da vida com o marido após a mudança da casa dos pais, momento por ela descrito como sair do "espeto para cair na brasa", trouxe um sofrimento duplo.

Se ao lado dos genitores, ela usufruía do conforto de uma "boa moça" e não exercia as tarefas domésticas na roça, o casamento impôs significativas dores e sobrecarga doméstica, pois, além de se esforçar para parecer a "esposa perfeita" para a sogra, Joana se colocava a seu serviço, quando esporadicamente a encontrava. Ao que parece, o silêncio, a servidão e a 
sobrecarga de Joana eram entendidos pela sogra como aspectos naturais da condição da "mulher". Os trechos abaixo expressam o sofrimento vivenciado:

"esganchada em cima dum cavalo, apartando vaca, buscando bezerro no meio do mato, campeano vaca, vaca parida! Cascano milho pra porco, criano frango, criano galinha" [...]. (EN2-Joana)

"Morava na roça, ele ia tomar banho, era banho de bacia mas o chinelinho "tava" ali, a toalha tava ali, tudo limpinho! Cama limpinha e cherosa. Eu vivi os anos de casada pra ele, minha vida parou ali”. (EN2-Joana)

"Então ela chegava na minha casa e ficava lá uma semana, essa semana era só felicidade. Era só eu matando frango, fazendo 'pãozim' de queijo pra ela, fazendo coisa pra agradar". (EN2-Joana)

No fragmento abaixo, ela comenta a fala de um dos filhos:

'Mãe, a senhora 'tá' achando que 'os escravo' acabou? Ainda existe escrava e branca, que a senhora é escrava do meu pai. Isso meu filho nunca tinha falado e falou na frente do meu marido. Aí meu marido: 'Cala a boca que eu parto... que eu viro seus... que eu quebro seus dentes"'. (EN2-Joana)

O último subtema da categoria trabalho atravessado pelo gênero, c) Punição por não performar como uma "mulher" no trabalho, foi observado nas narrativas de duas mulheres. Marina é a primeira delas, uma mulher bem sucedida, líder e competente, demitida após atuar por muitos anos no sistema de automação bancária. No segundo emprego, trabalhava com ativação e implantação do circuito de dados e voz de uma grande empresa de telecomunicação, da qual está afastada atualmente.

"Eu tinha o emprego dos sonhos, ganhava bem pra caramba e simplesmente tirei férias e fui demitida porque eu não estava dentro do perfil da empresa [...], com essa empresa de hoje foram falar da mesma coisa, [...] Num é do meu trabalho, não é o que eu faço em si, é do meu comportamento. [...] Porque com a demissão do trabalho eu fiquei desnorteada, eu fiquei angustiada, eu tentei um suicídio [...], só vinha a vontade de morrer, chega essa vontade, quando eu falava assim que eu tinha vontade de morrer, chega me dava ânsia de vômito!’. (EN5- Marina)

Marina referiu não compartilhar com os colegas suas estratégias de trabalho, o que não significa que ela ocultava os resultados, mas que temia ser explorada, receava nova apropriação e perda do reconhecimento. Apesar de não ter sequer iniciado curso superior, ela se dedica e é extremamente competente, mas apresenta postura de resistência à exploração, sendo orientada pela empresa a buscar auxílio psicológico e ou psiquiátrico. Ao que parece, a 
falta de comunicação e eventual inadequação ao perfil da empresa baniram as suas oportunidades de trabalho, e ela passou de líder a louca, problemática e egoísta. O não performar como uma "mulher" no ambiente profissional apareceu também na narrativa de Larissa, que sofreu assédio sexual no trabalho e já havia sido assediada pelo tio na infância e adolescência. Vivenciar novamente essa agressão levou-a a uma importante ruptura psíquica e, como consequência, passou a apresentar ataques de pânico.

No entanto, esses ataques, em vez de serem compartilhados e acolhidos, foram silenciados no trabalho em diversos momentos, por exemplo, quando a chefe recusou o atestado de Larissa, alegando ser necessário cumprir as metas. À época, determinou ainda que ela continuasse produzindo, aceitasse e seguisse as regras; no entanto, após um comportamento de desobediência, Larissa foi punida. Ela não é vista como louca, mas não é promovida e sente-se excluída. Apesar de conseguir ingressar na universidade, envolveu-se em uma relação amorosa intensamente, mas para ela "foi a pior coisa que já fez na vida" (EN3-Larissa), pois além de pedir dinheiro emprestado e não pagar, ele a podava de sair de casa, enquanto a traía e prometia casamento. Assim, Larissa perdeu a motivação para estudar, não concluiu o curso superior e abandonou a graduação. Larissa lamentou profundamente a sua não contratação em uma das empresas onde trabalhou como estagiária.

"Eu não sabia me comunicar, eu não conseguia, eu achava assim que a pessoa tinha que se virar como eu me virei, porque eu sabia das coisas, eu guardava as coisas e a última coisa que eu queria fazer era repassar o que eu sabia, por quê? Porque eu aprendia na marra, ninguém vinha me ensinar! E quando chegava um profissional novo, da minha área, eu achava um absurdo! Aí eu me trancava, me fechava, meu chefe me chamava, chamava atenção, vinha um $R H$ conversava comigo e eu não conseguia”. (EN5- Marina)

"Eu nunca tinha trabalhado com telemarketing, ai eu trabalhei pela primeira vez, teve um dia que eu entrei em surto lá no serviço. Aí num outro dia o rapaz pegou e tentou me agarrar lá, né? Ele assim... ele num me levou pra nenhum lugar, mas ele assim, me abraçou, né? Ele me puxou assim como se fosse pra algum outro lugar fora ali do ambiente do trabalho”. (EN3- Larissa)

"Eu fui lá entregar o atestado pra minha chefe, ela começou a falar um monte de coisas, falando que era um absurdo eu dar atestado, que eu não podia fazer aquilo, que era falta de Deus, que eu tava... que eu tinha que me recuperar logo, que ia prejudicar ela na gincana. [...] Eu chegava na sala da minha chefe, parecia que eu ia explodir, que eu ia assim, ter um treco! Meu coração acelerava, eu ficava ansiosa, assim... ficava com medo dela, entrava em pânico mesmo em relação a ela". (EN3Larissa) 
As histórias narradas expressam a expropriação do corpo, a exploração do trabalho e do cuidado das mulheres e diversas situações em que elas devem se submeter e obedecer, o que é comum na sociedade patriarcal. Nesse sentido, tanto nos casos de comportamento de resistência à expropriação quanto de ruptura psíquica (ataques de pânico, depressão, etc.), há punição pela não submissão e desobediência.

\section{Relações familiares}

Nesta categoria destacamos três subtemas - relações conjugais, maternagem (exercício do cuidado tido como materno), ascendentes e relação com os pais. Todos eles são permeados pelas violências: física, psicológica e sexual. As relações conjugais constituíram de maneira evidente parte das narrativas de três mulheres: Maria, Joana e Larissa. A experiência da conjugalidade vivida por essas mulheres foi narrada com emoção, choros e dificuldades em resgatar tantas memórias de sofrimento.

"Mexe muito com a minha cabeça, é um negócio que eu quero esquecer, quero esquecer, quero anular, mas não tem como, ele volta". (EN1- Maria)

"Eu tenho um passado muito sofrido e só eu que senti na pele é que sei, por mais que eu contar eu não consigo esclarecer pra você tudo que eu passei na minha vida". (EN2-Joana)

A história de Maria é marcada por violências e expropriação do próprio corpo. Ela iniciou a sua vida sexual aos 13 anos de idade, quando foi estuprada e forçada a abortar. Posteriormente, casou-se com um homem que acreditava ser ideal e desejado, mas descobriu se tratar de um agressor, extremamente violento e preconceituoso, o qual a mantinha como objeto sexual na relação conjugal, a espancou e cogitou terminar com o casamento após descobrir que ela não era virgem, mesmo que a virgindade não tivesse sido possível porque fora estuprada. Ainda sob ameaças, ele a manteve em cárcere privado e, após uma surra, ela sofreu o segundo aborto forçado, desta vez de gêmeos. Maria também era vítima de discriminação racial por parte da família do marido agressor. Ela decidiu denunciá-lo, mas voltou atrás e, novamente no convívio do agressor, foi espancada. Fica evidente, portanto, que, para ser feliz, ela se submete à apropriação do seu corpo e participa do ciclo das 
violências, assim se distanciando do desejo primário de ser amada, cuidada e cuidar de uma criança.

"A primeira surra que eu levei com quinze anos, [...]. eu me casei com ele sem ter relacionamento, tinha um namoro, aquele envolvimento tal, mas eu não tive coragem de contar que eu não era mais virgem. 'Tudo que eu queria na vida era ter casado com uma mulher cabaço! Eu fui enganado, eu fui um troxa"’.' (EN1- Maria)

"Eu sempre gostei de estudar! Mas ai eu me casei, era um homem beberrão, agressivo, não deixou eu estudar, não deixou eu trabalhar fora, não deixou eu fazer nada! Eu vivia assim é... à disposição dele, eu não sei bem colocar a palavra... como que eu vivia... subordinada! a ele, em todos os sentidos que a senhora possa imaginar!”. (EN1- Maria)

"Eu com quinze anos, ele ia embora trabalhar, ele me deixava trancada [...] e quando chegava geralmente era bêbado e me obrigando a fazer as coisas que eu não queria fazer! Começava pelos cabelos, puxando meus cabelos e jogando na parede, jogando na parede de costas, eu de frente pra ele, ele me socando minha cabeça na parede, então batia mais era a parte da cabeça. Esse corte aqui eu não me lembro, eu só sei que essa coisa me prejudicou muito a minha cabeça, eu sentia muita dor de cabeça, ele ficava me sacudindo, me sacudindo, aí, às vezes, eu perdia o sentido e outras vezes não, eu resistia! Mas eu ficava toda marcada, esse braço aqui quando saiu o osso, ficou exposto pra fora". (EN1-Maria)

"A família dele não me aceitava, [...], todos famílias brancas, e eu negra, preta, eu era a única negra da família... o pai dele não me aceitou, ele veio no casamento, me viu no casamento e não voltou mais, eu não vi mais a cara desse homem, e ele dizia que: 'Meu pai não gostou de você porque você é preta, você é negra! (desse jeito) E se eu contar também que você já não era mais moça aí que ele vai te odiar mesmo pro resto da vida",". (EN1-Maria)

"Ele foi me buscar no hospital já saiu de lá se maldizendo, pelo menos filhos eu tinha que ter: 'Nem pra ser mãe você não presta!' Sabia que foi ele que me bateu, eu perdi os bebês porque eu apanhei, eu quebrei o punho, ele me jogou do outro lado da cama de casal, eu caí por cima do braço, eu desmaiei, os bebês morreram na barriga". (EN1-Maria)

Após a separação do marido agressor, Maria casou-se novamente com um homem bom, cuidadoso e zeloso, um "salva-dor", como mencionado no estudo de Zanello, Fiuza e Costa (2015). No entanto, quando julgava que seria feliz, pois já estava grávida novamente, deparou-se com a impotência sexual do atual companheiro. Em choque, porque para ela sexo tem grande importância em um relacionamento, teve o terceiro aborto, desta vez atribuído à notícia reveladora, e mais uma vez interrompeu o seu sonho de maternar. Considera-se "mãe 
de filhos mortos" (EN1), o que sugere que o seu ideal de maternidade ainda está presente, o que a faz sofrer, sentir-se frustrada e paralisada diante da vida. Maria, na verdade, foi violentada e sofre pelos dois dispositivos mais importantes na nossa cultura ocidental: o materno e o amoroso.

Já para Joana e Larissa, o sofrimento pelo dispositivo amoroso emerge como um dos núcleos narrativos importantes. Joana salienta que se casou virgem, à época com 21 anos de idade, já era considerada velha. $\mathrm{O}$ marido era inicialmente visto por ela como alguém que a libertaria da prisão paterna, mas concluiu ter se casado com um carrasco. Joana era duplamente violentada, pois sofria a violência e tinha que silenciá-la. A relação conjugal foi marcada por poligamia do marido, cárcere privado, estupro no casamento, sendo a ela impostos o silêncio, o sofrimento e a punição.

"porque eu casei e meu marido me podô tudo e muito mais: 'Você não vai dar aula mais! Você só vai na casa da sua mãe quando eu deixar! Quem dita as regras aqui em casa sou eu e você só obedece, e se você não obedecer eu te mato!' [...], Quando casava você tava assinando que você era um traste daquele homem, que você era um objeto daquele homem”. (EN2-Joana)

"Com três anos ele matou meu irmão, foi um sofrimento que marcou minha vida pro resto..., num aceito, eu tenho dificuldade pra falar sobre esse assunto sabe? Tu não conta porque que nós tá aqui no (cidade onde estavam) não, se não eu te mato! Viu o quê que eu fiz com o seu irmão? Eu faço com você também! [...] eu num contava minha vida pra ninguém, eu num tive amiga que eu tivesse coragem de contar, sem ter medo de que elas contasse pro marido delas e eles comentasse com meu marido. E eu ainda fiquei vinte anos com esse homem". (EN2-Joana)

"Meu marido rumava o bico do revóver na minha... nas minhas narinas, no meu quexo e meu marido já enfiou o revólver dentro da minha vagina, cê acredita? E dizia pra mim que tudo aquilo que ele tava fazendo era pra mostrar pra mim o quanto ele me amava, quanto que ele me amava. Doía muito, era muita dor. Eu pegava infecção de urina, sabe?". (EN2-Joana)

"Meu marido não parecia um ser humano! Ele me pegô em cima da minha cama, ele me enforcô que eu dava de pé... eu batia de pé, sabe?”. (EN2-Joana)

O ciclo da violência também interfere na autoestima de Joana; como um jogo psicológico que se se utiliza do dispositivo amoroso, desqualifica o seu corpo e a sua sexualidade. No entanto, ela busca justificar a violência do marido, cuida dele e deixa de cuidar de si. Há, claramente, uma diferença nos papéis desempenhados na relação conjugal: uma mulher objeto sexual, sem protagonismo ou liberdade e um marido que ordena. Joana se 
submete, "veste" esse figurino de "mulher". Quando o marido a agrediu com o primeiro tapa, refere ter "gostado" das marcas que deixou: sua visibilidade e materialidade inegável trouxeram a validação de uma história de vida marcada pela violência, à qual se submetia e talvez fosse difícil de nomear. Como ela mesma referiu, agora era impossível esquecer e negar, porque as marcas eram uma presença insistente e viva. Com o decorrer do tempo e adoecida pela relação conjugal, ela implodiu - emagreceu, deprimiu, desejou morrer. Além de tudo, por contrair uma doença sexualmente transmissível do marido (DST-HPV), desenvolveu um câncer de útero e precisou retirá-lo.

"Eu não tinha busto, ele falava que eu não tinha maminha, eu tinha muito bumbum, eu era magrinha e tinha muito bumbum, ele dizia pra mim que eu parecia uma formiga tanajura... Então cê pensa complexo de entrar num quarto e tirar a roupa eu tinha! Ele falava pra mim que eu era feia, que se eu largasse ele ninguém me queria, que eu tava pegando o boi dele me querer". (EN2-Joana)

"Ele me deu um tapa na minha cara com tanta força que ficou sinal de quatro dedo no meu rosto. E eu fui lá cendi a luz e falei pra ele: 'Você nunca tinha me batido e você me bateu!' E tinha um espelho nos pé da cama, eu ficava olhando e apaixonei, sabe? Mas eu apaixonei tanto com aqueles quatro dedo que eu não queria que sarasse não! [...]". (EN2-Joana)

"Eu tava com uma doença venera que eu já tava tratando dela, só que eu não sabia que era tão grave! Essa doença que eu tava com ela tinha virado câncer. Eu tava enfrentando tudo isso e passando por um câncer. [...] eu cheguei só o couro e os ossos, ruim da cabeça, ficava só sentada, com dificuldade pra falar, de tanto passar fome, de tanto sofrimento. [...] E com um câncer que tava que eu tinha que tirar o útero, as trompa e os ovário [...] eu já tinha entregado os ponto, eu queria morrer". (EN2-Joana)

Na história de Larissa, a paixão por um homem casado foi narrada em meio a lágrimas, dor e tristeza. Ele, que lhe prometia casamento, a deixou em situação financeira bastante complicada. Durante esse período, Larissa omitiu da família todos os problemas por ela enfrentados - as dívidas e a poligamia do namorado. Ela já tinha uma fragilidade, como apontamos anteriormente, e deparou-se com mais esse sofrimento, que a deprimiu de tal forma que começou a ganhar peso, acabando por tentar o suicídio. O fato de não gostar do seu próprio corpo a afasta da possibilidade de encontrar um novo namorado e, ao que parece, sua relação era com a promessa de casamento e não com o homem real. Ela ofereceu, pelo dispositivo amoroso, inclusive aquilo que não dispunha e implodiu também. 
"Eu tive um namorado, ele era casado, eu não sabia. Eu fiquei cheia de dívida. Ele pediu pra comprar no cartão! Dei cheque pré-datado e tudo mais e eu ainda ia começar a pagar quando eu descobri. Ele mexeu muito comigo, ele acabou com minha vida. Por causa dele, aí eu comecei engordar. Eu não tenho vontade mais de me arrumar não! Eu não tenho vontade de me arrumar, minhas roupas todas elas foram perdidas, né? Já tentei emagrecer, já tentei fazer dieta, mas não consigo não”. (EN3- Larissa)

"Prometia, mas aí depois eu vi que ele num ia casar nada. Quando eu descobri tudo, que ele tava me traindo, ai eu vi que ele num ia casar”. (EN3- Larissa)

"Pra mim eu continuava entrando num precipício... não sei se eu juntei tudo de uma vez e explodi de uma vez só, ou se eu fui explodindo aos poucos e de repente eu caí assim no abismo, não via chão nenhum! Já tem nove anos que eu não tenho ninguém e nem quero". (EN3- Larissa)

Importante pontuarmos que três dessas mulheres sofreram estupro no casamento: Maria, Joana e Marina. Para Maria, o estupro experienciado na relação conjugal foi narrado na seguinte frase: “obrigando a fazer as coisas que eu não queria fazer! Com ele!” (EN1Maria). Já Joana e Marina nomearam claramente a violência sexual, o que não significa sua inviabilidade, pois, para o homem, a submissão sexual da mulher era algo natural, inclusive com lesão física, como nos casos de ambas.

"Eu tava com ligadura, meu marido chegou bêbado, me estuprô, rebentô meus ponto de perine, tudo no sexo, inda pegou o revólver e tirou meu filho da cama pra jogar ele pra cima e matar”. (EN2-Joana)

"Porque eu acho que eu era estuprada! Porque eu não queria de jeito nenhum! E ele forçava, ele segurava meus braços com força, e: 'Você vai, você vai...' E era um monte de hematomas que eu tinha no braço porque ele pegava pesado comigo. Aí quando eu não queria mesmo que eu recusava, que eu me trancava, muitas vezes eu me trancava no quarto! Era só eu abrir a porta, era um murro [...], era um prato quebrado, era tudo quebrado porque ele não aceitava! Porque homem é assim!". (EN5-Marina)

Outro subtema importante no contexto das relações familiares é a maternagem (exercício do cuidado materno), expresso na narrativa de Maria como aspecto que também a fez adoecer. Já nas histórias de Rosa e Marina emergiu como sensação de mal estar no papel de mãe. A “quebra psíquica” de Rosa decorreu da vivência de sofrimento durante o exercício 
da maternagem e pela ausência de cuidado materno quando criança, época em que sofria racismo e era explorada no trabalho doméstico pela avó, além de abandonada pela mãe biológica. Nesse contexto, a gravidez de Rosa a colocou em posição de fragilidade, pois não contava com rede de apoio ou ajuda do pai da criança, o qual era pobre. Por esses motivos, submeteu-se a morar com o marido na casa da sogra. Ao que parece, a vivência da maternidade prejudicou de maneira significativa a sua conjugalidade. Há, todavia, uma ambiguidade de sentimentos que a divide entre a rejeição ao exercício da maternidade e a culpa.

"No meu pré-natal eu queria ter ela, eu queria ver, eu gostava de ver ela mexendo na minha barriga, cuidei das roupinhas, fiz tudo no maior amor, no maior carinho, mas eu sozinha! Eu não tive companhia de ninguém, tanto é que se eu tivesse com vontade de comer alguma coisa eu ia sozinha comprar, não tive aquele 'paparico' do marido. Minha gravidez foi terrivel! Não pretendo nunca mais engravidar”. (EN4-Rosa)

"Eu não aguento não, vai ter que colocar (a filha) na creche, porque ela passando o dia todinho na creche pra mim é mais fácil porque eu só pego ela à noite e é mais fácil deu cuidar, porque eu não dou conta, eu tô cansada! Tava exausta, tava magrela igual um palito e ele lá deitado!’. (EN4-Rosa)

"Nunca suportava ela me abraçar! Aí eu não aguentei, ai eu tive que falar (para o marido) 'eu não tô suportando mais, eu não quero essa menina dentro de casa (chora), 'eu não gosto dessa menina, essa menina ela veio pra atrapalhar a minha vida!' A coitada da menina não fez nada comigo!'. (EN4-Rosa)

A dificuldade no exercício do cuidado materno é atribuída por Marina ao primeiro casamento, quando foi vítima de agressões físicas do marido, em função de não desejar manter relações sexuais com ele. Ao que parece, o fato de vivenciar uma gravidez de gêmeas, indesejada e de alto risco, colocou ainda mais sua saúde mental em risco. Em virtude de suas dificuldades em desempenhar o papel materno, este acabou sendo assumido pela avó materna, fato que se consumou após seu segundo casamento, quando suas filhas passaram a morar definitivamente com a avó. Com o segundo companheiro, houve uma nova gravidez e, mais uma vez, ela não se dispôs a exercer o papel materno, pactuando a doação da criança para o vizinho. 
"No dia que eu engravidei eu já falei pra mim mesma que eu não ia ter amor por elas! Eu chorei muito! Eu não queria! Eu queria um aborto natural, mas aí quando o Dr. falou assim: 'Olha a sua gestação é de alto risco; você tá esperando dois bebês!'. Eu fiquei maluca! Aí que eu chorei mesmo. A minha gestação foi muito difícil, muito complicada, era a minha família em cima de mim e eu sentindo dor o tempo todo. Que coisa mais chata, que coisa mais enjoada... Eu enjoei dele, da cara do pai delas, o meu marido, eu fiquei três meses na casa da minha mãe, eu não olhava na cara dele de jeito nenhum! Parece que quando eu olhava pra cara dele dava vontade de vomitar". (EN5-Marina)

"Quem fez tudo foi minha mãe! Desde o enxoval à minha roupa de uso gestacional foi minha mãe que organizou tudo pra mim, porque nem isso eu não queria, eu tinha repúdio assim da gestação, né? Por quê? Porque eu tinha repúdio dele! Minha mãe que ficava com elas, porque eu não tinha estrutura emocional pra ficar com as duas, eu não tinha estrutura! Quem mais cuidou delas foi minha mãe! Minha mãe parou a vida dela pra cuidar delas!". (EN5-Marina)

"Porque eu vejo hoje, tem mulher que já ama o filho dentro da barriga, que mal nasceu e nem viu a cara já faz um monte de coração na barriga, já compra logo um monte de roupa, eu nunca comprei roupa pra elas quando elas eram bebezinhas, eu não tinha esse prazer de comprar, eu não sei que sentimento é esse. Quando eu falava de não amor é porque realmente eu não sentia um amor assim de mãe pra filho, um amor maternal”. (EN5-Marina)

O último subtema da categoria relações familiares refere-se à relação dessas mulheres com os ascendentes e com os pais. Nas histórias de Joana, Larissa e Rosa, as relações familiares apareceram no passado, entretanto, para Marina, em um passado mais próximo. Joana foi cerceada em tudo - não podia namorar, vestir roupa curta ou cortar o cabelo, a "gente não aprendeu a ouvir "Sim”, nós crescemos só ouvindo "Não”. Larissa também teve uma relação com o pai marcada pela violência: "Eu apanhei, apanhei muito! Mas assim, num sei se fazia parte da criação do meu pai, mas da minha fez! E eu sinto até hoje, até hoje, mas assim, eu num quero guardar mágoa". "Eu fui a que mais apanhei em casa”. Já Rosa não conviveu com os pais, mas tem memórias de um pai violento, pois o presenciou matando duas pessoas a pauladas. Ela diz: "Eu criei medo dele", um medo que ainda perdura. Com a avó, como já apontado, a relação era de maus tratos e racismo.

Já para Marina, a relação com a mãe era de dependência afetiva. Durante o seu processo de adoecimento, foi ela quem assumiu várias de suas atribuições domésticas: organizava a dinâmica da casa, educava as netas, cozinhava, fazia compras e administrava o auxílio-doença da filha. Marina, por vezes, sentia-se desautorizada em seu papel materno, mas relata que era amparada pelos cuidados da mãe. No entanto, quando a mãe faleceu, viu-se 
obrigada a retomar o seu papel de esposa e mãe, assim precisando resgatar habilidades e esforços para novamente assumir as tarefas domésticas. Demonstra intenso sofrimento para superação do luto da mãe e sente culpa ao pensar que ela possa ter morrido para que ela, Marina, pudesse recomeçar a viver a sua própria vida. Narra que se sente sufocada por não conseguir reagir quando confrontada ou agredida, e que isso resulta em sua automutilação.

"Que tá partindo e que minha mãe partiu... Eu fiquei sem chão! E minhas filhas? Como é que eu vou cuidar de duas meninas sendo que eu estou incapacitada hoje pra amar? Porque eu não amo! Porque eu não amava, né? Eu não tinha sentimento por ninguém. E minha mãe foi embora, faleceu!'”. (EN5-Marina)

"Aí eu questiono Deus também sobre isso: 'Por que que Deus tirou minha mãe? Pra eu viver? Mas por que que teve que penalizar ela? Não podia me tirar de campo ao invés de tirar ela?'. É porque eu era muito dependente, muito! Era uma coisa assim... Eu dormia na casa dela, quantas vezes eu deixava meu marido em casa e ia dormir lá na casa da minha mãe com minhas meninas...". (EN5-Marina)

"Então, esses pensamentos que eu tenho de não conseguir me expressar e essas revoltas que me dá dentro de mim, que faz com que eu me machuque, por exemplo, não consigo resolver minhas coisas que tem que resolver...". (EN5-Marina)

\section{CONSIDERAÇÕES FINAIS}

Durante as entrevistas, obtivemos narrativas autobiográficas por meio das quais foi possível acessar situações dolorosas e estigmatizadoras vivenciadas por mulheres. São relatos íntimos que expressam intenso sofrimento e versam sobre episódios de dor psíquica, cenários e personagens que contribuíram para essa vivência dolorosa. Muitas delas eram pobres, não frequentavam a escola formal e dedicavam-se basicamente aos cuidados domésticos. As narrativas das mulheres trouxeram especificidades de gênero, vivenciadas ao longo de sua trajetória de vida, sobre o trabalho como vulnerabilidade atravessada pelo gênero e as relações familiares. No que concerne a inserção do trabalho na vida dessas mulheres, o sofrimento psíquico é evidente, frente à invisibilidade, ao não reconhecimento, à exploração e expropriação do trabalho (doméstico e ou formal). Aspecto curioso e bastante presente nos discursos foi a busca pela emancipação por meio da escolaridade, como forma de "ser alguém na vida". A meta de estudar emergiu aliada à expectativa de superar precárias condições de 
trabalho. No entanto, para a maioria, essas expectativas não se realizaram e, atualmente, essas mulheres não apresentam projetos e ou expectativas futuras.

Já as relações familiares, em virtude da forma como ocorrem na conjugalidade, são marcadas também pela expropriação do próprio corpo e pela questão da violência. No que tange à maternidade, evidenciou-se que não conseguir exercer plenamente este papel (não só por condições externas, mas por falta de desejo e amor) configura-se como um fator de vulnerabilidade para as mulheres. Após tantas dores vivenciadas no trabalho e nas relações familiares, elas encontraram na religiosidade um dos caminhos para alívio e busca de respostas para a dor psíquica.

Como se pode perceber, destacou-se na fala dessas mulheres o modo como os eventos de suas vidas narrados como expressão de si são atravessados pelo gênero: na subjugação sexual, no tipo de papel exercido em conjugalidades predominantemente patriarcais, na (impossibilidade do exercício da) maternidade, no trabalho doméstico sem reconhecimento. Fica em suspenso a pergunta: de que políticas públicas precisamos para além da psiquiatrização?

\section{REFERÊNCIAS}

ANDRADE, Ana Paula Müller de. (2010). O gênero no movimento da reforma psiquiátrica. In: MALUF, Sônia Weidner; TORNQUIST, Carmem Susana (Orgs.). Gênero, saúde e aflição: abordagens antropológicas. Florianópolis: Letras Contemporâneas. p. 273-293.

AREND, Silvia Fávero (2013). Meninas: trabalho, escola e lazer. In: PINSKY, Carla Bassanezi; PEDRO, Joana Maria. Nova história das mulheres no Brasil. São Paulo: Contexto, 2013.

BASAGLIA, Franca. (1987). Mujer, locura y sociedad. México: Universidad Autónoma de Puebla.

BRANDÃO, Thaís Oliveira; GERMANDO, Idilva Maria Pires. (2009). Experiência, memória e sofrimento em narrativas autobiográficas de mulheres. Psicologia \& Sociedade, v. 21, n. 1.

CAMPOS, Ioneide de Oliveira; ZANELLO, Valeska. (Submetido). Saúde Mental e Gênero: o sofrimento psíquico, diagnósticos e a invisibilidades das violências.

CAMPOS, Ioneide de Oliveira; ZANELLO, Valeska; RAMALHO, W. (Submetido). Saúde mental e gênero: o perfil sociodemográfico de pacientes em um Centro de Atenção Psicossocial. 
CARVALHO, Lúcia de Fátima; DIMENSTEIN, Magda. (2004). O modelo de atenção à saúde e o uso de ansiolíticos entre mulheres. Estudos de Psicologia, v. 9, n. 1, p.121-129.

DENZIN, Norman K.; LINCOLN, Yvonna S. (2006). O planejamento da pesquisa qualitativa: teorias e abordagens. Porto Alegre: Artmed.

ENGEL, Magali. (2007). Psiquiatria e feminilidade. In: DEL PRIORE, Mary (Org.). História das mulheres no Brasil. São Paulo: Contexto. p. 323-360.

FLICK, Uwe. (2009). Introdução a pesquisa qualitativa. Porto Alegre: Artmed.

GARCIA, Carla Cristina. (1995). Ovelhas na névoa: um estudo sobre as mulheres e a loucura. Rio de Janeiro: Record; Rosa dos Tempos.

JOVCHELOVITCH, Sandra; BAUER, Martin W. (2002). Entrevista narrativa. In: BAUER, Martin W.; GASKELL, George. Pesquisa qualitativa com texto, imagem e som: um manual prático. Petrópolis: Vozes. p. 90-113.

MINAYO, Maria Cecília de Souza. (2006). O desafio do conhecimento: pesquisa qualitativa em saúde. 9. ed. São Paulo: Hucitec.

MINAYO, Maria Cecília de Souza. (2004). Ciência, técnica e arte: o desafio da pesquisa social. In: MINAYO, Maria Cecília de Souza; DESLANDES. Suely Ferreira; CRUZ NETO, Otávio; GOMES, Romeu. (Orgs.). Pesquisa Social: teoria, método e criatividade. 23. ed. Rio de Janeiro; Petrópolis: Vozes. p. 9-29.

MINAYO, Maria Cecília de Souza. (2006). O desafio do conhecimento: pesquisa qualitativa em saúde. 9. ed. São Paulo: Hucitec.

NOVAES, Joana Vilhena. (2013). O intolerável peso da feiura: sobre as mulheres e seus corpos. Rio de Janeiro: Ed.PUC-Rio; Garamond..

PERROT, Michelle. (2013). Minha história das mulheres. São Paulo: Contexto.

PHILLIPS, K. A; FIRST, Michael B. (2008). Introdução. In: NARROW, William E. et al. (Orgs.). Gênero e idade: considerações no diagnóstico psiquiátrico. Agenda de pesquisa para DSM V. São Paulo: Roca.

ROSENTHAL, Gabriele. (2014). Pesquisa social interpretativa: uma introdução. Porto Alegre: EDIPUCRS.

SANT’ANNA, Denise Bernuzzi de. (2014). A história da beleza no Brasil. São Paulo: Contexto.

SANTOS, Anna Maria Corbi Caldas dos. (2009). Articular saúde mental e relações de gênero: dar voz aos sujeitos silenciados. Ciência e Saúde Coletiva, v. 14, n. 4, p. 1177-1182.

Disponível em: <http://dx.doi.org/10.1590/S1413-81232009000400023>. Acesso em: 22 abr. 2015.

SWAIN, Tania Navarro. (2006). Entre a vida e a morte, o sexo. Labrys: estudos feministas, v. 10. Disponível em: <http://www.intervencoesfeministas.mpbnet.com.br/textos/taniaentre_a_vida_ea_morte.pdf $>$. Acesso em: 23 set. 2015. 
ZANELLO, Valeska. (no prelo). Saúde mental, gênero e dispositivos. In: Dimenstein, Magda (Org). Condições de vida e saúde mental em assentamentos rurais. São Paulo: Intermeios Cultural, (ano previsto de publicação: 2016).

ZANELLO, Valeska; FIUZA, Gabriela; COSTA, Humberto Soares. (2015). Facetas gendradas do sofrimento psíquico. Fractal: Revista de Psicologia, v. 27, n. 3.

ZANELLO, Valeska. (2014). A saúde mental sob viés de gênero, da semiologia e da interpretação diagnóstica. In: ZANELLO, Valeska; ANDRADE, Ana Paula Müller de. Saúde mental e gênero: diálogos, práticas e interdisciplinaridade. Curitiba: Appris.

ZANELLO, Valeska; ROMERO, Ana Carolina. (2012).'Vagabundo ou vagabunda? Xingamentos e relações de genero". Labrys: estudos feministas, v. 22. Disponível em: <http://www.labrys.net.br/labrys22/libre/valeskapt.htm>. Acesso em: 22 fev. 2016.

ZANELLO, Valeska; SILVA, René Marc Costa e. (2012). Saúde mental, gênero e violência estrutural. Revista Bioética, Brasília, v. 20, n. 2, p. 267-279, 2012.

ZANELLO, Valeska; BUKOWITZ, Bruna. (2011). Loucura e cultura: uma escuta das relações de gênero nas falas de pacientes psiquiatrizados. Labrys: estudos feministas, v. 20. Disponível em: <http://www.labrys.net.br/labrys20/brasil/valeska.htm>. Acesso em: 22 fev. 2016.

ZANELLO, Valeska; FONSECA, Gabriela Macedo Pinheiro da; ROMERO, Ana Carolina. (2011). Entrevistas de evolução psiquiátricas: entre a "Doença Mental" e a medicalização. Mental, v. 9, n. 17, p. 621-640.

ZANELLO, Valeska; GOMES, Tatiana. (2011). Xingamentos masculinos: a falência da virilidade e da produtividade. Caderno Espaço Feminino (UFU), v. 23, n. 1/2, p. 265-280. 


\section{CONSIDERAÇÕES FINAIS}

Com o objetivo principal de realizar uma leitura do sofrimento psíquico sob o enfoque das relações de gênero elaboramos um levantamento sociodemográfico e epidemiológico dos usuários/as atendidos no período de 2012 a 2013, em um Centro de Atenção Psicossocial II localizado em Brasília, tendo como base 234 prontuários.

Esta tese é composta de quatro artigos, os quais abordaram aspectos importantes sobre a saúde mental e gênero nesse serviço e podem contribuir para ampla reflexão sobre as práticas de saúde mental adotadas no Brasil.

Como alguns dos principais aspectos pontuados nos artigos, evidenciamos, primeiramente, a expressiva população de mulheres no CAPS II, cenário desta pesquisa, o que corrobora outros estudos brasileiros que apontaram as mulheres como as principais frequentadoras de serviços de saúde (TRAVASSOS et al., 2002; TELLES FILHO et al., 2011). O perfil populacional revelou características comuns entre os sexos - por exemplo, baixos níveis de renda e escolarização - e ocupações predominantemente baseadas nas diferenças de gênero. Notamos ainda a presença de desigualdades sociais e precariedade da categoria "trabalho" na vida dos usuários/as, tanto na inserção do trabalho formal quanto informal.

Também foi observada ausência de informações nas fichas de acolhimento analisadas, o que permite inferir que a maioria dos profissionais apresenta dificuldades em considerar determinados aspectos da vida do usuário/a significativos para a compreensão do sofrimento psíquico. Nesse sentido, educação permanente deve ser oferecida aos membros da equipe, por se tratar de importante ferramenta para garantir o acolhimento das demandas de mulheres e homens, em uma perspectiva de compreensão dos processos sociais integrados ao cotidiano das pessoas em sofrimento.

A leitura minuciosa dos 234 prontuários também evidenciou claras diferenças entre as condições das mulheres e as dos homens. Entre os prontuários, 169 eram de mulheres, a maioria com vivência de conflitos com a mãe, pai e/ou ascendentes (desentendimentos, perdas e maus tratos) e questões relacionadas à maternidade (dificuldade no exercício do cuidado 
materno, nascimento ou morte de um filho), relações conjugais (divórcio, separação, brigas, tentativas de suicídio, violências), vida laboral prejudicada e sobrecarga no papel de cuidadora de outros e da casa. Já nos prontuários dos homens, esses aspectos estiveram pouco presentes, notando-se escassos relatos sobre conflitos familiares, relação conjugal, relacionamento com os filhos e com a mãe.

Os dados levantados nesse CAPS apontaram ainda para uma psiquiatrização indevida das mulheres. Se os homens apresentaram quadros diagnósticos mais graves, tais como psicoses e retardo mental, as mulheres vivenciaram transtornos de depressão e ansiedade, caracterizados como Transtornos Mentais Comuns, altamente correlacionados na literatura (LUDEMIR, 2000; 2005; 2008; SANTANA, 1987) tanto com o perfil sociodemográfico quanto às situações de violência por elas vividas.

Tais dados, associados ao levantamento do perfil sociodemográfico e à análise dos dados dos prontuários, apontaram para a medicalização e psiquiatrização da vida, sobretudo no caso das mulheres, cuja presença em episódios de violência chegou a 32,54\%. No entanto, os sintomas por elas apresentados são compreendidos de um modo que não estabelece possível relação entre o transtorno, a estrutura socioeconômica, as relações de gênero e o histórico da violência e, portanto, são apenas diagnosticados e medicalizados, visando à sua supressão.

Por último, as situações dolorosas e estigmatizadoras vivenciadas por mulheres foram ouvidas, e suas falas revelaram o modo como os eventos de suas vidas narrados como expressão de si são atravessados pelo gênero: na subjugação sexual, no tipo de papel exercido em conjugalidades predominantemente patriarcais, na maternidade (impossibilidade de exercê-la) e no trabalho doméstico sem reconhecimento. Ter uma escuta que qualifique esse sofrimento o torna visível, desnaturaliza os papéis de gênero, tão arraigados no social e, sobretudo, permite que saiam do silenciamento, do silêncio comum das mulheres, como aborda Perrot (2005).

Do ponto de vista político e social, apreendemos que, apesar das discussões sobre a assistência psiquiátrica terem avançado bastante no Brasil, nosso atual modelo de atenção psicossocial pode não possibilitar um acolhimento adequado às mulheres em geral, caso não qualifique as especificidades de gênero e suas interseccionalidades. Logo, faz-se premente a definição de uma agenda específica sobre gênero e saúde mental, que avance além da relação entre saúde da mulher, direitos sexuais e reprodutivos, como também investimentos em 
políticas públicas transversais, como forma de subsidiar a atual Política de Saúde Mental Brasileira.

Repensar a reforma psiquiátrica sob esta ótica implica trazer, dos bastidores para a cena, a saúde mental e as relações de gênero, o que requer transformações nas esferas da cultura, das leis, das práticas políticas. Somente assim será possível conceber o sofrimento psíquico como decorrente também de diversidades na sociedade, das diferenças sexuais, dos preconceitos e estereótipos presentes nas práticas sociais cotidianas. 


\section{REFERÊNCIAS}

LUDERMIR, Ana Bernarda. (2000). Inserção produtiva, gênero e saúde mental. Cadernos de Saúde Pública, v. 16, n. 3, p. 647-659. Disponível em: <http://dx.doi.org/10.1590/S0102311X2000000300013>. Acesso em: 10 jun. 2015.

LUDERMIR, Ana Bernarda. (2005). Associação dos transtornos mentais comuns com a informalidade das relações de trabalho. Jornal Brasileiro de Psiquiatria, v. 54, n. 2, p. 198204. Disponível em: 〈http://www.saudeetrabalho.com.br/download/informal-ludermir.pdf>. Acesso em: 18 jun. 2015.

LUDERMIR, Ana Bernarda. (2008). Desigualdades de classe e gênero e saúde mental nas cidades. Physis, v. 18, n. 3, p. 451-467. Disponível em: <http://www.scielo.br/ scielo.php?script=sci_arttext\&pid=S0103-73312008000300005\&lng=en\&nrm=iso $>$. Acesso em: 22 jun. 2015.

PERROT, Michelle (2005). As mulheres ou os silêncios da história. Bauru: EDUSC, 2005.

SANTANA, Vilma Sousa et al. (1997). Informal jobs: another occupational hazard for woman's mental health. International Journal of Epidemiology, England, v. 26, n. 6, p. 12361242. Disponível em: <http://ije.oxfordjournals.org/content/26/6/1236.full.pdf>. Acesso em: 10 jun. 2015.

TELLES FILHO, Paulo Celso Prado et al. (2011). Utilização de benzodiazepínicos por idosos de uma estratégia de saúde da família: implicações para enfermagem. Escola Anna Nery, v. 15, n. 3, p. 581-586. Disponível em:

<http://www.revistaenfermagem.eean.edu.br/detalhe_artigo.asp?id=682>. Acesso em: 22 jun. 2015 .

TRAVASSOS, Cláudia et al. (2002). Utilização dos serviços de saúde no Brasil: gênero, características familiares e condição social. Revista Panamericana de Salud Publica, v. 11, n. 5-6, p. 365-373. Disponível em: 〈http://dx.doi.org/10.1590/S1020-49892002000500011>. Acesso em: 10 jun. 2015. 
ANEXO A - PARECER DE APROVAÇÃO DO CEP IH/UNB

\section{INSTITUTO DE CIENCIAS HUMANAS / UNIVERSIDADE DE BRASÍLIA / CAMPUS}

\section{PARECER CONSUBSTANCIADO DO CEP}

\section{DADOS DO PROJETO DE PESQUISA}

Título da Pesquisa: Implicaçōes entre gênero e saúde mental: uma leitura dos diagnósticos e do sofrimento dos Usuários do CAPS Taguatinga

Pesquisador: Ioneide de Oliveira Campos

Área Temática:

Versão: 2

CAAE: $30378314,8,0000,5540$

Instituição Proponente: Instituto de Psicologia -UNB

Patrocinador Principal: Financiamento Próprio

\section{DADOS DO PARECER}

Número do Parecer: 692.165

Data da Relatoria: 30/05/2014

Apresentaçăo do Projeto:

O projeto propoe pesquisa de cunho quantitativo e qualitativo sobre a relacoes de genero e saude mental no ambito do Centro de Atencao Psicossocial - CAPS Taguatinga-DF. Para isso serao considerados sintomas, diagnosticos e vivencias de usuarias e usuarios do Centros de Atencao Psicossocial II de Taguatinga sob a perspectiva de genero na vida cotidiana dos usuarios e usuarias desse servico.

\section{Objetivo da Pesquisa:}

Geral: Comparar os sintomas, diagnosticos e vivencias de usuarias e usuarios do Centros de Atencao Psicossocial II de Taguatinga sob a perspectiva de genero. Especificos:

Caracterizar o Centro de Atencao Psicossocial de Taguatinga: estrutura organizacional e a dinamica da atencao em saude mental; Levantar o percentual de mulheres e homens;

\section{Avaliaçăo dos Riscos e Beneficios:}

O projeto considera a possibilidade de riscos na pesquisa no que se refere a exposicao dos pacientes a eventuais experiencias de sofrimento rememoradas. Caso isso ocorra, considera-se que serao tomadas medidas para buscar minimizar-se essas situacoes, inclusive prestando assistencia psicologica aos pacientes caso necessario.

Quanto aos beneficios, acredita-se que os resultados das pesquisas ao serem compartilhados com

Endereço: CAMPUS UNIVERSITARIO DARCY RIBEIRO -ICC ¿ALA NORTE ¿ MEZANINO ¿SALA B1 ¿ 606 (MINHOCÅO Bairro: ASA NORTE

UF: DF Municipio: BRASILIA

Telefone: (61)3307-2760 CEP: $70,910-900$ 


\section{INSTITUTO DE CIENCIAS \\ HUMANAS / UNIVERSIDADE Slotoformo DE BRASILIA / CAMPUS}

Contmuapos do Pavoer: the.16s

as agertes do CAPS poderao contribuir para a meheris do servico prestade acs pacientes, sobretudo no que se refere a uma comoreensao ma's ampla dos implicativos no acelimento referentes a saude mertal $\mathrm{c}$ genero.

Comentários o Considoraçōes sobro a Pesquisa:

O projeto apresenta uma discussae acerca do desenvolvimento historico de politicas voladas a saude mental no Brasil ate a criacao dos CAPS para logo em seguida propor uma pesquisa de dupla entrada qualitativa e quantitativa. Em que serae andisados os prantuarios des pacientes do CAPS, nesse contexto qualquer informacao que possa identificar os paciertes serao descartadas, Em seguida serao realizadas entrevistas semi estruturadas cam um numero reduzido de pacientes.

Consideraçóes sobre os Termos de apresentaçáo obrigatória:

Os temos forma apresentados de scordo com ss especificacoes do CEPAH.

Recomendaçōos:

Conc|usbes ou Pendènclas o Lista de Inadequaçóc:

O projeto especificou onde serso reslizadas as entrevistas, assim come atualizou seu cronograma $e$ informou sobre quem fara o primeiro contato oum as pacientes,

Situaçăo do Parecer:

Aprovade

Necessita Apreciaçăo da CONEP:

N⿶̊ำ

Consideraçōes Finais a critério do CEP:

BRASILIA, 19 de Junho de 2014

Assinado por:

Soraya Flelscher

(Ceordeaader)

Telolene: [61)392702705 


\title{
ANEXO B - TERMO DE CONSENTIMENTO LIVRE E ESCLARECIDO (TCLE)
}

Você está sendo convidada a participar da pesquisa Implicações entre gênero e saúde mental: uma leitura dos diagnósticos e do sofrimento dos Usuários do CAPS Taguatinga, de responsabilidade de Ioneide de Oliveira Campos, aluna de doutorado da Universidade de Brasília. O objetivo desta pesquisa é comparar os sintomas, diagnósticos e vivências de usuárias e usuários do Centros de Atenção Psicossocial II de Taguatinga. Assim, gostaria de consultá-lo(a) sobre seu interesse e disponibilidade de cooperar com a pesquisa.

Você receberá todos os esclarecimentos necessários antes, durante e após a finalização da pesquisa, e lhe asseguro que o seu nome não será divulgado, sendo mantido o mais rigoroso sigilo mediante a omissão total de informações que permitam identificá-la. Os dados provenientes de sua participação na pesquisa, tais como questionários, entrevistas, fitas de gravação ou filmagem, ficarão sob a guarda do pesquisador responsável pela pesquisa.

A coleta de dados será realizada por meio de uma entrevista, que ocorrerá no próprio CAPS, em dia e horário de comparecimento do usuário, com duração variável de $2 \mathrm{~h}$ a $4 \mathrm{~h}$, em uma sala reservada para tal, na qual permanecerão apenas o entrevistador e entrevistado. Sua participação na pesquisa não implica em nenhum risco.

Sua participação é voluntária e livre de qualquer remuneração ou benefício. Você é livre para recusar-se a participar, retirar seu consentimento ou interromper sua participação a qualquer momento. A recusa em participar não irá acarretar qualquer penalidade ou perda de benefícios.

Se você tiver qualquer dúvida em relação à pesquisa, você pode me contatar através do telefone (61) 81851218 ou pelo e-mail ioncampos@hotmail.com A equipe de pesquisa garante que os resultados do estudo serão devolvidos aos participantes por meio de reunião com a equipe técnica, podendo ser publicados posteriormente na comunidade científica.

Este projeto foi revisado e aprovado pelo Comitê de Ética em Pesquisa do Instituto de Ciências Humanas da Universidade de Brasília - CEP/IH. As informações com relação à assinatura do TCLE ou os direitos do sujeito da pesquisa podem ser obtidos através do e-mail do CEP/IH cep_ih@unb.br.

Este documento foi elaborado em duas vias, uma ficará com a pesquisadora responsável pela pesquisa e a outra com a senhora.

Brasília, de de 2015.

\author{
Assinatura do (a) participante
}

Assinatura do (a) pesquisador (a) 


\section{ANEXO C - ROTEIRO SEMIESTRUTURADO DE ENTREVISTA}

1. Conte um pouco sobre a sua vida.

2. Desde quando frequenta o CAPS?

3. Já frequentou outros serviços de saúde mental?

4. O que aconteceu na época?

5. Fale sobre os seus projetos de vida. 